$1-1-2014$

\title{
Caregiver Payments and the Obligation to Give Care or Share
}

Merle H. Weiner

Follow this and additional works at: https://digitalcommons.law.villanova.edu/vlr

Part of the Family Law Commons

\section{Recommended Citation}

Merle H. Weiner, Caregiver Payments and the Obligation to Give Care or Share, 59 Vill. L. Rev. 135 (2014). Available at: https://digitalcommons.law.villanova.edu/vlr/vol59/iss1/4

This Article is brought to you for free and open access by Villanova University Charles Widger School of Law Digital Repository. It has been accepted for inclusion in Villanova Law Review by an authorized editor of Villanova University Charles Widger School of Law Digital Repository. 


\title{
CAREGIVER PAYMENTS AND THE OBLIGATION TO GIVE CARE OR SHARE
}

\author{
Merle H. Weiner*
}

\section{INTRODUCTION}

$\mathrm{T}$ HE law disserves parents who are the primary caregivers for their children. Some parents perform a disproportionate amount of caregiving labor, but receive little or nothing in return from the other parent. In order to be eligible for any sort of remedy for this freeloading, the law generally requires that the caregiver was married and performed the disproportionate caregiving during the marriage. Unmarried caregivers are left with few, if any, remedies, and divorcing caregivers find that alimony (or, as it is sometimes called today, "spousal support" or "maintenance") fails to address adequately their post-divorce caregiving.

This article argues that parents should have a legal obligation to share fairly the caregiving responsibility for their children, regardless of whether the parents are married, unmarried, separated, or divorced. Every parent should be obligated "to give care or share," i.e., to pay compensation to the other parent for any disproportionate and unfair caregiving that occurs. This general obligation should be imposed without delay, despite the fact that the legal solution will be untidy. A broad mandate that a court make "fair" a breach of the obligation to give care or share will allow courts to determine immediately, on a case-by-case basis, the appropriate remedy for each caregiver's particular situation. A broad mandate will also lay the groundwork for improvements to a complicated area of the law. The claimants' awards and judicial assessments of "unfairness" can inform the development of future adjudication guidelines.

This article proceeds in six parts. First, it explains why a legal remedy is needed for some disproportionate caregiving. It isolates disproportionate and unfair caregiving as the problem, and suggests that freeloading (by one parent off of the caregiving labor of the other parent) constitutes the unfairness. Second, the article argues that all caregivers, not just married caregivers, should have a remedy for freeloading because "mooching" is wrong regardless of the parents' marital status. If anything, the rise of

* Philip H. Knight Professor of Law, University of Oregon School of Law. Thanks go to Professor Cynthia Starnes for her helpful comments on a draft of this article. I also appreciate the comments I received from attendees at the International Society of Family Law's North American Conference in Brooklyn in June 2013. Thanks as well to Professor Charles Kindregan, who pointed me in a useful direction regarding Massachusetts law, and Professor Carol Rogerson, who pointed me in a useful direction regarding Canadian law. Of course, I owe a debt of gratitude-as always-to my talented research assistants, including Kelsey Fleharty, Chris Gray, Stephanie Hyatt, Marie Phillips, and Ryan Tarter. 
unwed childbearing and the extreme freeloading that unmarried caregivers sometimes experience suggest that a legal remedy is essential. Third, the article describes the inadequacy of the existing law for divorcing caregivers, that is, even for those caregivers who are thought "deserving."

The second half of the article then discusses ways in which the law might change to better redress the unfairness experienced by caregivers. The fourth part examines contemporary reform proposals, including those by the American Law Institute and several scholars. These proposals, if adopted, would move the law in the right direction, but they all fail as complete solutions because they exclude certain caregivers and rely on rigid formulas or theories. The article's fifth part proposes a general legal obligation applicable to all parents, and argues against ossifying the law's development by selecting now a particular approach or theory to govern the claims. Rather, courts should assess "unfairness" by examining the relevant facts and then use the full range of available theories from the alimony context to craft the most appropriate remedy for each case. Finally, the sixth part of the article explores the disadvantages that might arise if this proposal were adopted.

This article is one part of a much larger project by this author that focuses on the development of a legal status for parents of the same child. Cambridge University Press will publish that longer work, entitled The Parent-Partner Status in American Family Law. That book details several other inter se legal obligations that arguably should also exist between parents. If adopted, the proposed obligations together would create a new legal status for parents and further a reconceptualization of American family law around parenthood. Consequently, this article's proposal for caregiver compensation is best understood as one possible component of a new legal status. The book contains several justifications for the new status that are not reproduced here, but those justifications also support this particular proposal. I commend the forthcoming book to readers interested in a more complete picture of the role that caregiver compensation might play in the development of a new status and the benefits that such a status would provide.

\section{Freeloading off of the Caregiver}

"Caregivers" are defined here as parents, whether married, divorced, or unmarried, who perform a disproportionate amount of caregiving for their children. Parents rarely split caregiving labor in half. Caregivers often experience economic and other disadvantages from performing a disproportionate amount of this work, especially when they are not in a sharing relationship such as marriage. However, without more, neither the disproportionality of the caregiving nor the hardship associated with disproportionate caregiving justifies the imposition of a legal obligation on the other parent to redress the situation. Rather, a legal remedy is 
appropriate because some caregivers' disproportionate burden is "unfair," or more particularly, the other parent acts "wrongfully." 1 Wrongful behavior exists when a parent unilaterally retains the benefit of the caregiver's labor without giving anything of sufficient value to the caregiver in exchange, even though caregiving for their child is their shared responsibility. This type of wrongful behavior is typically called "freeloading," ${ }^{2}$ and unfortunately, it is widespread among parents.

\section{A. Freeloading Patterns}

The type of behavior that causes concern falls into some pretty identifiable patterns. Sometimes one parent is freeloading off of the other parent by allowing her ${ }^{3}$ to perform all of the caregiving and giving her nothing in return. The most egregious situation is when one parent totally abdicates his responsibility and leaves the other parent with no choice at all about how to share work or resources. The abdicating parent gives the caregiving parent nothing for her efforts and may not even provide child support, but instead goes off to do his own thing. The caregiving parent must then struggle to provide for the child's material and nonmaterial needs alone. A similar lopsidedness can arise when a court awards primary custody to one parent while the other parent is free of most caregiving obligations, and the court provides the caregiver with no compensation for her future caregiving work.

Another unfair pattern arises when the parties have an agreement about the sharing of caregiving and market labor, but the agreement is repugnant in some way that makes the arrangement unjust. Imagine, for example, that the caregiver agrees to do all the caregiving in exchange for the market worker's promise not to beat her. The market worker already has that legal obligation, so he is giving her nothing in exchange for the caregiving. ${ }^{4}$ In addition, the very nature of the exchange is offensive to

1. See June Carbone, The Futility of Coherence: The ALI's Principles of the Law, 4 J.L. \& FAm. Stud. 43, 65 (2002) (citing Margaret F. Brinig \& June Carbone, The Reliance Interest in Marriage and Divorce, 62 Tul. L. Rev. 855, 878-89 (1988)).

2. Norman E. Bowie has described well how freeloading violates Kant's first categorical imperative, a variation of the golden rule. See Norman E. Bowie, Kantian Ethical Thought, in The Ethics of Human Resources and Industrial RelaTiOns 61, 62-64 (John W. Budd \& James G. Scoville eds., 2005). The other moral and policy bases for a caregiver payment can be found in Merle Weiner, The Parent-Partner Status in American Family Law (Cambridge University Press) (forthcoming).

3. The female pronoun is used for the caregiver and the male pronoun is used for the market worker, as these gendered patterns persist. Of course, the gender of the caregiver and market worker could be reversed, or the roles could be shared, or the pronouns could be the same for the caregiver and market worker in same-sex couples, but for simplicity's sake, the stereotypical genders are assigned to these roles. [Editor's Note: The Villanova Law Review requires the use of gender-neutral language, but has permitted the author's use of gender-specific language for the purposes of this article.]

4. Contract law would classify such a contract as lacking "consideration." The absence of consideration is not always determinative of "unfairness." For example, 
modern sensibilities. Or, consider a situation in which the parties' agreement violates public policy. The parties agree, for example, that the mother will do all of the caregiving in exchange for the father's promise not to contest custody if the parties ever divorce. Such a contract would be unenforceable because it violates the public's interest in having a court determine custody based upon the best interests of the child. ${ }^{5}$ The caregiver who acts for years on the assumption that she would get something in exchange for her efforts, experiences an unfairness when the benefit of her bargain disappears, even for a good reason like public policy.

Unfairness can also exist when one party breaches an otherwise unobjectionable agreement. Imagine, for example, that the parties agree that the mother will provide caregiving and the father will work in the market, and both parties will share the father's income. If the father withholds his income from the mother, he would breach their agreement and would be acting unfairly. Similarly, spouses may agree that the mother will stay home and watch the child until the child is ten years old and the father will support the family financially. If the father refuses to support the mother because they divorce, but the child is only five years old, the father is treating the mother unfairly. ${ }^{6}$

Some people might dispute whether any unfairness exists in the last example because, they would claim, the couple's original agreement no longer governs their relationship once they divorce. After all, both parties assumed that they would be romantically involved forever, or at least until the child turned ten years old, and that assumption turned out to be incorrect. Sometimes-but not always-a party can be released from a contract when a fundamental assumption underlying the contract dramatically changes. ${ }^{7}$

But this reasoning is questionable. First, it assumes that the parents' agreement about the caregiving and related compensation is an enforceable agreement, subject to the normal rules of contracting. However, it is not. Courts will not enforce contracts between spouses about such fundamental family arrangements. Sometimes a statute precludes it. ${ }^{8}$ Other times, courts employ common law contract doctrine and find a lack of

a married father might support his family in exchange for the mother's caregiving. This arrangement might also lack consideration, but it is not unfair.

5. One might label this contract unconscionable. Unconscionable can mean the contract tries to eliminate "fundamental duties otherwise imposed by the law," or "seek [s] to negate the reasonable expectations of the nondrafting party," or the main terms are "unreasonably and unexpectedly harsh." 8 SAmuel Williston \& Richard A. Lord, A Treatise on the Law of Contracts $\$ 18: 10$ (4th ed. 2012).

6. See Jana B. Singer, Alimony and Efficiency: The Gendered Costs and Benefits of the Economic Justification for Alimony, 82 GEO. L.J. 2423, 2431 (1994).

7. See 17A Am. Jur. 2D Contracts $\$ 651$ (2012) (discussing contract that is "frustrated because of changed conditions" not due to party's fault, and where parties did not assume that condition would ever occur).

8. See, e.g., Miss. Code Ann. § 93-3-7 (2013) ("Husband and wife shall not contract with each other, so as to entitle the one to claim or receive any compensation from the other for work and labor, and any contract between them whereby one 
consideration, or they refuse enforcement because the agreement violates public policy. ${ }^{9}$

Second, even if the couple's agreement were an enforceable contract, as it might be if they were unmarried, ${ }^{10}$ the father's breach should only be excused if the couple's romantic relationship is an essential foundation of their agreement. Arguably, however, the parties' co-parenting relationship is the essential foundation of their agreement, and that relationship continues until their child reaches the age of majority. The parties' agreement never specified that the caregiving arrangement would end upon the termination of the parents' romantic relationship, even though the parties could have foreseen that possibility and addressed it. Their silence suggests that the romantic relationship was not an essential foundation of their agreement.

Third, the reasoning assumes that the father's obligation going forward has no connection to the caregiver's past acts, which may have been performed in reliance on their agreement. While her past acts may have been compensated already, either during the relationship or with a property award upon divorce, that is not necessarily so, especially if the family had few resources. Therefore, his obligation to pay her in the future may represent compensation for her past work. Consequently, even if changed circumstances were to release the father from any future obligation under their agreement, the changed circumstances would not affect his liability for obligations already incurred.

Fourth, the father's argument also assumes that the mother's caregiving going forward should be uncompensated, or that he can unilaterally determine the terms of the compensation. Even if the couple's original

shall claim or shall receive compensation from the other for services rendered, shall be void.").

9. See Marjorie Maguire Shultz, Contractual Ordering of Marriage: A New Model for State Policy, 70 Calif. L. Rev. 204, 230-31 (1982) ("Frequently by statute, and even more often by judicial precedent, spouses are prohibited from varying the legal terms of the marriage 'contract.' This prohibition is grounded either directly on the bar against varying the incidents of marriage, or indirectly on related theories of no consideration. Based on these policy analyses, courts have refused to enforce such agreements between spouses as: payment by one spouse to another for domestic, child care, or other services in the home; [and] . . alteration of statutory duties of support ...."); see also Twila L. Perry, The "Essentials of Marriage": Reconsidering the Duty of Support and Services, 15 Yale J.L. \& Feminism 1, 16-17 (2003) (noting that household labor is an essential of marriage and essentials cannot constitute consideration under contract law).

10. See Allen M. Parkman, The Contractual Alternative to Marriage, 32 N. Ky. L. Rev. 125, 148 (2005) ("Traditionally, agreements between unmarried couples that attempted to create rights and obligations similar to marriage were unenforceable. However, the recent trend has been to enforce contracts between cohabitating adults unless the agreement depends solely on unlawful meretricious relations. Courts have been willing to enforce contracts between unmarried couples based on common law principles of implied contract, equitable relief and constructive trust. Most of these cases deal with contracts for distributing assets when a relationship ends. Still, the decisions imply that the courts will enforce contracts specifying transfers during marriage and liquidated damages at dissolution."). 
agreement assumed the existence of a romantic relationship, and that agreement ceases to apply because of changed circumstances, there is no reason why the costs of future caregiving should be allocated solely to one of the parties by default.

\section{B. Freeloading, Really?}

Now some readers might think that it is too harsh to use the term "mooch" to characterize the fathers in the above scenarios. While they might benefit from the other parent's performance of a disproportionate amount of the caregiving labor, in many situations the caregiver appears to be volunteering her labor. It is wrong to label someone a mooch just because that person provides nothing in exchange for a gift, becauseafter all-it was a gift. And it is true that caregivers typically provide their services without expectation of compensation in the traditional sense.

But it also goes too far to say that all caregivers choose to give their services away for free. It is simply impossible to assess whether caregivers intend to gift their labor or whether they merely acquiesce in a regime that often fails to compensate them for the freeloading. In many situations, there is no remedy available, especially if the caregiver never married the child's other parent. In fact, it makes more sense to assume that caregivers are merely acquiescing, and not gifting their labor, because when caregivers do have a remedy-which tends to be at the time of divorce for married caregivers-those caregivers seek redress and point to their caregiving contributions as justifying the remedy. They do not act as if they were gifting their services, with no need for redress.

Certainly, many caregivers provide their caregiving without an express promise of compensation because they do not believe the other parent will treat them unfairly. They believe they are getting (or will get) something of value in return, including a share of the fruits of the other parent's market work. The caregiver's assumption about the fairness of the arrangement is most likely to be vindicated when the parents are, and stay, in a long-term loving relationship, typically marriage. But often relationships end and expectations become frustrated.

Still other caregivers probably care for their children without a promise of compensation because caregiving is a core component of who they are, and they are happy to do the work for free. For these caregivers, the other parent's (or child's) appreciation for their efforts may be sufficient remuneration. These caregivers' feelings are reinforced by strong cultural norms surrounding motherhood: society highly values the act of mothering and expects it to be uncompensated.

The martyrdom of these caregivers may be noble, but their selfless behavior is cheapened because they often forego something that they never had a right to anyway. Put another way, they forego nothing. Their martyrdom, coupled with the law's assumption that their caregiving is usually a gift, masks and fosters exploitation by the other parent. It is one 
thing for a caregiver to waive compensation voluntarily because she feels that she does not need or want it, but it is quite another thing to make her automatically a "volunteer" by denying her any legal claim to compensation.

Now some might point out that caregivers are not forced to do the caregiving so that their continued act of caregiving means that the situation must be Pareto-optimal. In many other situations in which there is an unfair allocation of work, the party who is suffering the disproportionate and unfair work burden can simply walk away. If the person does not walk away, then the situation is typically thought to be Pareto-optimal and the person is not "exploited," at least not sufficiently to justify government intervention. ${ }^{11}$

But, of course, caregiving is not like any other relationship of exchange. Children are not commodities. A caregiver's connection to her child and her desire to do what is best for her child mean she cannot simply walk away if the situation is unfair. Nor would we want that result. Nor does the law allow her to remedy the situation as others in the commercial world might. Caregivers cannot simply say, like Little Red Hen in the famous folk tale, "You did not do a fair share of the work to raise this child so you do not get to share in the joy of knowing him or her." The child is not like a loaf of bread to be parceled out.

Finally, some people may caregive without compensation because that arrangement is a quid pro quo for a sole custody award at the end of the parents' romantic relationship. The parents may never even discuss this bargain. The parent who wants sole custody may fear that even asking for caregiver compensation would trigger a counterproposal for shared caregiving, and so no request is made. In fact, the fear is understandable because some parents do seek custody solely for purposes of lowering their child-support obligation. ${ }^{12}$

The law facilitates a parent's ability to take advantage of the caregiver by ignoring the issue of caregiver compensation. To see how, compare the law's treatment of child support. Caregivers are under less pressure to forego child support in exchange for custody because the child's right to child support is unwaiveable, and the caregiver's income is irrelevant to a custody determination. If caregivers had an unwaiveable right to caregiver compensation, the law could similarly minimize the pressure to forego caregiver compensation in exchange for custody.

The unique dynamics of caregiving require that the law provide a remedy to rectify the unfairness that can sometimes attend this activity.

11. Cf. Amy L. Wax, Something for Nothing: Liberal Justice and Welfare Work Requirements, 52 EMORY L.J. 1, 18 (2003).

12. See, e.g., Susan Beth Jacobs, The Hidden Gender Bias Behind "The Best Interest of the Child" Standard in Custody Decisions, 13 GA. ST. U. L. Rev. 845, 846 (1997); Richard Neely, The Primary Caretaker Parent Rule: Child Custody and the Dynamics of Greed, 3 Yale L. \& Pol'y Rev. 168, 168 (1984); Jana B. Singer \& William L. Reynolds, A Dissent on Joint Custody, 47 MD. L. REv. 497, 503 (1988). 
Otherwise, freeloading and exploitation will continue. Lest there be any misunderstanding, the remedy proposed is a monetary one for the caregiver. While lawmakers might try instead to equalize the disproportionate caregiving between the parents, that response would be foolish: no remedy should ever require a parent to perform caregiving. Apart from the fact that the Thirteenth Amendment of the United States Constitution might preclude such a remedy (the Amendment prohibits involuntary servitude), ${ }^{13}$ such a remedy might endanger the child. A parent who is reluctant to caregive may become resentful if he or she has to caregive, and may take the resentment out on the child. Rather, here the proposed remedy is simply to award the caregiver sufficient financial compensation to rectify the unfairness.

\section{The Absence of a Remedy for Unmarried Caregivers}

Unmarried caregivers typically lack a remedy for disproportionate and unfair caregiving. Contrary to some popular misconceptions, child support does not provide unmarried caregivers an adequate remedy for their efforts, ${ }^{14}$ just as it does not negate the divorcing caregiver's need for

13. See Nathan B. Oman, Specific Performance and the Thirteenth Amendment, 93 Minn. L. Rev. 2020, 2091-92 (2009) (recognizing that, in some contexts, ordering specific performance may fall afoul of the Thirteenth Amendment).

14. Child support does not incorporate adequate compensation for caregiving efforts expended by the child's custodian. At best, child support may include funds for some, but not all, of the costs associated with third-party care. Child support regimes differ in their treatment of child care costs, but they usually employ one or more of the following methods to address them: incorporate the cost of child care into the base child support award; provide an add-on for child care expenses on top of the base award and allocate those expenses between the parents; consider child care expenses or time spent with the child to be a deviation factor; and, permit deductions from gross income for child care costs. See generally Laura Morgan, Child Support Guidelines: Interpretation and Application $\S 7.02$ (2013). "Regardless of the method used, all guidelines require that child care expenses be work-related and reasonable." Id. The income-shares model, which is the most popular method for calculating child support, incorporates the cost of child care into the base amount. The figures found in child support tables are based upon expenditure data from the Census Bureau's Consumer Expenditure Survey. That data includes child care and education expenses as a category. See Commonwealth of Mass., Massachusetts Child Support Guidelines Quadrennial Review: Final Report of the 2012 Task Force 20-21 (June 2013) [hereinafter QuAdrennial Review]. However, a child support award that relies solely on the base amount to cover child care costs likely undercompensates for those costs because the expenditure data comes from intact households only. The amount of caregiving that is "paid for" in intact families is presumably less than in divorced or non-marital/non-cohabiting families because an intact family may have a second parent available to watch the child when the first parent works. Consequently, a child support award may undercompensate for the real expense of child care in a divided family. Moreover, since any expenses incurred must be reasonable, courts may require the custodial parent to shoulder alone "unreasonable" expenses, which may be determined by the care's cost rather than the caregiver's need. For example, a state that allows incurred expenses to be deducted from gross income may depart downward from the guideline amount if the expense was disproportionate to the custodial parent's income. See, e.g., Office of the Chief Justice, 
a property division or alimony award. A caregiver's non-marital status does not result in any more child support than a divorcing caregiver receives.

The law tends to use marriage to differentiate between parents who will, and will not, have inter se obligations to the other parent beyond child support. The marriage line seems antiquated because so many children are now born outside of marriage. Over thirty years ago, New Zealand recognized the need for change and extended a "maintenance" remedy to any parent who provided day-to-day care for the child, even if the parents never lived together. ${ }^{15}$ It is time for the United States to update its laws.

\section{A. The Marriage Divide}

In the United States, unmarried caregivers (unlike divorcing caregivers) typically have no access to alimony and property awards to

Commonwealth of Mass., Child Support Guidelines 12 (Aug. 1, 2013) [hereinafter Child Support Guidelines]; Quadrennial Review, supra, at 71. If a child support regime requires child care expenditures before caregiving costs are shared (such as when a state deducts actual out-of-pocket child care costs from the gross incomes of both parents before computing their respective share of child support), then caregivers without such expenditures are disadvantaged. This would include caregivers who watch their children full-time instead of working in the market. This would also include caregivers who engage in market work, but cannot afford all of the necessary child care even with child support. Such custodial parents may have modified their activities (reduced their work hours, for example) or found no-cost solutions (such as relative care), but child support will not compensate the caregiver for these extra burdens. Very importantly, the child support awards do not compensate a custodial parent for time spent alone with the child during those periods for which child care is not needed, such as from dinnertime until the next morning when work begins. Additional responsibilities fall upon the caregiver when the parents live apart, and impose a range of costs on her (including opportunity costs regarding employment and leisure). Nor are caregivers' losses captured by an upward adjustment when the nonresident parent exercises less than the standard visitation assumed by the guidelines (in Massachusetts, standard visitation is 30 percent of the time with the children). See Quadrennial RevIEw, supra, at 70 . Such an adjustment can help, but the hidden costs that the guidelines themselves do not recognize are not captured by an upward adjustment either. Also, adjustments only work for caregivers if the nonresident parent exercises more than standard visitation. Finally, in some states, such as Massachusetts, advocates have argued that child support now precludes a custodian's ability to obtain alimony, thereby potentially entrenching losses that have never been adequately captured by child support. Massachusetts' new alimony law precludes a court from basing alimony on combined gross income that was used to calculate child support. Some have interpreted this provision to mean that alimony is unavailable for anyone with a combined gross income below $\$ 250,000$, the top income level for which the child support guidelines apply. See Quadrennial Review, supra, at 66-67. Others have extended the argument to those with incomes above $\$ 250,000$ also. See Ronald A. Witmer \& Mark Warner, Factors Utilized in Determining Alimony, in Massachusetts Divorce Law Practice \$ 9.6 (Mass. Continuing Legal Educ., Inc., Practice Manual MDLPMI MA-CLE 9-1, 2012).

15. See Patrick Parkinson, Family Law and the Indissolubility of Parenthood 264 (2011) (citing Family Proceedings Act 1980, section 79 (N.Z.)). 
remedy disproportionate and unfair caregiving. Most states lack domestic partner legislation, ${ }^{16}$ which might afford such remedies; but even when a domestic partnership option exists, unmarried couples with children often do not opt into the system. ${ }^{17}$ Similarly, common-law marriage, which changes an unmarried couple into a married one, would provide some cohabiting caregivers with access to property division and alimony. But few states still allow common-law marriage, and many caregivers do not qualify even where it exists. The few progressive states that automatically impose marital-like remedies on unmarried couples generally require that those couples had a marriage-like relationship, ${ }^{18}$ and not all caregivers qualify.

While many states allow unmarried parties to access the equitable remedies discussed in Marvin v. Marvin, ${ }^{19}$ the Marvin remedies are relatively unhelpful. Claimants often lack evidence of any of the following: an unjust enrichment (i.e., that the caregiving was not a gift), ${ }^{20}$ a monetary

16. Approximately seven states have domestic partnership or civil union statutes. See Jackie Gardina, Same-Sex Marriages in Bankruptcy: A Path Out of the Public Policy Quagmire, in Norton Annual Survey of Bankruptcy Law 411 (William L. Norton, Jr. ed., 2013); Civil Unions and Domestic Partnership Statutes, Nat'L Conf. OF ST. LEGIS., http://www.ncsl.org/research/human-services/civil-unions-and-domestic-partnership-statutes.aspx (last updated Dec. 20, 2013) (listing Nevada, Oregon, Washington, Hawaii, Maine, and Wisconsin as having either limited or broad domestic partnerships available). These regimes typically apply only to same-sex, not opposite-sex, couples. See Erez Aloni, Registering Relationships, 87 Tul. L. Rev. 573, 591 (2013). Some domestic partnership and civil union laws have been rendered redundant by same-sex marriage, which is now permitted in seventeen states and the District of Columbia. See Civil Unions and Domestic Partnership Statutes, supra.

17. One gets a rough sense of this reality by examining the number of couples with domestic partnerships in Nevada, a state that permits both same-sex and opposite-sex couples to register. According to the U.S. Census Bureau, approximately $7.3 \%$ of $1,000,000$ households in Nevada were unmarried partner households. See U.S. Census Bureau, American Fact Finder, 2012 American ComMUNITy SuRvey 1-Year Estimates, S1101. Although there are approximately 73,000 unmarried partner households, there are only 3,790 registered partnerships as of June 20, 2012. See Secretary of State Ross Miller, Biennial Report July 1, 2010-June 30, 2012, at 15 (Sept. 15, 2012).

18. See, e.g., Charlotte K. Goldberg, The Schemes of Adventuresses: The Abolition and Revival of Common-Law Marriage, 13 WM. \& MARY J. Women \& L. 483, 483 (2007) (discussing abolition of common-law marriage in California). Factors identified, although not exclusive, were "continuous cohabitation, duration of the relationship, purpose of the relationship, pooling of resources and services for joint projects, and the intent of the parties." In re Marriage of Pennington, 14 P.3d 764, 770 (Wash. 2000) (citing Connell v. Francisco, 898 P.2d 831, 834 (Wash. 1995)).

19. 557 P.2d 106, 109-10 (Cal. 1976); see also Steven K. Berenson, Should Cohabitation Matter in Family Law?, 13 J.L. \& FAM. STUd. 289, 296 (2011) (“A majority of states have followed at least some aspects of [Marvin].").

20. See Cynthia Lee Starnes, Alimony Theory, 45 FAm. L.Q. 271, 286-87 (2011); see also Morone v. Morone, 413 N.E.2d 1154, 1157 (N.Y. 1980) ("As a matter of human experience personal services will frequently be rendered by two people living together because they value each other's company or because they find it a convenient or rewarding thing to do."). Caregiving itself has been insufficient to support a quantum meruit claim to another's property. See, e.g., Rowson v. Denoyer, No. 11-P-1156, 2012 WL 2051151, at*1-2 (Mass. App. Ct. June 8, 2012) 
contribution to the property in dispute, ${ }^{21}$ a common intention to share ownership of the property, ${ }^{22}$ wrongdoing ${ }^{23}$ (often narrowly construed), ${ }^{24}$ or a "confidential relationship." 25 Reform efforts exist to expand the equitable remedies, but these efforts are not necessarily that beneficial for caregivers. For example, the Restatement (Third) of Restitution and Unjust Enrichment has a new remedy for unmarried couples. ${ }^{26}$ The commentary suggests that services qualifying for a remedy must not be part of the "reciprocal contributions normally exchanged between cohabitants whether married or not," 27 and one commentator stated that the Restatement's express language does not apply to the situation in which an unmarried cohabitant raises the couple's children while the other cohabitant

(allowing claim for quantum meruit for actual value of services performed remodeling house; domestic partnership alone did not give rise to claim for one-half of house titled in partner's name); Northrup v. Brigham, 826 N.E.2d 239, 243-44 (Mass. App. Ct. 2005) (allowing quantum meruit claim, but distinguishing case from one in which person provided services "ordinarily rendered by a wife in maintaining the home and in performing the usual household duties" (internal quotation marks omitted)); Mangsen v. Costa, No. 050313, 2009 WL 1082377, at *7 (Mass. Super. Ct. Mar. 4, 2009) (holding that quantum meruit claim requires underlying agreement about exchange). Another historic limit on unjust enrichment is that it is not available "to claimants who reasonably could have negotiated a consensual exchange." See Emily Sherwin, Love, Money, and Justice: Restitution Between Cohabitants, 77 U. Colo. L. Rev. 711, 712 (2006).

21. See, e.g., Maria v. Freitas, 832 P.2d 259, 264 (Haw. 1992) (finding plaintiff did not establish elements of constructive trust); Tarry v. Stewart, 649 N.E.2d 1, 4-6 (Ohio Ct. App. 1994) (finding property did not accumulate in constructive trust and lack of Ohio precedent allowing "cohabiting individuals to recover under a constructive trust theory for contributions to a relationship").

22. See 76 Aм. Jur. 2D Trusts $\$ 132$ (2013) (discussing resulting trusts "where the acts or expressions of the parties indicate an intent that a trust relation result from their transaction").

23. See, e.g., Jordan v. Mitchell, 705 So. 2d 453, 457-58 (Ala. Civ. App. 1997) (requiring proof of wrongdoing to support theory of unjust enrichment in context of imposing constructive trust); Maria, 832 P.2d at 264 (discussing equitable estoppel and finding no evidence of willful misleading).

24. See Northrup, 826 N.E.2d at 245 (finding record did not support constructive trust and unjust enrichment theories).

25. See Jordan, 705 So. 2d at 461 ("A confidential relationship exists when 'confidence is reposed by one party in another, and the trust or confidence is accepted under circumstances which show it was founded on intimate personal and business relations existing between the parties, which gave the one [advantage or] superiority over the other.'" (citation omitted)). A constructive trust can be imposed for abuse of a confidential relationship, but cohabitation alone-without marriage-is not per se evidence of such a relationship. See id. at 461-62. This can be true even if the parties have a child together. See, e.g., Tarry, 649 N.E.2d at 1, 6-7 (fourteen years of cohabitation and birth of child did not create confidential and fiduciary relationship between parties).

26. Restatement (Third) of Restitution and Unjust Enrichment $§ 28$ (2011). Section 28 allows a claim upon dissolution of a relationship when two people have "formerly lived together in a relationship resembling marriage," and one "made substantial, uncompensated contributions in the form of property or services" to a specific asset owned by the other. See id.

27. Id. at cmt. d. 
acquires all the assets. ${ }^{28}$ Moreover, the Restatement requires that the unmarried couple had a cohabiting relationship "resembling marriage" in order for one of its members to invoke the new provision's protections. ${ }^{29}$

While an unmarried caregiver might contract for a remedy, ${ }^{30}$ contracts between unmarried parents are "rare," 31 probably because unwed parties mistakenly believe that "some legal protections are available," 32 or they never think of entering a contract. Of course, contracts may also be rare because one party has nothing to gain by contracting. Moochers are unlikely to want to contract since the current law benefits them so completely. Implied contract claims are not a solution either because courts often want to see marital-like cohabitation, ${ }^{33}$ which may not exist, or courts find the terms of the agreement too amorphous to be enforceable. ${ }^{34}$

The bottom line is that many unmarried caregivers are out of luck when it comes to having a successful remedy for their disproportionate and unfair caregiving. ${ }^{35}$ Moreover, the patchwork of available remedies leaves most unmarried caregivers in legal limbo while they caregive. The caregiver rarely knows ahead of time whether or not a court adjudicating

28. See Sherwin, supra note 20, at 729-30. Professor Sherwin also recommends against courts adopting the Restatement's relaxed interpretation of unjust enrichment in the cohabitation context. See id. at 736-37. Her words of caution may stop courts from adopting the relevant Restatement's recommendations at all. The author, in fact, recommends that perhaps status-based claims would be a better way to afford relief. See id. at 720.

29. Restatement (Third) of Restitution and Unjust Enrichment, supra note $26, \S 28(1)$.

30. Elizabeth S. Scott, Marriage, Cohabitation and Collective Responsibility for Dependency, 2004 U. Chi. Legal F. 225, 255 (2004) ("Many courts have adopted this view [that ordinary contract principles apply to agreements between cohabiting parties] in recent years and have been ready to enforce these contracts.").

31. See Ira Mark Ellman \& Sanford L. Braver, Lay Intuitions About Family Obligations: The Case of Alimony, 13 TheORETICAL InQUiries L. 209, 234 n.32 (2012); see also Ira Mark Ellman, "Contract Thinking” Was Marvin's Fatal Flaw, 76 Notre Dame L. REv. 1365, 1367 (2001) ("[F] ew couples (married or unmarried) ... make express contracts at all ....").

32. Wilcox v. Trautz, 693 N.E.2d 141, 145 n.2 (Mass. 1998) (citing Twila L. Perry, Dissolution Planning in Family Law: A Critique of Current Analyses and a Look Toward the Future, 24 FAм. L.Q. 77, 77 n.1 (1990)).

33. See Goldberg, supra note 18, at 488; see, e.g., Goode v. Goode, 396 S.E.2d 430, 437-38 (W. Va. 1990) (holding court may order property division between unmarried cohabitants who held themselves out as husband and wife; order may be based on implied contract principles); Maria v. Freitas, 832 P.2d 259, 263-65 (Haw. 1992) (holding implied-in-fact contract did not exist to benefit cohabitant of nineteen years and co-parent, and refusing to award her separate property of partner or support payments even though couple was known as "husband and wife" to some members of public and claimant had homemaking role throughout relationship).

34. Cause of Action by Same-Sex or Heterosexual Unmarried Cohabitant to Enforce, 35 Causes of Action 2D $295 \$ 2$ (Dec. 2013).

35. See Berenson, supra note 19, at 297 (“[F]ew 'palimony' plaintiffs receive significant recoveries from the courts."). 
claims at the end of her romantic relationship will find present all of the prerequisites necessary to recovery. This uncertainty gives caregivers false hope and leaves them vulnerable if the relationship ends.

\section{B. The Prevalence and Difficulty of Unwed Caregiving}

The current legal framework is unfortunate because of the number of unmarried caregivers, the frequency of disproportionate caregiving, the effects of the disproportionality, and the externalities imposed on innocent parties.

First, non-marital births are no longer an anomaly. In 2009, almost $1,700,000$ children were born to unmarried parents. ${ }^{36}$ In percentage terms, approximately forty-one percent of the births each year are to unmarried women, up from about five percent in $1960 .{ }^{37}$

Second, unmarried caregivers often do a disproportionate share of the caregiving labor. Whenever the parents live apart, the caregiving work will fall largely on the parent with physical custody of the child. In one study, approximately fifty percent of the unwed mothers did not cohabit with the father at the time of birth, and nine percent of the mothers had little or no contact at all with the fathers. ${ }^{38}$ Unwed mothers overwhelmingly have physical custody of their children. ${ }^{39}$ Over time, unmarried mothers' relationships with their children's fathers often deteriorate, and the fathers' involvement in their children's lives falls off. In the study mentioned above, by the child's fifth birthday, sixty-three percent of all fathers were living away from the mother and child, ${ }^{40}$ and less than half of

36. See Brady E. Hamilton et al., Births: Preliminary Data for 2009, CDC NAT'L Vital Stat. Rep. 1, 4 (2010) (reporting total number of births to unmarried women fell from $1,726,566$ in 2008 to $1,693,850$ in 2009).

37. See id.; see also Pew Research Ctr., As Marriage and Parenthood Drift Apart, Public Is Concerned About Social Impact 15 (2007) (discussing rise of non-marital childbearing in United States from 1960 to 2005). This rise in the percentage of births that are non-marital is mainly attributable to the fact that fewer married women are having children, but the actual number of non-marital births is nonetheless notable in and of itself. See Andrew J. Cherlin, American Marriage in the Early Twenty-First Century, Future Child.: Marriage \& Child Wellbeing, Fall 2005, at 33, 35, available at http://futureofchildren.org/futureofchildren/ publications/journals/article/index.xml?journalid=37\&articleid=105.

38. See Sara Mclanahan, Irwin Garkinkel \& Ronald B. Mincy, Fragile Families, Welfare Reform, and Marriage 2 (Brookings Inst. Policy Brief No. 10, 2001), available at http://www.brookings.edu/research/papers/2001/12/childrenfamilies-mclanahan.

39. See Glendessa M. Insabella et al., Individual and Coparenting Differences Between Divorcing and Unmarried Fathers, 41 Fам. Cт. Rev. 290, 298 (2003) (finding at initiation of court proceedings, 86 percent of unmarried mothers had primary physical custody, 8.3 percent of fathers had primary physical custody, and 5.6 percent had joint physical custody).

40. See Marcia J. Carlson, Sara S. McLanahan \& Jeanne Brooks-Gunn, Coparenting and Nonresident Fathers' Involvement with Young Children After a Nonmarital Birth, 45 Demography 461, 461, 472 (2008) (using data from The Fragile Families and Child Wellbeing Study). 
the children with nonresident fathers had ongoing contact with their fathers. Thirty-seven percent of the children with nonresident fathers had no contact with their fathers in the previous one to two years. ${ }^{41}$ In another study, unwed fathers who paid child support averaged only sixty-one days of contact per year with their children. ${ }^{42}$ Fathers with regular visitation commonly exercise their visitation on evenings and weekends-an arrangement that minimizes the chance that caregiving will interfere with his work obligations.

These patterns are evident among teenage mothers too. Approximately 400,000 children each year are born to teenagers. ${ }^{43}$ Most teen fathers are not married to the mothers of their children, nor do they live with them. ${ }^{44}$ Many of these girls find themselves doing a disproportionate amount of the caregiving. Some scholars report that "teenage mothers are likely to receive little in the form of direct caregiving from the baby's father." 45 While other family members often help these girls, ${ }^{46}$ a girl's parenting obligations still reduce her leisure, ${ }^{47}$ impact her own education, ${ }^{48}$ exact psychological costs (such as increased worries and anxieties), and require considerable physical labor. ${ }^{49}$ While teenagers are not the largest group of unmarried parents, the imbalance in parenting responsibility among this population is notable because the youngest mothers are likely to have the greatest vulnerabilities among unmarried caregivers generally.

Third, unmarried caregivers of all ages experience hardship from their caregiving. Being a "single parent" is difficult, especially when that parent also works or attends school. One divorced mother described

41. See id. at 473 .

42. See Robert I. Lerman, Capabilities and Contributions of Unwed Fathers, Future Child.: Fragile Families, Fall 2010, at 73-74, available at http://www.future ofchildren.org/futureofchildren/publications/journals/article/index.xml?jour nalid $=73 \&$ carticleid $=531$.

43. See CDC Vital Signs, Preventing Teen Pregnancy in the U.S. 1 (2011), available at http://www.cdc.gov/vitalsigns/pdf/2011-04-vitalsigns.pdf.

44. Resilience Advocacy Project, Who Cares About Teen Dads? How Family Court Reform Can Help Break a Cycle of Poverty 2 (Resilience Advoc. Proj. Policy Brief No. 1, 2012), available at http://resiliencelaw.org/wordpress2011/wpcontent/uploads/2012/06/Teen-Father-White-Paper-FINAL-VERSION.pdf.

45. Loretta Pinkard Prater, Never Married/Biological Teen Mother Headed Household, in Single Parent Families: Diversity, Myths and Realities 305, 314 (Shirley M. H. Hanson et al. eds., 1995); see also Celeste A. Lemay et al., A Qualitative Study of the Meaning of Fatherhood Among Young Urban Fathers, 27 Pub. Healtu Nursing 221, 222 (2010).

46. See Rachel Connelly \& Jean Kimmel, The Time Use of Mothers in the United States at the Beginning of the 21st Century 131 (2010).

47. See Margaret Mietus Sanik \& Teresa Mauldin, Single Versus Two Parent Families: A Comparison of Mothers' Time, 35 FAM. ReL. 53, 55-56 (1986).

48. See Prater, supra note 45, at 311-12.

49. See James T. Fawcett, The Value of Children and the Transition to Parenthood, in Transitions to Parenthood 16 (Rob Palkovitz \& Marvin B. Sussman eds., 1988) (identifying categories of costs of having children, including physical costs). 
caregiving without a partner: "'Being a single mom is exhausting. When you parent alone, you are the breadwinner, the bread maker, the police, the comforter, taxi driver. Not to mention all the things that go along with owning a home and an automobile." 50 A contributor to SingleMom .com revealed that being a single mother is hard because "it's unending, there isn't ever a break, there isn't a backup plan. No matter what, everything hinges on you." ${ }^{1}$ Even women who parent alone by choice (typically an economically privileged bunch) speak about the tremendous work it entails. Lori Gottlieb's article in The Atlantic chided "single-mom books" for not mentioning the following:

[O]nce you have a baby alone, not only do you age about 10 years in the first 10 months, but if you don't have time to shower, eat, urinate in a timely manner, or even leave the house except for work, where you spend every waking moment that your child is at day care, there's very little chance a man-much less The One-is going to knock on your door and join that party. ${ }^{52}$

Professor Anne Alstott's words seem particularly apt for caregivers who do not cohabit with the other parent: "[It] is not that parents feel burdened, but . . . they are burdened."53

Caregiving often has adverse economic consequences for the caregivers. Caregiving can come at the expense of market work, and market work brings income, retirement benefits, and Social Security credit. ${ }^{54}$ Even a caregiver who combines market and non-market work with a flexible or part-time job faces economic repercussions from those accommodations. ${ }^{55}$ Caregivers who work fulltime suffer financially too. Researchers have repeatedly noted a wage gap for women with children. ${ }^{56}$ Estimates vary, but several researchers have mentioned a wage penalty of approxi-

50. Erin Andersen, Going It Alone: Single Moms Share Their Stories, Lincoln J. STAR (May 12, 2012), http://journalstar.com/lifestyles/family/going-it-alone-single-moms-share-their-stroeis/article_d705611c-0879-5b55-a402-fb7efb7d26c4.html.

51. This is a Marathon, SingleMom.com, http://www.singlemom.com/this-isa-marathon/\#comments (last visited Oct. 28, 2013).

52. Lori Gottlieb, Marry Him!, The Atlantic, March 2008, available at http:// www.theatlantic.com/magazine/archive/2008/03/marry-him/306651/.

53. Anne L. Alstott, No Exit: What Parents Owe Their Children and What Society Owes Parents 56 (2004).

54. See Ann Crittenden, The Price of Motherhood: Why the Most Important Job in the World Is Still the Least Valued 77-78 (2001).

55. See id. at 89; see also Cynthia Lee Starnes, Mothers, Myths, and the Law of Divorce: One More Feminist Case for Partnership, 13 Wм. \& MARY J. Women \& L. 203, 209, 215-17 (2006) (describing costs of motherhood).

56. See, e.g., Deborah J. Anderson et al., The Motherhood Wage Penalty Revisited: Experience, Heterogeneity, Work Effort, and Work-Schedule Flexibility, 56 Indus. \& LaB. Rel. Rev. 273, 291 (2003) [hereinafter Anderson et al., Motherhood Wage Penalty Revisited]; Deborah J. Anderson et al., The Motherhood Wage Penalty: Which Mothers Pay It and Why, 92 Am. Econ. Rev. 354, 354 (2002) [hereinafter Anderson et al., Motherhood Wage Penalty]; Michelle J. Budig \& Paula England, The Wage Penalty for Motherhood, 66 Ам. Soc. Rev. 204, 204, 219 (2001); see also Alstotт, supra note 53, 
mately four to five percent if a woman has one child. ${ }^{57}$ The economic effects of caregiving persist over time and leave an indelible mark of "caregiver" on these workers' paychecks. The American Law Institute reported: "Economic studies demonstrate that responsibility for the care of children ordinarily has a significant continuing impact on parental earning capacity. This effect is not limited to parents who withdraw from fulltime employment. It is also observed among primary caretakers who continue full-time market labor." 58

In contrast, the other parent-the one who does less than half of the caregiving-experiences real economic benefits from being less encumbered by caregiving responsibilities. A person can usually earn much more money by being the perfect employee, that is, someone with few caregiving obligations to divert him or her away from employment responsibilities. Studies show that workers without children tend to make more money, even after controlling for variables like education and years of employment. ${ }^{59}$ Similarly, fathers whose partners are stay-at-home moms earn on average thirty percent more than fathers in families with two-career parents. ${ }^{60}$ Having less responsibility for caregiving means that a market worker has more time for work. Even an unemployed parent benefits if the other parent does most of the caregiving. The unemployed parent has more time to look for a job, go to school, or engage in leisure.

Fourth, and finally, the absence of a remedy for unmarried caregivers produces externalities. While the economic repercussions of caregiving are often imposed on the caregiver, the costs are sometimes also imposed on those with no biological connection to the child. For example, taxpayers bear some of the costs of caregiving when the caregiver receives public assistance, although this externality might be unavoidable if the father is poor too. Additionally, the costs often are shifted to the caregiver's subsequent partner. Unmarried parents, like divorced parents, frequently re-

at 172; Rebecca Glauber, Marriage and the Motherhood Wage Penalty Among African Americans, Hispanics, and Whites, 69 J. Marriage \& FAm. 951, 958 (2007).

57. See Budig \& England, supra note 56, at 220 (finding "remaining motherhood penalty of about 4 percent per child"); Glauber, supra note 56, at 954-55 (discussing how findings of current study are consistent with Budig and England study in which "women with one child pay a $3 \%$ wage penalty").

58. Principles of the Law of Family Dissolution, Analysis \& RecommendaTIONS $\$ 5.05 \mathrm{cmt}$. d (2002) [hereinafter Principles]; see also id. reporter's notes, cmt d; Cynthia Lee Starnes, Mothers as Suckers: Pity, Partnership, and Divorce Discourse, 90 Iowa L. Rev. 1513, 1523-24 (2005).

59. See, e.g., Jane Waldfogel, The Effect of Children on Women's Wages, 62 Ам. Soc. Rev. 209, 216 (1997); Jane Waldfogel, Understanding the "Family Gap" in Pay for Women with Children, 12 J. Econ. Persp. 137, 143 (1998); see also Anderson et al., Motherhood Wage Penalty Revisited, supra note 56, at 282.

60. Tamar Lewin, Men Whose Wives Work Earn Less, Studies Show, N.Y. Times (Oct. 12, 1994), http://www.nytimes.com/1994/10/12/us/men-whose-wives-workearn-less-studies-show.html?pagewanted=all\&src=pm. 
couple with others after breaking up, ${ }^{61}$ although a child can reduce a caregiver's likelihood of re-partnering. ${ }^{62}$ If the caregiver's new relationship is a marital relationship, then her new spouse will have a legal obligation of support. That support obligation will include the obligation to pay alimony at their relationship's end, even if her need for alimony arises from caregiving for a non-joint child. If the unmarried caregiver enters a cohabiting relationship, rather than marriage, ${ }^{63}$ then her new partner frequently contributes to her support, despite the absence of a legal obligation to do so. ${ }^{64}$ At the same time, the non-custodial parent will typically

61. Bendheim-Thoman Ctr. for Research on Child Wellbeing \& Soc. Indicators Survey Ctr., Fragile Families Research Brief No. 39, Parents' Relationship Status Five Years After a Non-Marital Birth 2 (2007), available at http://www.fragilefamilies.princeton.edu/briefs/ResearchBrief39.pdf.

62. Mothers remarry less than childless women. See Sharon H. Bzostek et al., Mother's Repartnering After a Nonmarital Birth, 90 SOC. Forces 817, 820 (2012) (citing studies); see also Leslie Buckle et al., Marriage as a Reproductive Contract: Patterns of Marriage, Divorce, and Remarriage, 17 Eтhology \& Sociobiology 363, 371 (1996). Women with children under six years old have the lowest remarriage rate of all. See Megan M. Sweeney, Remarriage of Women $\mathcal{E}$ Men After Divorce, 18 J. Fam. Issues 479, 493 (1997) (finding thirty-seven percent reduction in chance of marriage compared to women with no children). Perhaps not surprisingly, a divorced woman's chance of cohabitating with a new partner is also negatively affected if she has a child at home. See Paul M. de Graaf \& Matthijs Kalmijn, Alternative Routes in the Remarriage Market: Competing-Risk Analyses of Union Formation After Divorce, 81 Soc. Forces 1459, 1462-66, 1489 (2003); see also Bzostek et al., supra, at 820. In contrast, fathers' remarriage prospects decline generally only when their children are teenagers or older, probably because fathers are not typically the primary custodian for their young children; therefore, their children are less of an impediment to new relationships. See Sweeney, supra, at 496-97. But see Frances Goldscheider et al., Navigating the "New" Marriage Market: How Attitudes Toward Partner Characteristics Shape Union Formation, 30 J. Fam. Issues 719, 722 (2009) (citing studies that showed children have no effect, or even positive effect, on men's union formation, although noting studies rarely distinguish residential status of parent).

63. A woman with a nonmarital birth is much more likely to cohabit with than marry her new partner. See Zhenchao Qian et al., Out-of-Wedlock Childbearing, Marital Prospects and Mate Selection, 84 Soc. Forces 473, 481 (2005).

64. See Cynthia Grant Bowman, Social Science and Legal Policy: The Case of Heterosexual Cohabitation, 9 J.L. \& FAм. Stud. 1, 23-24 (2007) ("A majority of [ ] cohabitants . . . maintain joint finances."). While "virtually all" cohabitants with a common child pool their income, similar statistics are not available for situations in which the cohabitants have a child in the home, but that child is the child of only one of the parties. See id. at 35. Chances are, however, that the sharing behavior is higher than for cohabitants without a child in the home, but lower than for cohabitants with a common child in the home. While the number of cohabitants who support a partner who caregives for a non-joint child is unknown, it appears unexceptional judging from all of the questions on the internet about the tax consequences of doing so. See, e.g., Bez513, How/Can I Claim Deductions for My Girlfriend and Her Daughter That Lived with Me All Year?, TurboTax AnswerXchange (2011), https://ttlc.intuit.com/questions/1474490-how-can-i-claim-deductions-formy-girlfriend-and-her-daughter-that-have-lived-with-me-all-year; Can I Claim My Girlfriend and Her 2 Sons as Dependents on My Taxes?, YaHOo! Answers (2009), http:/ /answers.yahoo.com/question/index?qid=20100108052926AAVJpGh; If My Girlfriend and Her Children Live with Me and Their Father Isn't Around, Can I Claim My 
pay nothing for the economic effects of the caregiving. The biological father's obligation to the caregiver differs significantly from his support obligation to his child, where biology determines which adult has financial obligations to support the child. ${ }^{65}$ States are very reluctant in the child support context to impose the cost of raising a child on someone who is not the biological parent, such as a stepparent. ${ }^{66}$

\section{An Unjust Line}

While marriage imposes on spouses the legal obligation to support each other during the ongoing relationship and, at times, when it is over, unmarried caregivers cannot rely on marriage to the other parent as the solution. First, many people do not want to marry, often for good reasons. Some consider the institution unjust and blame it for perpetuating rigid gender roles. ${ }^{67}$ Some do not want to marry because the other party is abusive or a risk to the family. ${ }^{68}$ Yet others refuse to marry until they and their partners are economically secure, so that their marriage will have a greater chance of surviving. ${ }^{69}$ Second, marriage is not an option for everyone because the law sometimes makes it unavailable, such as for many gay and lesbian parents, or for parents who have children with already-married individuals. Third, and particularly important, it takes two willing parties to marry. There are cases where the caregiver wants to marry, but the other parent does not agree, thereby depriving the caregiver of the law's divorce remedies for disproportionate and unfair caregiving. In sum, marriage is not a solution for everyone.

Girlfriend and Her Children as Dependents?, H\&R Block, Your Tax Questions ANSWERED, http://www.hrblock.com/tax-answers/services/jsp/article.jsp?article_id= 66387 (last visited Oct. 30, 2013).

65. See Leslie Joan Harris, The Basis for Legal Parentage and the Clash Between Custody and Child Support, 42 InD. L. Rev. 611, 612 (2009).

66. 59 Aм. Jur. 2d Parent and Child $§ 12$ (2014); Carol Rogerson, The Child Support Obligation of Step-parents, 18 Canadian J. Fam. L. 9, 41 (2001).

67. See Joanna M. Reed, Not Crossing the "Extra Line": How Cohabitors with Children View Their Unions, 68 J. Marriage \& Fam. 1117, 1124 (2006) (giving examples of individuals dissuaded from marriage because of gender roles associated with it); $c f$. Brad Pitt, My List, EsQuire Mag., Oct. 2006, at 166 (explaining his reluctance to marry until same-sex marriage is legal).

68. Many unmarried couples with children break up because of domestic violence, cheating, crime, imprisonment, and drug and alcohol use. See Kathryn Edin \& Joanna M. Reed, Why Don't They Just Get Married? Barriers to Marriage Among the Disadvantaged, Future Child.: Postsecondary Educ. U.S., Fall 2005, at 123, available at http://futureofchildren.org/futureofchildren/publications/journals/article $/$ index.xml?journalid=37\&articleid=109 (noting, for example, that over half of women in one study cited "a chronic pattern of domestic violence," and 40 percent noted "flagrant infidelities").

69. See Kathryn Edin \& Maria J. Kefalas, Promises I Can Keep: Why Poor Women Put Motherhood Before Marriage 129-30 (2005); Edin \& Reed, supra note 68 , at $122-23$. 


\section{The Inadequacy of Existing Remedies for Married Caregivers}

Channeling people into marriage also does not solve the freeloading problem because the law permits freeloading among divorced parents. Married couples frequently divorce. ${ }^{70}$ The law governing divorce is itself insufficiently attentive to justice for caregivers. In fact, couples typically divorce when their children are very young and there remains considerable caregiving to be done. ${ }^{71}$ But, courts rarely focus on this fact to justify a compensatory remedy for future caregiving work.

\section{A. The Segmentation of Caregiving}

The inadequacy of divorce law is best seen by breaking caregiving into three time periods: caregiving that occurs before the marriage; caregiving that occurs during the marriage; and caregiving that occurs after the end of the marriage. Caregivers are likely to receive a remedy for the caregiving that occurs during the marriage, but not for caregiving during the other two time periods.

Most states provide divorcing caregivers an equitable share of the couple's marital property, ${ }^{72}$ and thereby reward disproportionate marital caregiving when it would be unfair not to do so. The 1973 Uniform Marriage and Divorce Act (UMDA) specifically mentions as a relevant factor to the division of property the "contribution or dissipation of each party in the acquisition, preservation, depreciation, or appreciation in value of the respective estates, and the contribution of a spouse as a homemaker or to the family unit."73 The theory behind the UMDA's approach is that marriage is a partnership, and both parties are entitled to share in the fruits of that partnership, whether the fruits are well-adjusted children or the acquisition of material wealth. The UMDA also permits the court to consider the caregiver's need, ${ }^{74}$ which can be influenced by marital caregiving. A few

70. See Nat'l Marriage Project \& Inst. for Am. Values, The State of Our Unions: When Marriage Disappears: The New Middle America 71 (W. Bradford Wilcox ed., 2010) ("The average couple marrying for the first time now has a lifetime probability of divorce or separation somewhere between 40 and 50 percent.").

71. "Twenty-five percent of married couples in the United States divorce in the five years following a baby's birth." Hara Estroff Marano, Parenting: Here Comes Trouble, Psychol. Today, Nov.-Dec. 2004, at 14. The average time until divorce for first marriages is eight years. See Press Release, U.S. Census Bureau, Most People Make Only One Trip down the Aisle, but First Marriages Shorter (Sept. 19, 2007), http:/ / www.prnewswire.com/news-releases/most-people-make-only-one-trip-down-theaisle-but-first-marriages-shorter-census-bureau-reports-58151357.html. 2013)

72. See Barth H. Goldberg, Valuation of Divorce Assets \$ 10:4 (rev. ed.

73. Unif. Marriage \& Divorce Act $\S 307$ [Alternative A] (amended 1973), 9A U.L.A. 288 (1998) (emphasis added).

74. For example, the Uniform Marriage and Divorce Act (UMDA) sets forth a number of factors to consider. See Unif. Marriage \& Divorce Act § 307 notes of decisions 151-270 (amended 1973), 9A U.L.A. 347-98 (1998). Only Alternative A expressly sets forth the needs of the parties as a relevant factor to consider. 
states also use a property award to address a caregiver's premarital caregiving, ${ }^{75}$ so long as the caregiver later married the other parent.

Divorcing caregivers can also receive alimony, although the reasons for which caregivers receive it differ from place to place. Alimony is sometimes used to compensate the caregiver for her marital caregiving activity. She might be entitled to part of the other parent's enhanced earning capacity when her caregiving contributed to the market worker's enhanced earning capacity. ${ }^{76}$ Alternatively, alimony is sometimes used to remedy the caregiver's loss in earning capacity caused by marital caregiving, ${ }^{77}$ especially when the divorcing couple lacks adequate property to compensate the caregiver for her economic sacrifices, which is often the case. ${ }^{78}$ This approach is recommended in the American Law Institute's Principles of the Law of Family Dissolution: Analysis and Recommendations (ALI Principles), as discussed below.

Perhaps most commonly, however, alimony is used to address the divorcing caregiver's "need" that arose from marital caregiving, so long as her husband has the ability to pay. Depending upon the jurisdiction and era, ${ }^{79}$ the alimony award might reflect what the recipient needs after divorce to stay off welfare, ${ }^{80}$ perhaps what she needs to survive at the same standard of living as during the marriage, ${ }^{81}$ or perhaps only what she needs to rehabilitate herself so that she can reenter the work force and support herself. ${ }^{82}$

Parents who will caregive after divorce might also receive alimony for their need. Courts still tend to allocate physical custody primarily to one

75. See, e.g., Alimony Reform Act of 2011, Mass. Gen. Laws ch. 208, § 48 (2012) (defining "length of the marriage"); Charles P. Kindregan, Jr., Reforming Alimony: Massachusetts Reconsiders Postdivorce Spousal Support, 46 SuffolK U. L. REv. 13, 28, 29 n.84 (2013).

76. Most states do not consider enhanced earning capacity to be property since the income is only realized after the marriage ends; therefore, courts sometimes capture it instead through an alimony award.

77. See Starnes, supra note 20, at 273.

78. See Ira Mark Ellman, The Maturing Law of Divorce Finances: Toward Rules and Guidelines, 33 FAM. L.Q. 801, 809 (1999).

79. The UMDA allows an award for maintenance and includes a list of factors relevant to the determination of a just award. See Unif. Marriage \& Divorce Act $\S 308$ (b) (amended 1973), 9A U.L.A. 446 (1998). Need seems to be the dominant consideration. In fact, a prerequisite to an award is that the recipient lacks sufficient property to provide for his or her reasonable needs and cannot work to meet those needs, or is a custodian of a child and should not be expected to seek employment outside the home. See id. § 308(a). The Reporters for the American Law Institute note that while need is the dominant justification for spousal support, need is a weak explanatory rationale for why the ex-spouse is obligated to pay the support as opposed to society. See Principles $\S 4.09 \mathrm{cmt}$. d. (1998).

80. See Unif. Marriage \& Divorce Act $\$ 308$ (amended 1973), 9A U.L.A. 446

81. See id. §308(b) (3).

82. See Katharine K. Baker, Contracting for Security: Paying Married Women What They've Earned, 55 U. CHI. L. Rev. 1193, 1200 (1988). 
party at divorce, typically the mother, who then does most of the caregiving. ${ }^{83}$ The caregiving may reduce that parent's ability to support herself. The UMDA explicitly states that need plus ongoing caregiving (that might interfere with paid labor) can justify a maintenance award. ${ }^{84}$ However, courts are uncharitable in permitting caregiving after divorce to substitute for paid labor, and they rarely award alimony for this purpose. ${ }^{85}$ Any such award is generally limited to a short duration. ${ }^{86}$ In fact, one study found that financial awards are often inversely related to the amount of caregiving to be performed after the relationship ends: the more custody a woman receives (e.g., sole custody), the less likely she is to receive alimony. ${ }^{87}$

Most importantly, apart from a property award for past caregiving and an alimony award predicated on need, divorcing caregivers are unlikely to receive anything else. Caregivers are usually not compensated for caregiving that occurs during the post-divorce period. Courts rarely recognize that regardless of need, caregivers deserve a remedy because they give something to the other parent that deserves compensation. Former Ohio State law professor Joan Krauskopf explained a long time ago that an award for post-divorce caregiving could be accommodated under existing alimony theory because alimony is available to "fairly share gains and losses in personal earning capacity" 88 in order to prevent unjust enrichment. ${ }^{89}$ However, courts then, and still today, rarely make the parties share the economic burden of (or gains from) caregiving after divorce. ${ }^{90}$

83. See Insabella et al., supra note 39, at 298 (reporting at initiation of court proceedings, 60 percent of mothers had primary physical custody, 8 percent of fathers had primary physical custody, and 32 percent had joint physical custody). After the court proceedings conclude, it appears that mothers have primary custody more often. See Nancy E. Dowd, Stigmatizing Single Parents, 18 Harv. Women's L.J. 19, 61 n.264 (1995) (maternal custody exists in approximately 90 percent of cases, and most cases are decided by settlement instead of litigation); see also Maria Cancian \& Daniel R. Meyer, Who Gets Custody?, 35 Demography 147, 149-50 (1998) (reporting that between 1992 and 1994, 73.7 percent of mothers were awarded primary physical custody in twenty-one Wisconsin counties).

84. See Unif. Marriage \& Divorce Act $\$ 308(a)$ (amended 1973), 9A U.L.A. 446 (1998).

85. Professor Ann Estin reports that few courts award alimony to allow one parent to care for the couple's child. See Ann Laquer Estin, Maintenance, Alimony, and the Rehabilitation of Family Care, 71 N.C. L. REv. 721, 727, 731 (1993).

86. See id. at 738 . 50 .

87. Susan Elgin, Alimony Guidelines: Is It Time?, MD. B.J., May-June 2005, at 46,

88. Joan M. Krauskopf, Theories of Property Division/Spousal Support: Searching for Solutions to the Mystery, 23 FAM. L.Q. 253, 266 (1989). There are other purposes, including to compensate for loss of marriage prospects and for physical or mental injury. See id. at 266-67.

89. See id. at 260.

90. See id. at 265. As a general matter, spousal support is a relatively rare remedy. Only six percent of the total cases examined in 2003 at all income levels had alimony awards. See Nancy D. Polikoff, Beyond (Straight and Gay) MarRiage: Valuing All Families Under the Law 128 (2008). Ann Estin noted twenty years ago, "caregiving . . . is almost entirely irrelevant when courts resolve the fi- 
The reason courts have been reluctant to provide caregivers a remedy for their post-divorce caregiving relates to the "clean break" philosophy that has infiltrated divorce law. That philosophy encourages courts to disentangle the couple economically at divorce, if possible. The idea emerged from the UMDA, promulgated approximately forty-five years ago, ${ }^{91}$ and remains strong today. In 1996, Professor Milton Regan called it "the predominant aim" of divorce law's treatment of financial obligations. ${ }^{92}$ In 2012, Professor Starnes reported that the laws at divorce still "remain wed to the clean-break myth that divorce can end or minimize all economic ties between spouses with children."93 The doctrine has remained steadfast even though it is now antiquated, in light of the way divorced parents today are entangled during their child's minority, including from child support and custody.

nancial incidents of divorce, even where it has produced substantial long-term economic effects for family members." Estin, supra note 85, at 721. As she points out, this is especially true for younger families "subject to new and different norms of family life in which self-sufficiency and autonomy are of primary importance." Id. at 722. Scholar Joan Williams noted that poor women "have not traditionally been awarded alimony." See Joan Williams, Is Coverture Dead? Beyond a New Theory of Alimony, 82 Geo. L.J. 2227, 2231 (1994). Permanent alimony appears to have become increasingly disfavored over time. Lenore Weitzman reported that approximately fourteen percent of divorced women received alimony in 1978. LENORE WeITZman, The Divorce Revolution 168 (1985). In 2009, approximately thirty years later, the number of people receiving permanent alimony appears to be more like two percent. Compare U.S. Census Bureau, Marital Status of People 15 Years and over, by Age, Sex, Personal Earnings, Race, and Hispanic Origin, tbl.A1 (2009), http://www .census.gov/population/www/socdemo/hh-fam/cps2009.html (reporting $13,308,000$ as number of divorced women age fifteen years and older), and U.S. Census Bureau, Current Population Survey, Annual Social and Economic Supplement, Source of Income in 2009-People 15 Years and over, All Races (2009), http:/ /www.census.gov/hhes/www/cpstables/032010/perinc/new08_181.htm (reporting 320,000 women age fifteen years and older receiving alimony); see also Heather Ruth Wishik, Economics of Divorce: An Exploratory Study, 20 FAM. L.Q. 79, 81, 85 (1986) (finding "less than $7 \%$ of spouses receive spousal maintenance awards, and less than $2 \%$ receive awards of unlimited duration" in study of Vermont divorce cases from October 1982 to February 1983).

91. See Naomi R. Cahn, The Moral Complexities of Family Law, 50 Stan. L. Rev. 225, 261 n.162 (1997) (citing Unif. Marriage \& Divorce Act (amended 1973), 9A U.L.A. 101-506 (1998)).

92. Milton C. Regan, Jr., Postmodern Family Law: Toward a New Model of Status, in Promises to Keep: Decline and Renewal of Marriage in America 157, 174 (David Popenoe, Jean Bethke Elshtain \& David Blankenhorn eds., 1996); see also Alicia Brokars Kelly, The Marital Partnership Pretense and Career Assets: The Ascendancy of Self over the Marital Community, 81 B.U. L. Rev. 59, 75 (2001) (citing Milton C. Regan, Jr., Spouses and Strangers: Divorce Obligations and Property Rhetoric, 82 GEO. L.J. 2303, 2314 (1994)); Cynthia Starnes, Divorce and the Displaced Homemaker: A Discourse on Playing with Dolls, Partnership Buyouts and Dissociation Under No-Fault, 60 U. Chi. L. Rev. 67, 85, 108 (1993) (noting that partnership model views divorce as termination of parties' mutual responsibilities).

93. Cynthia Lee Starnes, Lovers, Parents, and Partners: Disentangling Spousal and Co-parenting Commitments, 54 ArIz. L. Rev. 197, 199 (2012). 


\section{B. Uncaring Reforms}

Recent reforms of alimony law have disadvantaged caregivers and have made it more unlikely that they will receive adequate compensation at divorce for their marital or post-marital caregiving. For example, Massachusetts's Alimony Reform Act of $2011^{94}$ hamstrings judges in their efforts to afford caregivers' justice, although it is touted as "the latest and the most comprehensive" of efforts to reform alimony in the United States, ${ }^{95}$ and a "model for consideration elsewhere." 96 The Act is problematic for caregivers in at least six ways.

First, caregiving is not expressly relevant to an alimony award. Nowhere are courts told to remedy a caregiver's disproportionate and unfair caregiving, performed either during the marriage or after divorce. The fact that someone is, has been, or will be the caregiver for the parties' child is not listed as a relevant factor to a court's determination of the type, amount, or duration of alimony. ${ }^{97}$ While caregiving might be relevant indirectly to some of the listed factors, ${ }^{98}$ Massachusetts's new statute specifically eliminated as a relevant factor the "contribution of each of the parties as a homemaker to the family unit,"99 although it was included in the prior law. Nor is caregiving mentioned in the nonexclusive list of factors that could support deviation from the guidelines, either for an initial award or for a modified award. ${ }^{100}$

Second, the statute insufficiently recognizes a compensatory rationale for marital caregiving. The statute has four categories of alimony: general term, rehabilitative, reimbursement, and transitional. The statute does not mention as one of alimony's purposes the compensation of a caregiver for her lost earning capacity attributable to her marital caregiving. ${ }^{101}$ Nor

94. Mass. GEN. Laws ch. 208, § 34 (2012).

95. Kindregan, supra note 75 , at 15 .

96. Id. at 18 .

97. The factors to be considered are the following:

[L] ength of the marriage; age of the parties; health of the parties; income, employment and employability of both parties, including employability through reasonable diligence and additional training, if necessary; economic and non-economic contribution of both parties to the marriage; marital lifestyle; ability of each party to maintain the marital lifestyle; lost economic opportunity as a result of the marriage; and such other factors as the court considers relevant and material.

Ch. 208, §53(a).

98. Professor Kindregan's notes elaborate a little on each of these factors, but they do not discuss caregiving. See Kindregan, supra note 75 , at $37-38$ \& nn.132-41.

99. Drapek v. Drapek, 503 N.E.2d 946, 950 (Mass. 1987) (quoting Mass. GEN. LAws ch. 208, $\S 34(1984)$ ). A homemaking contribution is still relevant to a property award. See ch. 208, §34.

100. See ch. 208, §53(e). Nor do Professor Kindregan's notes mention caregiving as a factor in this context. See Kindregan, supra note 75, at 39-40 \& nn.149-57.

101. See Kindregan, supra note 75, at 35-36 \& n.124. 
is there any entitlement to a market worker's enhanced earning capacity. Instead the emphasis is on economic need. While "reimbursement alimony" 102 potentially affords a caregiver access to the other parent's enhanced earning capacity, a caregiver must have been married less than five years to qualify for this type of alimony ${ }^{103}$ (as well as for transitional alimony). ${ }^{104}$ Reimbursement alimony is limited to recently married couples because these couples are the most likely couples to have an insufficient amount of property accumulated for compensating a spouse's contribution. ${ }^{105}$ Of course, couples married longer than five years might also have inadequate property available for compensatory purposes, but the statute draws a bright line regarding eligibility.

Third, and very importantly, post-marital caregiving is ignored as a reason for compensation; it is potentially relevant only to general term alimony. Reimbursement alimony only reimburses for marital contributions; ${ }^{106}$ it does not address a caregiver's future contributions to the other parent's prosperity through caregiving. "Rehabilitative alimony" is available for one who can "become economically self-sufficient by a predicted time." ${ }^{107}$ Its focus is not on compensating caregiving, but rather helping one transition away from caregiving to paid work. "General term alimony" is available for one who is "economically dependent,"108 and future caregiving may justify economic dependence. ${ }^{109}$ However, the Massachusetts's statute lacks a provision, like in the UMDA, that says a court can excuse a recipient's lack of labor force participation when the recipient is caregiving. A caregiver's eligibility for general term alimony is made even more ambiguous because the statute allows a court to impute income to a caregiver, ${ }^{110}$ and its express inclusion of rehabilitative alimony, with no exemption for caregivers, makes a caregiver's continued economic depen-

102. "Reimbursement alimony" is "to compensate the recipient spouse for economic or noneconomic contribution to the financial resources of the payor spouse, such as enabling the payor spouse to complete an education or job training." Ch. 208, § 48. It is not for support but is compensatory. See Kindregan, supra note 75 , at 25 n.56. It is not modifiable. See ch. 208, $\$ 51(\mathrm{~b})$.

103. See ch. 208, § 48 .

104. "Transitional alimony" is "to transition the recipient spouse to an adjusted lifestyle or location as a result of the divorce." Id. It is only available if the recipient has been married less than five years. See id. It is essentially meant to help the recipient get back to a premarital standard of living after a short marriage. See Kindregan, supra note 75, at 36 . It terminates within three years of divorce. Ch. $208, \S 52(\mathrm{a})$. Transitional alimony is clearly not designed to help a caregiver "transition" to a life of caregiving without simultaneous market work.

105. See Kindregan, supra note 75, at 35 .

106. The contribution must have been made to the "payor spouse," and after divorce neither party contributes anything to a "spouse," since the parties are divorced. See ch. 208, § 48.

107. Id.

108. Id.

109. See, e.g., Kelley v. Kelley, 835 N.E.2d 315, 317-22 (Mass. App. Ct. 2005) (sixteen-year marriage).

110. See ch. 208, §53(f). 
dence on the other parent questionable. Although rehabilitative alimony had previously been viewed suspiciously by the Massachusetts courts, one court recently observed that the reform legislation specifically provides for it. $^{111}$

Fourth, even if a caregiver might receive alimony for her post-divorce caregiving, the law imposes some strict time limits on the alimony's duration, unless a deviation is required in the interests of justice. For a marriage lasting between five and ten years, general term alimony shall continue "for not longer than 60 percent of the number of months of the marriage." 112 Only if the marriage lasted more than twenty years is indefinite alimony expressly permissible. ${ }^{113}$ A caregiver who divorces after six years of marriage is entitled to only about forty-three months of general term alimony (seventy-two months multiplied by sixty percent). If the caregiver has a two-year-old child at the time of the divorce, the child will be less than six years old when the general term alimony ends. Moreover, rehabilitative alimony is presumptively limited to five years. ${ }^{114}$ While the statute allows a court to delay the beginning of alimony until the conclusion of child support payments, ${ }^{115}$ the relevant provision does not appear to extend the alimony time limits otherwise, although as one commentator said, "the meaning of this provision is far from clear."116

Fifth, the statute caps the amount of alimony someone can receive and thereby potentially undercompensates the caregiver. With the exception of reimbursement alimony (for which someone married more than five years is ineligible and which only focuses on marital caregiving), alimony is not supposed to "exceed the recipient's need or 30 to 35 percent of the difference between the parties' gross incomes established at the time" the alimony order is entered. ${ }^{117}$ While a court can deviate from this limit, ${ }^{118}$ the numerical formula sends a powerful message. Even if a parent will perform one-hundred percent of the caregiving going forward, the caregiver is not entitled to half of the other parent's income as a presumptive matter. In addition, the cap is calculated at the time of divorce, so a caregiver will never recover for her labor's enhancement of the other parent's income over the coming years. In fact, the law expressly excludes as a reason to modify an order the fact that the obligor has additional income from a second job or overtime, so long as that additional source of

111. See Kowalska-Davis v. Davis, No. 10-P-2191, 2012 WL 602770, at *1 n.5 (Mass. App. Ct. Feb. 27, 2012).

112. Ch. 208, § 49(b) (2).

113. See id. $\S 49$ (c).

114. See id. $\S 50(\mathrm{~b})$. It may be extended for unforeseen compelling reasons if it would not cause an undue burden on the payor. See id. $\$ 50(\mathrm{~b})(1)$, (3); Kindregan, supra note 75 , at 34 .

115. Ch. 208, §53(g).

116. Witmer \& Warner, supra note $14, \S 9.6$.

117. Ch. 208, §53(b).

118. Id. 
income was acquired after the entry of the initial order. ${ }^{119}$ This bar exists even if the obligee's disproportionate caregiving is the reason the obligor could earn the additional income.

Sixth, both general term alimony and rehabilitative alimony end if the caregiver enters a new relationship. Not only does it terminate when the recipient remarries, ${ }^{120}$ but the 2011 reform also specifies that general term alimony would terminate upon cohabitation with someone for three months or longer, ${ }^{121}$ so long as the cohabitants have a "common household." ${ }^{22}$ It is irrelevant if the cohabitants do not share a life together as a couple, or if the cohabitant has no legal obligation, or desire, to support the caregiver. ${ }^{123}$

In sum, the segmentation of caregiving into time periods helps show the gaps and inadequacies in the law. When the romantic relationship ends, most states only provide a remedy for a caregiver's past caregiving so long as the parties were married at the time. Even divorcing caregivers, however, may encounter an inadequate remedy for marital caregiving if the couple lacks much property, and the judge employs alimony reluctantly to address the injustice. Unwed caregivers typically lack any remedy at the end of their romantic relationship to address the unfairness attributable to past caregiving. Future caregiving, whether by divorced or unmarried individuals, will typically also be uncompensated. Recent reform efforts in some places will hamper judges' ability to use alimony to afford divorcing caregivers an adequate remedy for future caregiving.

The law should tie the remedies for disproportionate and unfair caregiving to the act of caregiving and not to marriage. The costs of caregiving and the benefits conferred by caregiving do not differ depending upon whether the parents are unmarried, married, or divorced. The law should provide a remedy to any parent that provides disproportionate and unfair caregiving. Such is necessary to deter parents from taking advantage of the caregiving parent. ${ }^{124}$

\section{The Incompleteness and Rigidity of Reform Proposals}

Family law scholars have recommended that the law in the United States change to better recognize caregivers' efforts. Proposals have been made to both expand the categories of caregivers who are eligible for awards and to better address post-divorce caregiving. One important ef-

119. Id. $\S 54(\mathrm{~b})$.

120. See id. $\S \S 49(\mathrm{a}), 50(\mathrm{a})$. This applies to general term and rehabilitative types of alimony.

121. See id. $\S 49(d)$; Kindregan, supra note 75 , at 31 . Remarriage and cohabitation rules do not apply to reimbursement or transitional alimony. See ch. 208, $\S \S 51,52$.

122. Ch. 208, § $49(d)$.

123. See Kindregan, supra note 75, at 31 n.94, 32.

124. See June Carbone, Income Sharing: Redefining the Family in Terms of Community, 31 Hous. L. Rev. 359, 405-06 (1994). 
fort is found in the ALI Principles. ${ }^{125}$ Other recent and important contributions include the works of Professors Ayelet Blecher-Prigat and Cynthia Starnes. ${ }^{126}$ Despite the fact that all of these reform proposals would move the law forward if adopted, these reform proposals are uniformly problematic in two ways: first, the proposals do not apply to all caregivers; and second, the proposals try to limit judges' discretion.

\section{A. The ALI's Proposal and Its Problems}

The ALI Principles use three tools to remedy the unfairness that caregivers experience: a child support supplement, a property award, and a spousal support award upon divorce. All of these awards, even together, fail to provide a complete remedy for all caregivers. In addition, the ALI Principles lack any sort of coherent normative message that all parents have an obligation to the other parent to share the costs of caregiving fairly. In fact, the ALI Principles send the opposite message because of the eligibility requirements for its three awards.

Many parents are ineligible for the property and spousal support remedies because these require either a marriage or a domestic partnership. The ALI Principles define domestic partners as two people who "for a significant period of time share a primary residence and a life together as a couple." 127 Couples with a "common child" who maintain "a common household" for a "cohabitation parenting period" also have a domestic partnership. ${ }^{128}$ The state sets the length of the "cohabitation parenting period," but the drafters implied that a two-year period would be a reasonable choice. ${ }^{129}$ The requirement that the individuals share a "primary residence" is meant to exclude "casual and occasional relationships, as well as extramarital relationships conducted by married persons who continue to reside with a spouse." ${ }^{30}$ Of course, this formulation will exclude many couples who have children but who do not cohabit or will not cohabit for the requisite period of time. The child support supplement covers a wider array of parents but nonetheless excludes many categories of caregivers, and it is quite limited in the amount of relief it confers, as described below.

125. See generally Principles. The provisions in the American Law Institute's Principles are heavily influenced by Professor Ira Ellman's earlier work, The Theory of Alimony. See generally Ira Mark Ellman, The Theory of Alimony, 77 CAL. L. Rev. 1 (1989).

126. Ayelet Blecher-Prigat, The Costs of Raising Children: Toward a Theory of Financial Obligations Between Co-parents, 13 Theoretical InQuiries L. 179 (2012); Starnes, supra note 93, at 238.

127. Principles $\S 6.03(1)$.

128. Id. $\S 6.03(2)$.

129. Id. $\S 6.03 \mathrm{cmt}$. d.

130. Id. cmt. c. 


\section{Child Support Supplement}

The ALI Principles' child support supplement is designed so that parents, whether married or unmarried, ${ }^{131}$ share the caregiver's loss of earnings from "appropriate[ ] limits [on] market employment in order to provide care for a child."132 The caregiver's loss is calculated as the difference between what the caregiver would earn in full-time employment and what the caregiver does earn (or would earn) in employment consistent with the child's needs. That loss is allocated between the parents in proportion to their full-time incomes, unless that would be "inequitable."133 The drafters of the ALI Principles made the child support supplement available to all caregivers, regardless of marital or cohabitation status, by attaching it to child support. ${ }^{134}$ Broad eligibility advances thought on this topic considerably, although the ALI's child support supplement is not a panacea.

As an initial matter, the remedy does not permit all caregivers to recover their losses. If the caregiver works full-time, she is ineligible for the remedy even if caregiving "foreclose[s] more lucrative employment opportunities." 135 So, a full-time store clerk cannot recover her loss even though she rejected a higher paying management position because the position's inflexible hours would have interfered with her care for their child. In addition, certain caregivers may not benefit from the remedy because they are outside of a category that makes it "presumptively" permissible to limit market employment: when the child is under three; when there are three or more children under ten; when the child is disabled; or, when the cost of child care is more than the parent's expected earnings. ${ }^{136}$ Even a caregiver that benefits from the presumption may receive nothing if her care is "inappropriate or excessive in terms of the child's needs." 137 Parental care is not automatically deemed more appropriate than day care for children in these categories that trigger the presumption. That parental care can be "inappropriate" or "excessive" for a two year old is arguably an outrageous proposition. Nor need any weight necessarily be given to an earlier parental agreement that parental care would occur. Consequently, if a caregiver can access employment with "on-site

131. Id. $\S 3.01 \mathrm{cmt}$. b.

132. Id. $\S 3.052 \mathrm{~A}(1)$.

133. See id. $\$ 3.052 \mathrm{~A}(5)-(6)$.

134. See id. $\S 3.052 \mathrm{~A} \mathrm{cmt}$. a. By moving and relabeling the provision, it became subject to the principle that a parent's support obligation to the child does not depend upon the parent's legal or social relationship to the other parent. See $i d$. $\$ 3.01 \& \mathrm{cmt}$. b. One of the objectives of Chapter 3 is to treat residential parents fairly and to ensure that "child-support rules take into account a child's need for care.” Id. §3.04(3), (6).

135. Id. $\S 3.052 \mathrm{~A} \mathrm{cmt.} \mathrm{d.}$

136. See id. $\S 3.052 A(2)$. These are not the only times when a child may need parental care, but the other situations will not benefit from a presumption. See id. $\S 3.052 \mathrm{~A} \mathrm{cmt.} \mathrm{b.}$

137. Id. § $3.052 \mathrm{~A}(3)$. 
child care," for example, then her effort to limit market employment may be inappropriate, and her caregiving "excessive," 138 despite the facts that her child is an infant and the parties' previously agreed that in-home care was desirable.

Moreover, the court need not allocate the caregiver's loss proportionally between the parents if it would be "inequitable to do so." The ALI Principles state that it is inequitable to share the loss if the caregiver makes much more money than the market worker. ${ }^{139}$ It is unclear at what precise income level it would be considered "equitable" for the market worker to contribute. It is also unclear why the disparity of income should relieve a parent of all financial responsibility if he can otherwise afford it. Imagine a situation in which the primary caregiver works part-time for $\$ 125,000$, although she could earn $\$ 175,000$ if she only had to shoulder half of the child-care responsibilities. Why should a father who earns $\$ 75,000$ working full-time be absolved of all responsibility for the caregiver's loss?

Additionally, the child support supplement provides payment only for a very short period of time, even if a caregiver qualifies for it. ${ }^{140}$ Compensation is presumptively available only until a child turns three (if the child is an only child). ${ }^{141}$ No remedy is likely for the caregiver's wage loss throughout the remainder of the child's minority. Even during the first three years of the child's life, the remedy is a narrow one: it "reaches only certain current costs of reduced labor-force participation." ${ }^{142}$ It excludes, among other things, "nonaccrual of work experience, seniority, and Social Security coverage." 143

Finally, this supplement is part of child support and not an award to the caregiver for her own use. Although the supplement is meant to compensate the caregiver for her injury, the recovery is technically her child's. Consequently, the caregiver's spending is subject to some limits, ${ }^{144}$ and she may have to account for the money. ${ }^{145}$

Given the limited scope of the child support supplement, the ALI Principles provide two additional methods of compensating a caregiver for caregiving, at least for a caregiver who was married or in a domestic partnership. At the end of a marriage or a domestic partnership, the caregiver

138. See id. $\S 3.052 \mathrm{~A} \mathrm{cmt.} \mathrm{c.}$

139. Id. $\S 3.052 \mathrm{~A}$ illus. 4. A remedy in this situation would be "inequitable." See id. $\$ 3.052 \mathrm{~A}$.

140. See id. §3.052A cmt. d.

141. See id. cmt. c.

142. Id. cmt. d.

143. $I d$.

144. Cf. Deborah H. Bell, Child Support Orders: The Common Law FrameworkPart II, 69 Miss. L.J. 1063, 1076 (2000) (noting that parent recipient of child support is fiduciary for child and cannot compromise obligation by contract).

145. See, e.g., Mo. Rev. Stat. § 452.342 (2011). 
may qualify for an enhanced share of the marital property or for a compensatory spousal payment. ${ }^{146}$

\section{Property}

The drafters of the ALI Principles proposed a "rough compromise" between the competing approaches courts presently employ to allocate marital property, ${ }^{147}$ whether that is "in proportion to the spousal contributions to its acquisition [or] . . . according to relative spousal need."148 The ALI's approach is to award a presumptively equal amount of marital property to each party, with departures allowed to compensate for recognized losses. ${ }^{149}$ The remedy is grounded in the idea that the spouses contribute "to the entire marital relationship, not just to the accumulation of financial assets," 150 and domestic labor permits "the couple to raise children as well as accumulate property." 151 The drafters felt it was reasonable to adopt a presumption of equal contribution to the financial assets because "no-fault divorce [permits] either spouse [to] unilaterally terminate the marriage ... . [if he or she] believe[s] their relationship is seriously one-sided...."152 Since the presumption of equal division can be rebutted to compensate for recognized losses, a caregiver might receive a larger award of property to compensate for her earning capacity loss attributable to marital caregiving. Not all couples have enough property to cover the caregiver's loss, however. ${ }^{153}$ Therefore, the drafters also devised compensatory spousal support, which one scholar has described as "a residual claim" that fills in the gaps left by the property division and child support awards, ${ }^{154}$ but which—as described next-is a key mechanism in its own right for addressing caregiver losses.

\section{Compensatory Spousal Support}

The ALI Principles authorize caregiver compensation in the form of compensatory spousal support to married caregivers and domestically partnered caregivers. ${ }^{155}$ Compensatory spousal support is a claim of entitlement and is not based on need. ${ }^{156}$ The award is justified because the "the cost of raising the couple's children is their joint responsibility." 157

146. See Principles $\S 4.09(2)$.

147. See id. $\$ 4.09 \mathrm{cmts}$. a \& b.

148. Id. cmt. a.

149. See id. $\S 4.09(1)$, (2) (a).

150. Id. $\$ 4.09 \mathrm{cmt}$. c (emphasis added). The presumptively equal division of marital property "follows from the sharing premise." See id. cmt. b.

151. Id. $\mathrm{cmt}$. c.

152. Id. (emphasis added).

153. See id. $\$ 5.10 \mathrm{cmt}$. b.

154. See Carbone, supra note 1 , at 57.

155. See Principles $\$ \S 5.03,6.06$.

156. Id. $\$ 5.02 \mathrm{cmt}$. a.

157. Id. $\S 5.05 \mathrm{cmt}$. a. 
The remedy is specifically designed to compensate caregivers for the earning capacity losses experienced from disproportionate caretaking during the marriage. ${ }^{158}$ The ALI's remedy addresses the caregiver's frustrated expectation that she would share the obligor's income in foregoing her own earning capacity. ${ }^{159}$ The ALI Principles also contain other bases for a compensatory award, and a caregiver might qualify on one of those alternative grounds too; however, the one just discussed is the only one that focuses on caregiving per se. ${ }^{160}$ Adoption of the ALI Principles would be a significant legal advance for caregivers because the Principles make explicit that caregiving causes the caregiver loss and that loss should be compensable as part of spousal support.

The ALI Principles include a formula for computing compensatory spousal support. ${ }^{161}$ Others have called the formula a "pragmatic solution" because assessing the precise earning loss would be quite difficult. ${ }^{162}$ Essentially, the caregiver receives the difference between the non-caregiver's and the caregiver's incomes at dissolution multiplied by a factor that reflects the length of time that the caregiver cared for the children. ${ }^{163}$ This measure supposedly calculates the approximate value of the caregiver's loss because she likely married someone from a similar socio-economic background; therefore, the caregiver could have earned a similar amount as the breadwinner, at least theoretically. ${ }^{164}$ The formula, however, does not permit the caregiver to achieve income equality with the other parent.

158. Id. $\$ 5.02(3)(\mathrm{a}), \S 5.05 \& \mathrm{cmt}$. a.

159. Id. $\$ 5.06 \mathrm{cmt}$. b. The importance of the caregiver's expectation is reiterated in other parts of the commentary. See, e.g., id. $\$ 5.05 \mathrm{cmt}$. e (explaining choice of "proxy measure" to calculate earning-capacity loss); $i d$. $\$ 5.05 \mathrm{cmt}$. a. Similar language is found again in an academic article by one of the Reporters. See Katharine T. Bartlett, Saving the Family from the Reformers, 31 U.C. DAvis L. REv. 809, 847 (1998) ("[The provision] takes sacrifice seriously and encourages it by treating it fairly. It assumes that when different roles led to disproportionate individual earning capacities, it was expected that those shared roles were part of a shared enterprise rather than a lop-sided bargain favoring one partner over the other.").

160. For example, the ALI Principles permit recovery for a loss in a spouse's standard of living if the marriage was of significant duration and the claimant has less earning capacity or wealth. See Principles $\$ 5.03(2)(a)$.

161. See id. $§ 5.05(4)$.

162. See Carbone, supra note 1 , at 69 .

163. The award is the difference between the incomes of the spouses at dissolution, multiplied by a percentage, entitled the "child-care durational factor," which represents the period during which "the claimant provided significantly more than half of the total care that both spouses together provided for the children.” PrINCIPLes $\$ 5.05(4)$ (a). The award is to be a periodic payment with an indefinite duration, if the claimant is old enough and the marriage long enough, but otherwise with a fixed duration for "the length of the child-care period multiplied by a factor specified in the rule." See id. §5.06(1)(a)-(b). The award is meant to end when the loss is compensated, i.e., "the obligee will, after the specified period, have recovered all lost earning capacity." $I d$. $\$ 5.06 \mathrm{cmt}$. b. It can be a lump sum. See id. $\$ 5.10(2)$ (c).

164. See id. $\$ 5.05 \mathrm{cmt}$. e. 
The obligor is never required to pay the caregiver more than forty percent of the difference between the two incomes. ${ }^{165}$

The ALI's approach to spousal support is susceptible to a number of criticisms even apart from the fact that it explicitly requires a marital or domestic partnership before it is available, and it never permits income equality. First, a caregiver is only eligible for this remedy if her earning capacity at divorce is "substantially less than that of the other spouse."166 If her earning capacity is the same or slightly less than her spouse's, it is irrelevant that the caregiver's earning capacity is lower than what it otherwise would have been without the caregiving responsibilities.

Second, a presumption of entitlement exists only if the claimant provided "substantially more than half of the total care that both spouses together provided for the children." 167 This requirement gets at the notion of disproportionality, but it excludes some worthy claimants and creates inequities. For example, a caregiver who does slightly more of the caregiving than the market worker but never shares in any of his income may face more injustice than someone who does a substantial amount of caregiving but fully shares in her partner's wealth.

Third, and very importantly, the remedy does not compensate for future loss caused by post-dissolution caregiving. ${ }^{168}$ By using the market worker's income at dissolution and the years of caregiving during the marriage, ${ }^{169}$ the caregiver's remedy is addressed to the effects of marital caregiving, not the effects of post-divorce caregiving. As already discussed, the child support supplement can compensate for the effects of some postdissolution caregiving so long as the caregiver does not work full-time or earn much more than the other parent, but the supplement typically is

165. See id. $\$ 5.03 \mathrm{cmt}$. b; Starnes, supra note 93, at 237 .

166. Principles $\S 5.05$ (2) (c); see also id. $\S 5.05 \mathrm{cmt}$. d. This is so even though the Reporters acknowledge that "some may have a loss." Id. Why?

[I] t would be contrary to existing law virtually everywhere to require the less affluent spouse to compensate the wealthier one, particularly if their income gap is large. One could argue that allowing these claims would give lower-earning spouses an incentive to fulfill the primary-caretaker role in order to avoid potentially devastating liability at dissolution, and would in this way encourage a more efficient allocation of household duties. But the most efficient allocation may not be the best one, all things considered, so it is unclear whether the law should attempt such an impact on spousal choices. And it is far from clear that such a rule would in fact influence marital behavior, and if it did not the result would be large awards against spouses who cannot afford to pay them. On balance, therefore, such claims are not allowed.

$I d$. The rule is touted for administrative reasons, and the Reporters acknowledge that it "is not entirely consistent with the section's basic rationale." See id.

167. Id. $\$ 5.05(3)$.

168. The Reporters acknowledge that the section "does not compensate the loss of earnings incurred by the spouse unable to realize the value of his or her earning capacity because of post-dissolution custodial responsibilities." Id. $§ 5.05$ cmt. f.

169. See id. $§ 5.05(4)$. 
only available for a very limited time. The clean-break philosophy is still embedded within the ALI Principles, and compensatory spousal support is an example of it. ${ }^{170}$

Fourth, the compensatory spousal support award typically terminates on remarriage or when the recipient enters a domestic partnership. ${ }^{171}$ While spousal support typically terminates on remarriage, it makes little sense when the award is not premised on need, but on compensation. When an award is premised on need, the law assumes that any new spouse will meet the recipient's need. However, when the award is premised on compensation, the award is akin to a payment for a debt owed for work done. The caregiver's new relationship should not extinguish a compensatory award, just as it would not extinguish any other debt.

The ALI's approach to remarriage, just like the current law in most places (including Massachusetts), imposes the costs of caregiving on a legal stranger to the child. It essentially shifts responsibility for the caregiver's financial loss from the child's other parent to the caregiver's new spouse. A second husband will be obligated to pay compensatory spousal support if his wife cared for a non-joint child during their marriage and she suffered a loss of earning capacity. ${ }^{172}$ The ALI justifies this financial allocation by explaining that " $[t]$ here is no basis for imposing [the loss] on the noncustodial parent, who is not generally responsible for voluntary earning-capacity losses incurred by his or her former spouse after the end of their marriage." 173 But that, of course, is the point: the law should provide a basis to make the noncustodial parent an obligor for the caregiver's loss related to the care of their child.

Fifth, the ALI's remedy will fail to remedy some caregivers' frustrated expectations, even though addressing frustrated expectations is one of the goals of the remedy. Married and domestically partnered caregivers are not the only caregivers who rely on the availability of the other parent's income in foregoing their own. An unmarried caregiver, for example, may expect to share the other parent's income because the parties cohabited (albeit too briefly to become domestic partners), and/or were actually sharing, and/or had an agreement to share (even if not a legally enforceable agreement). The ALI Principles foreclose a more factually intensive inquiry that could address all caregivers' frustrated expectations.

The ALI Principles also foreclose the use of alternative legal theories as a basis to afford a remedy, although other theories might sometimes

170. The award is modifiable if the loss upon which the order was based "is substantially smaller than was expected . . . because of an increase in the obligee's income." Id. \$ 5.08(1)(b).

171. See id. $\$ \S 5.07 \& \mathrm{cmt}$. a, 5.09. Joan Williams raised many of these and other criticisms to Ira Ellman's initial proposal to compensate women for financial loss by measuring their earning capacity loss, and the ALI Principles addressed some of her concerns. See Williams, supra note 90, at 2254-57.

172. See Principles $§ 5.05(1)$.

173. Id. $\$ 5.05 \mathrm{cmt}$. b. 
better remedy injustices than the ALI Principles. Loss theory undergirds the ALI's remedy, but, as explained below in Part V.C, it is not the only approach to compensatory payments. Sometimes another remedy might be more appropriate given the facts of the case. Consider the married caregiver who never experienced any economic loss from her ten years of caregiving because she was market challenged (i.e., she had low skills and would have never advanced beyond an entry-level position even without a child). Nonetheless, her caregiving allowed the other parent to experience a financial or other benefit, and he will continue to benefit from her labor in the future. Imagine also that the couple has little property to divide. The absence of a remedy under the ALI Principles means that the Principles permit morally problematic freeloading.

For unknown reasons, the rules in the ALI Principles on alimony and child support have not caught on among the states. ${ }^{174}$ To the extent they have, states sometimes incorporate only the worst aspects of the ALI Principles. Massachusetts is an example. ${ }^{175}$ Most notably, Massachusetts did not amend its child support law to provide anything like a child support supplement when it reformed its alimony law, although it did revise its child support guidelines in 2013. ${ }^{176}$ It also did not broaden alimony eligibility to include domestic partners, or expressly recognize loss theory or the related formula. Instead, perhaps influenced by the ALI Principles' option for a compensatory spousal payment of a presumptively fixed duration, Massachusetts adopted an outer time limit for general term alimony. Like the ALI Principles, Massachusetts capped the percentage that could be awarded after computing the difference between the two parties' incomes; Massachusetts, however, chose even a smaller percentage than the forty percent proposed by the ALI Principles. ${ }^{177}$ Massachusetts followed the ALI Principles in requiring termination of alimony upon remarriage

174. See Lynn Dennis Wardle \& Laurence C. Nolan, United States of America, in 6 International Encyclopaedia of Laws: Family and Succession Law 242 (Walter Pintens ed., 2011) (““[N]o state has yet to formally adopt [those] Principles.' Indeed, a comprehensive 2008 review of the impact of the ALI Principles on family law in the states found that only one state has statutorily enacted any part of the ALI Principles, and the dozen of [sic] so cases each year (average) that cite the Principles do so as an 'obligatory citation' but neither adopt nor rely upon its recommendations." (footnote omitted)).

175. See Kindregan, supra note 75, at 17 (noting Massachusetts "partially incorporated" some of the ALI Principles, but in other places "the text of the Alimony Reform Act of 2011 varies widely from the ALI Principles").

176. Massachusetts did amend its child support law. See Child Support Guidelines, supra note 14. Minimal attention was given to how child support and alimony are related. See id. at 5 . Judges were given discretion to designate child support as alimony if the difference in tax consequences would be more equitable for the child and the parties. See id.; see also Quadrennial Review, supra note 14, at $66-67$.

177. Compare Alimony Reform Act of 2011, Mass. Gen. Laws ch. 208, § 53(b) (2012) ("Except for reimbursement alimony or circumstances warranting deviation for other forms of alimony, the amount of alimony should generally not exceed the recipient's need or 30 to 35 percent of the difference between the 
or cohabitation, although Massachusetts is even tougher on cohabitants. ${ }^{178}$ Finally, neither Massachusetts nor the ALI Principles provide sufficient compensation for post-divorce caregiving.

\section{B. Scholars' Thoughts}

For a long time, scholars who cared about caregivers focused primarily on married and divorcing caregivers when thinking about inter se obligations between parents. ${ }^{179}$ Recently, unmarried caregivers have received more attention from scholars. ${ }^{180}$ Often, however, scholars favor just a subset of unmarried caregivers, and make only that subset eligible for any sort of remedy.

For example, Professor Karen Czapanskiy recently recommended the adoption of "chalimony" for caregivers, and made eligibility independent

parties' gross incomes established at the time of the order being issued."), with PRINCIPLES $\$ 5.03 \mathrm{cmt}$. b (establishing 40 percent difference).

178. Compare Principles $\$ 5.09$ (automatic termination on finding establishment of domestic-partner relationship), with Mass. Gen. Laws ch. 208, § 49(d) (general term alimony "shall be suspended, reduced or terminated" if recipient maintains common household with another for three months).

179. See, e.g., Baker, supra note 82, at 1221; Martha Ertman, Reconstructing Marriage: An InterSEXional Approach, 75 Denv. U. L. Rev. 1215 (1998) (arguing for adoption of Premarital Security Agreements to account for labor done by homemakers); Estin, supra note 85, at 722 (arguing for revitalizing ethic of care and according it recognition at divorce in economic awards); Martha Albertson Fineman, The Social Foundations of Law, 54 Emory L.J. 201, 226 (2005) (suggesting that when marriage with children ends, equal treatment of parties might require that assets should be divided "so that the party who is assuming caretaking responsibilities, usually the mother, is able to maintain a living standard nearly equal to that of the other spouse. Under this theory, one could argue that periodic payments should continue for a substantial period of time to supplement the reduced amount the caretaker will be able to provide in working for pay."); Mary Ann Glendon, Family Law Reform in the 1980's, 44 LA. L. Rev. 1553, 1559 (1984) (recommending "children-first principle" to guide marital property law); Elizabeth S. Scott, Rational Decisionmaking About Marriage and Divorce, 76 VA. L. Rev. 9, 91 (1990) (recommending "more substantial support obligations ... and [ ] property distribution schemes that are beneficial to children"); Singer, supra note 6, at 2454-60 (arguing for income sharing); Williams, supra note 90, at 2255-58 (suggesting equalization of two households' income post divorce, for at least child's minority plus two years); Judith T. Younger, Marital Regimes: A Story of Compromise and Demoralization, Together with Criticism and Suggestions for Reform, 67 Cornell L. Rev. 45, 90-91 (1981) (proposing property rules for married couples with children that would allow court to "delay ultimate property division between parents until all the children reached eighteen"); $c f$. Susan Moller Okin, Justice, Gender, and the FAMILY 170-86 (1989) (recommending greater amounts of child support for unmarried mothers, but not discussing compensation for unmarried mothers themselves).

180. See, e.g., Polikoff, supra note 90, at 26. Professor Polikoff recognizes that "there is no principled basis for restricting support awards today only to husbands and wives" since the " $[\mathrm{c}]$ ontemporary justification for ongoing support after a relationship dissolves rests on the economic consequences of one person forgoing individual financial stability while making uncompensated contributions to a family." Id. 
of marital status. ${ }^{181}$ The award would be in addition to child support and alimony, and would be for caregivers of children with disabilities or chronic illnesses when the child's care impacted the caregiver's labor force participation. ${ }^{182}$ To qualify for a remedy, however, the caregiver's loss must be "beyond the degree common for other caregiving parents."183 In addition, "at least one of the parents ... [must] not be living in the household with the child," 184 and the caregiving must reduce the caregiver's income-earning capacity. ${ }^{185}$ While her proposal has much to commend it, its narrowness is of little benefit to most caregivers and, arguably, even to those in the subset that she is trying to assist.

\section{Limiting the Eligible Claimants}

Others have also limited their proposals to a subset of caregivers, even if marriage is not a prerequisite. Professor Ayelet Blecher-Prigat and Professor Cynthia Starnes have discussed the inadequacies of existing remedies for caregivers and have argued that the parents' relationship to each other as parents should justify a new remedy when one parent alone bears the costs of disproportionate caregiving. ${ }^{186}$ These academics wrote after the ALI's Principles were published and, in some respects, their recommendations are a reaction to the ALI's recommendations. Neither author embraced a remedy for all caregivers who suffer disproportionate and unfair caregiving, however. Both think a remedy should exist only for those caregivers who had a child within an intended, committed co-parenting partnership.

Professor Starnes's latest article focuses primarily on spouses and exspouses, as they had a "mutual commitment to take on the economic support and physical labor required to raise shared children," 187 although she envisions possibly expanding her remedy to "intimate relationships other than marriage that evidence commitment."188 Qualifying relationships might include those with an express contract for a "co-parenting commitment," or relationships that "clearly evidence intimate commitment" even if they lack an agreement. ${ }^{189}$ However, for Professor Starnes, "couples engaged in a one-night stand are clearly not committed and do not enter a co-parenting partnership." 190

181. See Karen Syma Czapanskiy, Chalimony: Seeking Equity Between Parents of Children with Disabilities and Chronic Illnesses, 34 N.Y.U. Rev. L. \& Soc. Change 253, 254, 278 (2010).

182. See id. at 255 .

183. Id. at 264-65.

184. Id. at 265.

185. See id. at 263.

186. See Blecher-Prigat, supra note 126; Starnes, supra note 93.

187. Starnes, supra note 93, at 234.

188. Id. at 237 .

189. $I d$.

190. $I d$. 
Despite a professed willingness to extend her proposal beyond married couples, Professor Starnes's actual willingness appears quite grudging. Her formulation would exclude most non-cohabiting couples who become parents, as well as some cohabiting couples with children. She explains, "[n] or do marriage-eligible cohabiting intimates qualify as committed couples, unless perhaps the circumstances of their relationship trigger a state-imposed status, as the ALI has proposed."191 Most surprisingly, she even excludes some married caregivers from her remedy. Professor Starnes excludes caregivers whose spouses were divided on their desire to add a child to the family, unless they stayed together after the child's birth (potentially evidencing co-parenting commitment), and neither parent rebutted the "rebuttable presumption" of a co-parenting partnership. ${ }^{192}$

Professor Blecher-Prigat similarly limits the availability of her remedy. Professor Blecher-Prigat suggests that the obligations to the caregiver should only apply if the parties are voluntarily joint parents, such as those who "enter into explicit agreements to have and raise a child together."193 She wants the obligations that are imposed by parenthood to be a "choice."194 She therefore limits her remedy to parents who planned to have a child, even for those in a committed relationship such as a marriage. ${ }^{195}$ She appears most concerned about fathers who might be unfairly subjected to obligations, because women alone have the right to abort and, sometimes, to place the child for adoption. She concludes: "My suggestion, then, is that the obligations imposed by a planned shared parenthood and those imposed by unintended parenthood should be different."196 Because unintended conception is so common, ${ }^{197}$ even among married and cohabiting couples, Professor Blecher-Prigat's requirements drastically limit the applicability of her proposal.

Professor Blecher-Prigat and Professor Starnes both choose to emphasize voluntary co-parenting commitment, although they come at the issue of voluntariness differently. "Unintended parenthood" would not bother Professor Starnes so long as the parties both welcomed the child and exhibited some form of co-parenting commitment. Professor Blecher-Prigat, on the other hand, does not differentiate between "intimate committed relationships" and other relationships, but seems only concerned with whether the parties have a planned pregnancy and agree to co-parent.

191. Id.

192. See id. at 238.

193. Blecher-Prigat, supra note 126, at 205-06.

194. Id. at 207.

195. Id. at 207 n.77.

196. Id. at 207 (emphasis added).

197. See Lawrence B. Finer \& Mia R. Zolna, Unintended Pregnancy in the United States: Incidence and Disparities, 2006, 84 CONTRACEPTION 478, 478 (2011) (forty-nine percent of pregnancies in 2006 were unintended and forty-three percent of unintended pregnancies ended in abortion). 
Both authors' formulations are problematic, apart from the fact that they will exclude potentially large numbers of caregivers. Consider first Professor Blecher-Prigat's recommendation, which appears to require both a planned pregnancy and a post-conception agreement to co-parent. Why should a father be relieved of an obligation if both parents intended the pregnancy, but the father absconds shortly after birth, thereby abandoning the child and the mother? Why should the woman's right to abort or relinquish the child for adoption make any difference to the father's obligation if neither party took steps to avoid the pregnancy and the father knows that the law allocates to the mother alone the decision to abort or relinquish the child? Why should a post-birth agreement be necessary if the couple was in a committed, intimate relationship at the point of conception or childbirth, since about half of all pregnancies involve unintended conception? ${ }^{198}$ If "unintended conception" relieves a parent of any obligation to the caregiver, won't there be countless disputes about whether the child was planned or not?

Apart from these questions, Professor Blecher-Prigat's articulation of when the obligation should arise is the wrong result as a matter of theory. Professor Blecher-Prigat rests her case for an obligation only on the parents' consent and then defines consent narrowly. A broader notion of consent would justify imposing the obligation on almost all parents and seems a more defensible line: voluntary sexual relations can be construed as consent to the legal repercussions that follow from the act, including compensation for disproportionate and unfair caregiving. This approach to consent currently justifies the imposition of child support obligations on fathers who claim they never consented to the birth of a child. ${ }^{199}$ In addition, the obligation to give care or share need not be justified solely on grounds of consent. Dependency causation can also support an obligation that is imposed by virtue of parenthood, even when parenthood was "unintended" or achieved without an explicit agreement to have a child. ${ }^{200}$

Professor Blecher-Prigat wants the imposition of an inter se obligation to be fair-an admirable goal. But she fails to realize that "choice" is not the linchpin of fairness; rather, "wrongdoing" is the main component. To see why this is so, compare childbirth that results from a mother who lies to the father about whether she is on birth control, and childbirth that results after a mother forgets to take her birth control. While both acts

198. See id.

199. See Jill E. Evans, In Search of Paternal Equity: A Father's Right to Pursue a Claim of Misrepresentation of Fertility, 36 Loy. U. CHI. L.J. 1045, 1047 (2005) ("Both case and statutory law effectively hold a putative father strictly liable should sexual intercourse result in the birth of a child. Child support obligations attach immediately upon birth, without regard to whether fatherhood was desired or conception occurred through the mother's deceit as to her fertility or use of birth control.").

200. See Marsha Garrison, Is Consent Necessary? An Evaluation of the Emerging Law of Cohabitant Obligation, 52 UCLA L. REV. 815, 826-28 (2005). 
deprive the father of a choice to parent, the latter scenario should not relieve him of his inter se obligation. What differentiates these two scenarios is wrongdoing: parties having sex assume the risk of the innocent or careless mistake, but not the risk of intentional deception.

The importance of wrongdoing becomes even more obvious when one considers rape leading to involuntary parenthood, something not mentioned by Professor Bletcher-Prigat. No one should equate the rapist's actions with the victim's subsequent decision not to abort; yet, under Professor Blecher-Prigat's analysis, both acts are similar. Both parents are subjected to involuntary parenthood, and both would be excused from inter se obligations under her formulation. The mother's parenthood would be involuntary because of the rape, and the rapist's parenthood would be involuntary because of the mother's decision not to abort. Yet only the woman should escape the inter se legal obligations caused by the child's birth in this scenario, and this result requires that one focus on wrongdoing instead of each party's unimpeded choice.

Professor Starnes's formulation is problematic for different reasons. Why is an ongoing commitment between the parents necessary for inter se obligations that address the repercussions of an intimate commitment? Why should a person who voluntarily participates in conception be absolved of responsibility for the costs of caring for the child just because he or she does not stick around? Why should it be a legal anomaly for an unmarried, non-cohabiting couple to have a sufficient intimate commitment to trigger an obligation for caregiver compensation?

A much simpler and better approach would be to create a remedy for all caregivers, regardless of whether or not the couple exhibits committed co-parenting. Apart from the practical problem of how to assess committed co-parenting (a problem illustrated by some of the questions above), requiring committed co-parenting essentially requires parents to opt in to a framework that makes the legal remedy available, and that requirement is unappealing for several reasons.

First, a requirement of committed co-parenting sends the wrong normative message. If the law requires couples to be committed co-parents before they share the costs of caregiving, then the law signals to individuals that freeloading is permissible among other couples. It also signals that it is acceptable for parents to avoid some of the obligations that should attend parenthood and for caregivers to be left without a remedy.

Second, if caregiver compensation is only triggered when parties opt for committed co-parenting, then the law will deter committed co-parenting. For example, some parties may leave the marital residence after the birth to ensure that evidence exists to rebut the inference of a co-parenting commitment. In contrast, if the obligation to give care or share is triggered at childbirth, then the law does not deter a co-parenting commitment because no legal repercussion attaches to the act of becoming committed partners. Rather, an obligation triggered at childbirth would 
incentivize parties to consider the wisdom of reproduction before they reproduce, and that is a good outcome.

Third, an opt-in approach leaves parties vulnerable to their own cognitive errors, including the following: ignorance (couples may not know the consequences of failing to opt in); discounting of risk (couples may assume that a pregnancy will not occur or that they will never split up); and, irrational decision-making in the heat of passion (couples may copulate without discussing the issue of caregiving costs). It also leaves parties vulnerable to advantage-taking, such as when one party falsely represents his or her intention to stick around and help raise a child, but then does not.

Some readers may be wondering about fraud, and whether it is fair to impose the new obligation on someone if the other parent lied about his or her fertility or contraceptive use. In fact, the best solution for fraud is debatable because there are legitimate arguments on both sides. On the one hand, the law rarely allows fraud to excuse the imposition of a child support obligation. ${ }^{201}$ Courts reason that it would be an administrative nightmare to allow fraud to defeat a child support obligation, as allegations of fraud are easy to make and hard to resolve (they are often hesaid/she-said disputes). Courts also reject the relevance of fraud in the child support context because the remedy might diminish the child's receipt of economic support.

These same arguments apply in the context of caregiver payments. The determination of fraud is difficult. The child would suffer if the caregiver's fraud could defeat a remedy. The child is advantaged by caregiver payments because the caregiver shares a household with the child and, together, they constitute "one economic unit." ${ }^{202}$ While imposing an obligation of caregiver payments on a defrauded parent might seem unfair to the defrauded parent, the defrauded parent, rather than the innocent child, should arguably bear the repercussions. The defrauded parent could have used contraceptives to protect against the possibility of the other parent's fraud, or could have abstained from sex until the party's trustworthiness was assured.

On the other hand, making a defrauded parent pay caregiver payments seems more unfair than making that parent pay child support. The equities in the two contexts do differ. Caregiver compensation mainly benefits the dishonest parent at the expense of the defrauded parent, and any benefit to the child is more attenuated than in the child support context. Nonetheless, the administrative difficulties involved in adjudicating fraud still weigh in favor of disregarding fraud altogether in this context, just like allegations of fraud are disregarded altogether in the adjudication

201. See, e.g., Henson v. Sorrell, No. 02A01-9711-CV-00291, 1999 WL 5630, at *4 (Tenn. Ct. App. June 28, 1999) (noting that suits in which father tried to recover damages from mother for false representations concerning birth control have been universally rejected, primarily on basis of public policy).

202. See Principles $§ 7.05 \mathrm{cmt}$. c. 
of child support. This approach also has the advantage of remedying the law's longstanding disregard of fraud at the time of conception that disadvantages caregivers. There is no real legal repercussion for a parent who falsely promised to stick around and help raise a child, especially if he pays child support and maintains some minimal contact with the child. Overall, the caregiver remedy should be available to all caregivers, even those who engage in morally problematic behavior.

\section{Limiting Judicial Discretion}

The works of Professor Blecher-Prigat and Professor Starnes also diverge from this article's recommendation in another important manner. Both authors are committed to limiting judicial discretion. Professor Blecher-Prigat's article is the more problematic of the two in this regard. While the article is incredibly vague about the appropriate remedy for caregivers, it simultaneously dismisses judicial discretion as a means to move the law forward.

While Professor Blecher-Prigat's article argues well for a financial obligation between parents, ${ }^{203}$ she does not propose a specific remedy, nor does she tackle the difficult issues involved in formulating an appropriate remedy. She does, however, acknowledge that the undiscussed issues pose "theoretical dilemmas and practical difficulties."204 The scope of her article prevented her from exploring these complicated issues. ${ }^{205}$ Professor Blecher-Prigat admits that the remedy is the "most significant practical difficultly," and briefly suggests that wage penalty data might help create a formula, but that other childrearing costs "would require further thinking."206 She leaves the reader wondering whether the nonfinancial benefits of childrearing would be part of her formula or not, saying that the question is a "policy decision." 207 She hints that she wants those benefits ignored but gives scant reason to do so. ${ }^{208}$ Her silence on these and other practical issues is unfortunate, both because the devil is in the details and because she needs them resolved before her own proposal can be adopted.

Despite the title of her work, The Costs of Raising Children: Toward a Theory of Financial Obligations Between Co-parents, Professor Blecher-Prigat avoids discussing in detail the appropriate theoretical basis for any particular remedy. She hints that she likes the idea that caretakers might be compensated for losses or supported as they caregive. She makes passing reference to the ALI's approach, although she does not discuss the ALI's

203. See Blecher-Prigat, supra note 126. At bottom, Professor Blecher-Prigat's argues "that joint parents should share the costs of raising their children," as this is a component of co-parenthood. Id. at 190.

204. Id. at 203.

205. See id.

206. Id. at 204.

207. See id.

208. See id. 
caregiver supplement. She presumably would not like the supplement because she disapproves of attaching the remedy to child support: "[C]hild support payments end once the child reaches majority" and the effects of childrearing may impact the parent much longer. ${ }^{209}$

Professor Bletcher-Prigat clearly dislikes using a partnership model (predicated on a romantic or other, non-parental relationship), as a way to determine the scope or content of the parents' obligations to each other. She dismisses it because such a partnership model values the caregiver's labor "only as a contribution to the spousal or partnership relationship." 210 She believes, without explanation or justification, that "[ $\mathrm{t}]$ he obligations that joint parents owe one another should be addressed through the prism of their relationship as joint parents and not as spouses and partners."211 That position seems rather naïve in the specific context of caregiver compensation. After all, caregiving is valuable, at least in part, because it affects the parties' positions as defined within their broader relationship. Also, the expectations related to caregiving can differ dramatically depending upon whether the couple is married or cohabiting, or whether the parents are non-cohabiting friends or strangers. Any agreement between them should be understood in terms of their entire relationship. ${ }^{212}$ The obligation to compensate a parent for caregiving should be sensitive to the other aspects of the parents' relationship. In addition, these other aspects of the parents' relationship matter to the remedy because not all theories for compensation work equally well in all contexts, as shown below.

Despite leaving unresolved all of these difficult issues, Professor Bletcher-Prigat is not willing to give judges discretion to figure out the answers to these questions. Professor Blecher-Prigat rejects this approach by stating, "It is not desirable that the costs of childrearing be legally calculated on a case-by-case basis." 213 The law should establish "presumptive results," rather than use a "discretionary standard." 214 Yet, if lawmakers must develop such presumptive results before they can offer a remedy to even her subset of caregivers (those that have "planned shared parenthood"), then a remedy may not be forthcoming for a long time. Her subset of caregivers encompasses couples with very different relationships and circumstances, and it is debatable whether her "planned shared parenthood" should erase those differences. Certainly, if one wants to make a remedy available for all caregivers, then one cannot forsake a discretionary standard.

Professor Cynthia Starnes does an excellent job of proposing and justifying a remedy, albeit for divorced co-parents, primarily mothers, who

209. Id. at 199.

210. Id. at 190 .

211. Id. at 190-91.

212. See Ellman, supra note 125 , at $30-31$.

213. Blecher-Prigat, supra note 126, at 203.

214. Id. at 203. 
bear the "disproportionate responsibility for the costs of parenting."215 She proposes income sharing for these parents, and she grounds her recommendation in the idea that the couple's entire relationship is a partnership, including the co-parenting. ${ }^{216}$ By emphasizing the notion of partnership, she builds on her earlier work. ${ }^{217}$ Professor Starnes recognizes that her proposal will raise a lot of questions, including "some of them tough ones" that will require future conversations. ${ }^{218}$ She tackles some of them, albeit briefly, including the "appropriate level of income sharing." 219 She gives the nod to the approach found in the ALI Principles. ${ }^{220}$

Professor Starnes, like Professor Blecher-Prigat, rejects giving judges discretion to craft a remedy, although Professor Starnes's position is more subtle: "Whatever level of income sharing is chosen, it should be clear, predictable and widely known, published perhaps in the form of guidelines." 221 Professor Starnes's rejection of judicial discretion is perhaps understandable, given that she has a specific proposal for a specific population. Nonetheless, there are still open issues with her proposal, and giving judges discretion to ensure that the relief is appropriate would be an advantage. Of course, if one wanted to expand her recommendations in any way to reach more couples, then judicial discretion would become a necessity because income sharing is inappropriate for some caregivers, as mentioned below.

In sum, it is unrealistic to seek a formula in this context, at least at the outset, and at least to the extent that one wants to provide a remedy to all caregivers. The requirement that a formula or clear guidelines exist before the adoption of a general caregiver remedy will thwart legal change.

\section{Remedying Disproportionate and Unfair Caregiving}

\section{A. A General Obligation to Give Care or Share}

Judges should be instructed to make the situation between the parents fair when a caregiver experiences unfairness from disproportionate caregiving during the child's minority. Such a broad mandate leaves open the questions of how a court should determine whether unfairness exists and what amount of money would be adequate to redress the injustice.

215. Starnes, supra note 93, at 238.

216. See id. at 232-34.

217. Cynthia Starnes had previously suggested using a "contribution" rationale because the reliance justification casts mothers as "victims of misfortune" and advocated for a continuing award during the wind-up of the partnership. See Starnes, supra note 55, at 1527.

218. See Starnes, supra note 93, at 236.

219. Id.

220. See id. at 237.

221. Id. at 238. 
The next two sections set forth factors and theory that should help judges answer those questions.

Here, first, an explanation is provided about why a general obligation is the right approach. Simply, decades of family law doctrine and policy have made coming up with a simple remedy controversial and difficult. No consensus currently exists even about the appropriate alimony doctrine for divorcing couples. As one legal scholar said in reference to that topic, "reformers cannot agree on principles that will lead to fair outcomes in the majority of cases." ${ }^{222}$ Even the most recent attempts to craft remedies, such as the ALI Principles discussed above, have drawn upon a mixture of rationales and have thrown in some new ones, sometimes in an inconsistent and incoherent manner, but in a way that still has merit. ${ }^{223}$ That hodgepodge was necessary because, as Professor June Carbone put it: "The interests that should be protected at divorce are necessarily multiple, conflicting, and incapable of full reconciliation without sacrificing some for the benefit of others." ${ }^{24}$ Similarly, parties to non-marital co-parenting relationships also exhibit multiple and conflicting interests, in part because these co-parenting relationships are embedded in other relationships of varying types. To make matters even more challenging, alimony theory does not always transfer well to address the situation of non-marital couples that are ending their romantic relationship. In short, the law, reform proposals, and legal theory are not presently at a place that permits a particular solution, such as a formula or uniform approach, for the vast array of caregiving situations.

Unfortunately, the doctrine is not sufficiently settled, nor have opinions sufficiently coalesced, to apply particular theories or approaches to specific categories of caregivers either. In addition, no theory fits well every situation for which it was intended, and empirical evidence is lacking about the merit of particular proposals, especially with regards to their eligibility criteria and their remedies. For example, should the law deny recovery to a caregiver who loses half of her post-divorce income due to her caregiving responsibilities, just because her income exceeds the other parent's income, as the ALI proposal requires? Should an unmarried parent that is abandoned by the other parent and left alone to care for their child have no remedy, just because she was not in a committed relationship at the time of conception, as some current proposals would suggest? If gain theory provides a caregiver with a share of the market worker's post-divorce earning capacity (attributable to the caregiver's post-divorce labor), should that theory be used if the caregiver's infidelity caused the parties to divorce? Answers to these sorts of questions must emerge after

222. See Katharine K. Baker, Homogenous Rules for Heterogeneous Families: The Standardization of Family Law When There Is No Standard Family, 2012 U. ILL. L. Rev. 319, 321 (2012).

223. See, e.g., Carbone, supra note 1 , at 66-67, 70-72 (discussing various rationales and justifications).

224. Id. at 78 . 
judges wrestle with the particular facts of cases, consider the values of a community as embodied in existing law, and consider the policy implications of their answers. The answers are best determined on a case-by-case basis, over time, through judicial reasoning. Only by tackling the many unresolved questions incrementally through the adjudicatory process will all caregivers begin to receive justice.

Fortunately, judges are up to the task of resolving claims for caregiver compensation, despite the unresolved questions. Family court judges are skilled at taking facts and applying them to general principles in order to arrive at "just" outcomes. In fact, judges have exercised similar discretion before, such as when they ordered child support without the benefit of child support guidelines, or currently, when they award an "equitable" division of property, ${ }^{225}$ or an appropriate amount of alimony. ${ }^{226}$ Judges do not require formulas to operate. In fact, judges often want the flexibility to do justice. For example, they seek "wide discretion in choosing the amount and nature of the [alimony] award," even in relatively straightforward cases that focus only on a spouse's need and an obligor's ability to pay. ${ }^{227}$ Many state legislatures recognize that judges need discretion to decide the amount and duration of alimony, in part by refusing to embrace alimony guidelines. ${ }^{228}$ When legislators do give guidelines to judges, judges sometimes ignore them or apply them inconsistently in their quest to do justice. ${ }^{229}$

Embracing the common law method, with all of its uncertainty, will help improve the law. First, it allows judges to gain experience from actual cases, find patterns, develop proxies and presumptions, and move the law along to a better place through experience. Over time, the common law turns patterns into rules and even formulas, as has happened with child support. The actual cases provide the substance and detail that permits appellate courts, and eventually legislatures, to craft limits on judicial discretion. The common law method promotes judicial ingenuity.

225. See Alicia B. Kelly, The Marital Partnership Pretense and Career Assets: The Ascendancy of Self over the Marital Community, 81 B.U. L. REv. 59, 74 (2001).

226. See Baker, supra note 222, at 337 (“[A]ll commentators would agree that alimony remains the least coherent and most discretionary area of family obligation.").

227. Willocks v. Willocks, No. E-2012-00378-COAR3CV, 2013 WL 125927, at *2 (Tenn. Ct. App. Jan. 10, 2013); see also Tismo v. Tismo, No. 91 CA 3, 1991 WL 238190, at*2 (Ohio Ct. App. Nov. 4, 1991); McVey v. McVey, No. 52706, 1987 WL 17891, at *3 (Ohio Ct. App. Oct. 1, 1987).

228. "[No] state has applied a formula to ordinary alimony," and only a few have used them for pendente lite alimony. Alexandra Harwin, Ending the Alimony Guessing Game, N.Y. Times (July 3, 2011), http://www.nytimes.com/2011/07/04/ opinion/04harwin.html. See generally Tiffany Brown, Alimony: A Survey of Formulas, 1 Uтан J. FAм. L. Fall-Winter 2010, at 30-40 (describing formulas used around country).

229. See Baker, supra note 82, at 1195 (describing legal confusion that surrounded factors used to determine alimony awards twenty-five years ago). 
Second, the common law method is the only way that scholars will get a clear sense of a "fair" outcome for all caregivers. No baseline yet exists that establishes fairness for all caregivers. Once actual cases are resolved, patterns will emerge from the varied circumstances. Academics and law reformers can then think about guidelines to help judges become more efficient at their task. The case outcomes will constitute important empirical evidence. Without this first step, the law may ossify instead of develop in a more holistic manner.

Canada provides evidence of the advantage of such an organic lawmaking process. Canada struggled in the alimony context for many years with notions of rehabilitation (to permit a clean break), compensation, and need. Initially, Canadian courts imposed a "broad obligation" on marital and marital-like couples at the relationship's end, but the law lacked "a sense of guiding principles" so that the obligation was "somewhat uncertain and unpredictable in its actual contours."230 Courts applied the standard on a case-by-case basis, making each case subject to the trial court's discretion. ${ }^{231}$ Over time, however, a national set of guidelines emerged that made sense of the courts' decisions, and could address typical cases. ${ }^{232}$ The reformers found patterns in cases between couples with dependent children and those without, came up with a formula, embodied the formula in a computer program, and thereby gave litigants and courts a range of possible awards in both amount and duration. ${ }^{233}$ Now, claimants with children receive compensation (after the payment of child support) both for past caregiving and future caregiving, regardless of the marriage's length. ${ }^{234}$ Typically, the recipient receives an indefinite award of between forty and forty-six percent of the parties' combined net incomes, after child support is deducted. ${ }^{235}$ This award is subject to modification when the youngest child completes high school. ${ }^{236}$

The United States should follow a similar approach to developing guidelines, but the United States should start with an obligation that would apply to all parents. Eventually the case law could provide the foundation for guidelines that would assist with the adjudication of claims for all caregivers.

Despite the reasons that judicial discretion should be embraced as a necessary part of legal reform and as an essential mechanism for affording all caregivers access to a remedy sooner rather than later, judicial discre(2004).

230. Carol Rogerson, The Canadian Law of Spousal Support, 38 FAM. L.Q. 69, 70

231. See, e.g., Bracklow v. Bracklow, [1999] S.C.R. 420, 422 (Can.); Rogerson, supra note 230, at 94 .

232. See Rogerson, supra note 230, at 106.

233. See generally Carol Rogerson \& Rollie Thompson, The Canadian Experiment with Spousal Support Guidelines, 45 Fam. L.Q. 241 (2011).

234. See id. at 256-57.

235. See id. at 256.

236. See id. at 257-58. 
tion makes people nervous. After all, there has been a consistent trend away from discretion in family law over the last half century. Child support is no longer calculated according to a "just and proper" standard, but is set according to guidelines. Child custody is often not determined pursuant to a best interest standard alone, but pursuant to a best interest standard modified by a number of presumptions. In some places, an approximation approach exists that uses the couple's past caregiving pattern to establish the future allocation of custody, at least presumptively. In many places, divorce determinations are no longer made within a faultbased regime, which required courts to determine if fault existed and how much a property award should reflect fault, but are made in a no-fault system coupled with presumptions that a homemaker and market worker each contributed equally to the acquisition of property. Proposals to limit judicial discretion have emerged in the alimony context specifically, ${ }^{237}$ with some recommendations, like those in Massachusetts, becoming law. The ALI Principles are chock-full of formulas and rebuttable presumptions to help achieve consistency and predictability.

For some, judicial discretion is so undesirable that it is better to come up with a formula, any formula, even if it is unfair, inaccurate, or arbitrary. ${ }^{238}$ Formulas are applauded because they provide "quick, stable numbers."239 Stated another way, formulas are valuable because they assure an answer quickly, although sometimes (and perhaps often) the answer is wrong.

People dislike judicial discretion because they equate it with uncertainty, arbitrariness, and inefficiency. ${ }^{240}$ Judges might misapply the various alimony theories. ${ }^{241}$ Or, judicial discretion might "devolve[ ] policy to the predispositions of individual judges." 242 Judges might also undervalue caregiving out of ignorance about its worth, or fail to award much caregiver compensation because they equate it with alimony. The uncertainty associated with judicial discretion may inhibit claimants from invoking the remedy at all: one source reports that the uncertainty surrounding alimony determinations has caused litigants to "forego even attempting to

237. For example, a popular idea is to base a formula on the length of the marriage and the income disparity between the spouses as a way to decide the level and duration of alimony. See Baker, supra note 222, at 359. The American Academy of Matrimonial Lawyers proposed a formula in 2007 that reflects these factors. There are also factors that allow for deviation, including if the spouse is the primary caretaker of a dependent minor. See Am. Acad. of Matrimonial Lawyers, Considerations When Determining Alimony, Spousal Support or Maintenance (Mar. 9, 2007).

238. See Baker, supra note 222, at 361-62.

239. See id. at 362.

240. See id. at 321. It also leads to criticism of the legal system. See Krauskopf, supra note 88, at 276.

241. See Rogerson, supra note 230 , at 95 .

242. Principles $\S 1.01 \mathrm{cmt}$. a. 
secure alimony because bargaining for it is too difficult." 243 Others have mentioned the difficulty lawyers have advising clients about alimony and engaging in "cost-effective settlement negotiations." 244 The unpredictability also means, apparently, that alimony contests are "a disproportionate source of litigation." 245

Although these concerns may be compelling, it is best to evaluate them a little more critically before deciding that a broad general obligation, with its benefits, is untenable. First, a new caregiver remedy might not add delay or uncertainty to proceedings since the available remedies are already described as chaotic. The benefits of expedition, achieved with formulas, may not be essential for this remedy anyway. Expedition is important in the child support context because "so many children and adults [are] dependent on child support," ${ }^{246}$ but no one is yet dependent upon caregiver payments since they do not currently exist. Alimony awards, to the extent that they overlap with caregiver payments, are reported to be few and far between anyway. No reason exists why courts should not award alimony pendente lite and child support while they determine the more complicated remedy for disproportionate and unfair caregiving. This approach should eliminate a major reason to fear delay.

Second, while litigants might experience inconsistent outcomes, this criticism has to be kept in perspective: many claimants would receive nothing at all without a caregiver compensation remedy. Moreover, divergent awards are likely to decline over time with appellate guidance.

Third, the proposal here is not one for unfettered judicial discretion. Decisions ought to rest on the four considerations of fairness set forth below and, primarily, the three compensatory theories that have developed within the context of alimony. These factors and theories should help judges exercise discretion within reasonable limits and permit meaningful review by an appellate court. Courts will have case law, scholarly writing, and policy makers' insights to help guide their decision-making. ${ }^{247}$ In fact, a study that examined the exercise of judicial discretion in the context of alimony awards found that judges' decisions were not determined by the individual proclivities of the judge; rather, identifiable factors predicted outcomes. ${ }^{248}$ The same was found in Canada before the advent of guidelines. ${ }^{249}$ The same should be true for caregiver payments, with certain factors predicting particular outcomes over time.

243. Baker, supra note 222, at 359; see also Elgin, supra note 87 , at 47 ; Rogerson, supra note 230, at 96.

244. Rogerson, supra note 230, at 96.

245. Ellman, supra note 78, at 813.

246. Baker, supra note 222, at 362.

247. See, e.g., Principles $§ 5.03$.

248. See Robert F. Kelly \& Greer Litton Foxh, Determinants of Alimony Awards: An Empirical Test of Current Theories and a Reflection on Public Policy, 44 Syracuse L. Rev. 641, 700-01 (1993).

249. Although Carol Rogerson criticized the unpredictability of Canada's spousal support system with its conflicting rationale before the adoption of guide- 
A discretionary standard also has some real advantages, apart from those already discussed. First, uncertainty as to the size of a potential award can encourage a couple to settle the matter themselves, contrary to the assertion of some scholars who argue that uncertainty necessarily hampers settlement. ${ }^{250}$ People bargain in the shadow of the law. ${ }^{251}$ Uncertainty only harms settlement if the parties have particular risk preferences. ${ }^{252}$ If both parties are risk averse, for example, then uncertainty actually increases the rate of settlement. ${ }^{253}$ When only one party is risk averse, the effect on settlement is hard to predict. ${ }^{254}$ It is only when both partners prefer to gamble that uncertainty fosters litigation. ${ }^{255}$ Even if both parties are gamblers, however, the uncertainty will not tempt them to litigate if the caregiver payment is intertwined with other issues about which one or both of the parties are risk averse. Uncertainty can also increase the rate of settlement if the parties cannot afford to litigate the issue, ${ }^{256}$ and most people in domestic relations litigation, in fact, lack the resources to do so. ${ }^{257}$ Finally, litigiousness declines when people see the remedy as an entitlement that they either expect to receive or pay, ${ }^{258}$ which should be the case with the caregiver remedy.

If history is a guide, then the uncertainty surrounding the precise remedy for disproportionate and unfair caregiving should not hamper settlement. Family law remedies have almost always been clouded by uncertainty, especially in the past. Over thirty years ago, law professors Robert Mnookin and Lewis Kornhauser wrote: "[E]xisting legal standards governing custody, alimony, child support, and marital property are all strik-

lines, she admits that the most problematic cases-that is, the least predictablewere those that are based on need, not compensation, and those typically did not involve relationships with children. See Rogerson, supra note 230, at 98-100. In fact, in some cases, it was easy to discern patterns, especially in long-term marriages where the spouse bore a disproportionate amount of the childrearing responsibility. See id. at 100. While other caregiving relationships produced less predictable results, Rogerson noted increasing judicial attention to the economic costs of ongoing custody responsibility and the children's standard of living in the household. See id. at 102.

250. See Blecher-Prigat, supra note 126, at 203-04; George L. Priest \& Benjamin Klein, The Selection of Disputes for Litigation, 13 J. Legal STUd. 1, 14-16 (1984). 251. See generally Robert H. Mnookin \& Lewis Kornhauser, Bargaining in the Shadow of the Law: The Case of Divorce, 88 YALE L.J. 950 (1979).

252. See id. at 970 .

253. See id. at 976 .

254. See id. at 977. While the "risk preferer" usually has the advantage in negotiations, it is hard to know which parent, if either, would prefer the risk in this context. See id.

255. See id. at $976-77$.

256. Cf. id. at 972 .

257. See Leslie Feitz, Pro Se Litigants in Domestic Relations Cases, 21 J. Am. AcAd. Matrimonial L. 193, 193 (2008); Jona Goldschmidt, How Are Courts Handling Pro Se Litigants?, 82 Judicature 13, 14 (1998).

258. See Craig Martin, Unequal Shadows: Negotiation Theory and Spousal Support Under Canadian Divorce Law, 56 U. Toronto FAC. L. Rev. 135, 153 (1998). 
ing for their lack of precision and thus provide a bargaining backdrop clouded by uncertainty." 259 This uncertainty did not foster litigation, however. It fostered settlement. As Mnookin and Kornhauser explained: "[M] ost divorcing couples never require adjudication for dispute settlement." 260 Rather they settled because they wanted to avoid the risks, uncertainties, and transactions costs. ${ }^{261}$

In addition, any uncertainty about how a court might resolve a claim for caregiver payments may encourage parties to work out these issues themselves before conception or at the outset of parenthood, or to avoid parenthood altogether. Parties can minimize uncertainty by negotiating a solution that will apply to their relationship, assuming that such an agreement is either enforceable or relevant to the court's assessment of an appropriate remedy. This article proposes that a court give weight to any such agreement in its assessment of fairness, thereby giving the parties a strong incentive to work these issues out themselves.

The uncertainty surrounding the remedy also has the benefit of placing the parents in an equal bargaining position when they are negotiating such an agreement. When the litigated outcome is clear and favorable to one of the parties, the other party may have insufficient bargaining power to get an agreement that alters that outcome. Many unmarried caregivers are in such a position presently. An unmarried caregiver is unlikely to convince the other parent to compensate her for caregiving since the caregiver is legally entitled to nothing. However, a caregiver would be more likely to convince the other parent to reach an agreement about sharing if a court were required to provide a remedy for disproportionate and unfair caregiving, and the amount of the remedy was uncertain.

In sum, the world is not going to end if judges are told to remedy disproportionate and unfair caregiving without more specific guidance. The law can and should move forward instead of being stymied by complexity and the desire for simple answers. A discretionary approach is the most pragmatic solution at this time and the only realistic way to achieve a caregiver remedy for all caregivers.

\section{B. The Factors That Make Caregiving "Unfair"}

Judges would have two important tasks when adjudicating a claim for a caregiver remedy. A judge must first determine eligibility for the remedy

259. Mnookin \& Kornhauser, supra note 251, at 969; see also Brinig \& Carbone, supra note 1 , at 904 (discussing alimony); Ellman, supra note 125 , at $4-5$ (same).

260. Mnookin \& Kornhauser, supra note 251, at 974.

261. See id. Admittedly, the authors criticize uncertainty in the context of custody disputes. See id. at 977-80. However, the dynamics involved in custody litigation are entirely different than the dynamics related to a new remedy for economic compensation. It is not clear Mnookin and Kornauser would disapprove of the uncertainty in this context, although they would certainly point out that such uncertainty could increase transaction costs. Id. at 979 . 
and then determine the precise remedy that rectifies the unfairness. A determination that disproportionate caregiving is or was "unfair" is certainly not mechanical. A determination of "unfairness" is highly individualized and requires an assessment of four intertwining factors: (1) the time each parent spends working in the market and the home; (2) the relative allocation of market work and non-market work between the parties; (3) the couple's sharing behavior; and, (4) their agreement, whether explicit or implicit, about their allocation of market and non-market work and their sharing of economic resources.

\section{The Time Each Parent Spends Working in the Market and the Home}

If one parent earns all the income and does all the non-market work (e.g., child care and related housework), and the other parent engages solely in leisure, then the allocation of work between them seems unfair, at least on the surface. Our assessment of fairness might change if we knew that the couple takes turns, i.e., they alternate on a yearly basis who engages in the work activities. Nonetheless, a comparison of the time each parent spends at work or in leisure is useful information, even if we must sometimes enlarge the timeframe to capture what is really happening.

In many cases, comparing the parties' work hours may not unearth much unfairness at all. Most couples do not have very lop-sided arrangements, and enlarging the timeframe does not typically change this fact. Both parents typically work consistently in ways that benefit their child, whether their labor is expended at home, in the labor market, or in both places. Men and women are generally doing about equal amounts of work (approximately eight hours a day on a combination of home and paid work) and have similar amounts of down time. ${ }^{262}$ Even when the focus is on families with children, women still only spend about twenty minutes more a week on work. ${ }^{263}$

Nonetheless, there are some times when caregivers do much more work. When both parents are fully employed and their child is under six, for example, women's total working time exceeds men's total working time by about five hours a week. ${ }^{264}$ In addition, if the mother is the sole

262. See United States: Work-Life Balance, OECD Better Life Index, http://www .oecdbetterlifeindex.org/countries/united-states (last visited Nov. 10, 2013) (" $[\mathrm{M}]$ en are more likely to spend more hours in paid work, while women spend longer on unpaid domestic work. Men in the United States, spend 154 minutes per day cooking, cleaning or caring, more than the OECD average of 131 minutes but still less than American women who spend 258 minutes per day on average on domestic work. ... [B] oth men and women devote approximately 14 hours per day to personal care and leisure.").

263. See Ruth Davis Konigsberg, Chore Wars, Time (Aug. 8, 2011) http://con tent.time.com/time/magazine/article/0,9171,2084582,00.html ("For [married couples] who had children under the age of 18, women employed full time did just 20 min. more of combined paid and unpaid work than men did . . ..”).

264. See id. (reporting "a difference of five hours more of combined paid and unpaid work for women a week" according to data from 2003-2005 among dualearner couples with children under age of 6); $c f$. Pew Research Ctr., Modern 
breadwinner, the combination of her paid work, child care, and housework exceed her partner's workload by an additional twenty-five hours a week; in contrast, if the father is the sole breadwinner, his total workload exceeds his partner's by eleven hours per week. ${ }^{265}$

The amount of leisure each parent enjoys is another way to assess relative contributions. Each party's leisure time is not a mirror image of that party's work time. Leisure time is a residual category and reflects the time that is left after one subtracts all paid and unpaid work, personal care, and transportation time from the twenty-four hours in the day. ${ }^{266}$ Arguably leisure time is an appropriate point of comparison because leisure time strongly affects how one perceives the quality of one's life. ${ }^{267}$

Certain parents have a leisure deficit compared to the other parent. Comparing the leisure time of male and female sole breadwinners, for example, reveals that female sole breadwinners have twenty hours less leisure per week than their partners, and male sole breadwinners have four hours less leisure per week than their partners. ${ }^{268}$ In addition, mothers have much less "uncontaminated leisure" time than do fathers, that is, leisure time apart from other activities such as housework or child care. ${ }^{269}$

Mothers who are single and poor, have custody of their child, and work both inside and outside the home ${ }^{270}$ sometimes have the greatest

Parenthood: Roles of Moms and Dads Converge as They Balance Work and Family 29, 39 (2013) [hereinafter Pew Research Ctr., Modern Parenthood] (finding fathers in dual-income couples spend ten to eleven hours more than mothers in paid work, while women spend about nine hours more per week in household work and child care; additionally, "the gender gap in leisure is about five hours per week"). Married fathers have three hours per week more leisure than the mothers when their children are under eighteen years old, and cohabiting fathers with similarly aged children have about four hours per week more leisure than the mothers. See id. at 7, 41. Leisure time represents time relaxing in various activities. See id. at 7 . While researchers sometimes arrive at different numbers for the amount of time men and women spend engaged in work or leisure, it is not the point of this article to reconcile any discrepancies. For example, according to the Pew Research Center, married men with children under eighteen work 1.4 hours per week more than married women with children under eighteen. See $i d$. at 29. The most accurate assessment of the leisure time enjoyed by particular mothers and fathers would be their time diaries.

265. See Pew Research Ctr., Modern Parenthood, supra note 264, at 6.

266. See, e.g., id. at 46.

267. See Sut Jhally, Commercial Culture, Collective Values, and the Future, 71 TEx. L. REv. 805, 809 (1993).

268. Pew Research Ctr., Modern Parenthood, supra note 264, at 29-30.

269. See Suzanne M. Bianchi et al., Changing Rhythms of American Family LIFE 102-03 (2006).

270. To the extent these lower-income mothers are not working in the labor market, it is often because they cannot find affordable child care for their children. See generally Joan C. Williams \& Heather Boushey, The Three Faces of Work-Family Conflict: The Poor, the Professionals, and the Missing Middle 16-17 (2010) available at http://www.americanprogress.org/wp-content/uploads/ issues/2010/01/pdf/threefaces.pdf. 
leisure deficit of all. ${ }^{271}$ These mothers were recently blamed for the fact that the United States ranks twenty-eighth in the world in the work-life balance, just above Mexico. ${ }^{272}$ Not only do mothers in single-parent households often work more hours in the workforce than employed married women, ${ }^{273}$ but labor-saving devices and life's conveniences may be unavailable to them. ${ }^{274}$ They frequently feel stressed because they are largely going it alone. ${ }^{275}$ Researchers in the Netherlands noted that these mothers "seldom [have] any leisure time."276

The results for couples might change if we include personal time (e.g., time spent eating, sleeping, grooming, etc.) with leisure time, but it is best to exclude personal time. Time spent on these activities is heavily influenced by cultural expectations and physical needs, and can feel less discretionary. Moreover, caregivers' "personal time" often involves simultaneous acts of caregiving. A mother's "personal time" eating and sleeping, for example, is much more likely to be encumbered by her child's presence. A mother, more than a father, is likely to be the one cuddling with the child when the family sleeps. ${ }^{277}$ If one were to focus solely on "adult free time" (free time spent alone or with other adults, but not with children), one finds that mothers have less of it. ${ }^{278}$ As one set of sociologists noted, adult free time is "perhaps the most refreshing kind of leisure."279

271. See Sanik \& Mauldin, supra note 47 , at 56 (noting that single employed mothers sacrifice time in personal care, such as sleeping, and recreation to meet family's needs).

272. See Derek Thompson, How Did Work-Life Balance in the U.S. Get So Awful?, The Atlantic (June 1, 2013), http://www.theatlantic.com/business/archive/ 2013/06/how-did-work-life-balance-in-the-us-get-so-awful/276336/.

273. See Pew Research Ctr., Modern Parenthood, supra note 264, at 41 (comparing paid work between married and single mothers in chart titled "Mothers' Time by Family Structure"); cf. Sanik \& Mauldin, supra note 47, at 55 (reporting single employed mothers spent less time with children than married employed mothers when age of younger child was controlled).

274. See Martha Minow, The Welfare of Single Mothers and Their Children, 26 Conn. L. Rev. 817, 829-30 (1994); cf. Pew Research Ctr., Modern Parenthood, supra note 264, at 41 (noting single mothers spend five hours less doing housework than married mothers and two hours less than cohabiting mothers).

275. Cf. Pew Research Ctr., Modern Parenthood, supra note 264, at 1 (reporting 56 percent of working moms feel stressed about juggling work and family life, as compared to 50 percent of working dads).

276. Wilma Bakker \& Lia Karsten, Balancing Paid Work, Care and Leisure in Postseparation Households: A Comparison of Single Parents with Co-parents, 53 Acta Sociologica 173, 183 (2013). But see Pew Research Ctr., Modern Parenthood, supra note 264, at 41 (indicating that single mothers have several hours more of leisure beyond their married sisters because single mothers spend less time on child care and housework).

277. See Sarah A. Burgard, Jennifer A. Ailshire \& N. Michelle Hughes, Gender and Sleep Duration Among American Adults 16 (Population Studies Ctr., Research Report No. 09-693, 2010), available at http://www.psc.isr.umich .edu/pubs/pdf/rr09-693.pdf.

278. See Bianchi et AL., supra note 269, at 102-03.

279. Id. at 103 . 
Perceptions of fairness tend to correlate with how much market work the caregiver is doing. ${ }^{280}$ Women who are substantial economic contributors tend to object more than other women about the division of household labor. ${ }^{281}$ That makes sense because their partners often have a "leisure surplus," 282 while they suffer a "leisure deficit."

In the overall scheme of things, however, these sorts of time differences are not the biggest component of unfairness that may exist between the parents, although a disparity of five hours a week can seem hugely unfair in the moment. Rather, most of the unfairness relates to the fact that caregiving has negative economic repercussions compared to market work. Many caregivers do not focus on the long-term, negative repercussions of disproportionate caregiving because they assume that they will be treated well by their partners, ${ }^{283}$ they do not know the negative, long-term effects associated with the caregiving role, and/or they realize that no legal remedy exists.

\section{The Relative Allocation of Home Work and Market Work Between the Parents}

Doing more of the non-market work has economic costs that are very real and at times very substantial. Work patterns are frequently gendered. A mere $6.6 \%$ of employed fathers engage in part-time market work, compared to $26.6 \%$ of employed mothers. ${ }^{284}$ For every stay-at-home dad, there are thirty-two stay-at-home moms. ${ }^{285}$

Women typically engage in a higher percentage of household and caregiving activities than men as an overall component of each party's "work." The Bureau of Labor Statistics reports that on an average day, only nineteen percent of men do housework (e.g., cleaning or laundry) compared to forty-eight percent of women. ${ }^{286}$ With respect to child care, mothers with children under six years old spend 1.1 hours providing physical care for their children, but fathers spend only twenty-six minutes doing the same. ${ }^{287}$ Mothers also multi-task more often than fathers, by

280. See Paul R. Amato et al., Alone Together: How Marriage in America Is Changing 154-56 (2007).

281. See id. at 155 .

282. Sara Raley \& Vanessa Wight, The Leisure Surplus of Fathers in Working Families (Aug. 3, 2008) (unpublished paper presented at American Sociological Association Annual Meeting), available at http://citation.allacademic.com/meta/ p_mla_apa_research_citation/2/4/1/2/8/p241289_index.html.

283. See Crittenden, supra note 54, at 89 (2001).

284. Pew Research Ctr., Modern Parenthood, supra note 264, at 37.

285. See U.S. Census Bureau, Census Bureau Reports Families with ChilDREN INCREASINGLy FACE Unemployment (Jan. 15, 2010), available at http://www .census.gov/newsroom/releases/archives/families_households/cb10-08.html (noting 5.1 million stay-at-home moms in 2009 and 158,000 stay-at-home dads).

286. Bureau of Labor Statistics, U.S. Dep't. of Labor, USDL-12-1246, American Time Use Survey-2011 Results 2 (2012), available at http://www.bls .gov/news.release/archives/atus_06222012.pdf.

287. Id. at 3 \& tbl.9. 
caring for their children while engaging in another primary activity, such as cleaning the house. Therefore, a mother with a child under six spends, on average, approximately 6.5 hours per day with her child in tow, while a father spends approximately 4.25 hours per day with his child in tow. ${ }^{288}$ Consequently, despite the total number of hours worked being similar between mothers and fathers, "[w] omen still do twice as much housework and child care as men" in two-parent families. ${ }^{289}$

Even when both parents are employed in the paid workforce, and even when women earn more than half the household income, most husbands do less than a fair share of the domestic labor. In one study, fortyone percent of the men in dual-income households with "higher-earning" wives did "a substantial portion of the domestic labor" (i.e., one-third to one-half of that labor), but approximately fifty-nine percent of these men performed less than one-third of that labor. ${ }^{290}$

When the parents live apart, the unequal allocation of caregiving usually intensifies. Unwed and divorced mothers do huge amounts of caregiving by themselves. Both unmarried and divorced fathers' involvement with their children tends to decline after their romantic relationship with the mothers end. ${ }^{291}$ One set of researchers noted that the father's prior "nontrivial" help with housework and caregiving disappears upon divorce, causing the caregiver to face increased time pressures that go uncompensated. ${ }^{292}$ As a consequence, at the point of family breakup, freeloading can either begin or intensify.

The allocation of domestic labor affects women's work patterns. Regardless of whether a woman is a high or low earner, caregiving affects her market participation. The New York Times reports, for example, that four out of ten female doctors between ages thirty-five and forty-four work parttime, and full-time female doctors work on average 4.5 fewer hours each

288. See id. at 3 \& tbl.10; $c f$. Pew Research Ctr., Modern Parenthood, supra note 264, at 3 (finding that fathers spend approximately seven hours per week on child care and mothers spend approximately fourteen hours per week on child care).

289. BiAnchi ET AL., supra note 269, at 113; see also Bureau of LABOR StatisTICS, supra note 286 , at $3 \&$ tbl.9 (showing women spend approximately twice as much time caring for children as men no matter age of youngest child).

290. See Veronica Jaris Tichenor, Earning More and Getting Less: Why Successful Wives Can't Buy Equality 40-41 (2005) (discussing study comparing division of domestic labor between men and their wives who are "nearly sole breadwinners" or "higher-earning"); see also Edmund L. Andrews, Survey Confirms It: Women Outjuggle Men, N.Y. Times (Sept. 15, 2004), http://www.nytimes.com/2004/ 09/15/politics/15labor.html?_r=0; David H. Demo \& Alan C. Acock, Family Diversity and the Division of Domestic Labor: How Much Have Things Really Changed?, 42 FaM. REL. 323, 326 (1993).

291. See William Marsiglio et al., Scholarship on Fatherhood in the 1990s and Beyond, 62 J. MARriage \& FAM. 1173, 1184 (2000) (mentioning decline in "quality and quantity of contact between fathers and children" after divorce).

292. See Connelly \& Kimmel, supra note 46, at 124. 
week than male doctors. ${ }^{293}$ Almost seventy-five percent of female pediatricians "take extended leave at some point-five times higher than the percentage for male pediatricians." 294

As Part II.B discussed, ${ }^{295}$ the choices reflected in these patterns have real economic consequences. Caregivers suffer economic loss and market workers enjoy economic gains, and these results are enduring. Any assessment of fairness must be informed by the fact that disproportionate caregiving likely has long-term, negative economic consequences for the caregiver.

Parents themselves recognize the unfairness inherent in these patterns. In one national sample of 234 married parents, mothers were more likely to think things were "unfair" to them when fathers "were actually doing less nurturant parenting than the mothers thought was ideal."296 Likewise, fathers believed the labor division was "unfair to the mother" when the fathers reported "doing more breadwinning" than the fathers thought was ideal. ${ }^{297}$ Simply, both parents recognized that when work becomes polarized by gender more than the couple thinks is ideal, the caregiver is the one to experience the unfairness.

\section{The Noneconomic Costs and Benefits}

What about the world of noneconomic benefits that is also associated with non-market work? Some undeniable noneconomic rewards are associated with caregiving, such as emotional satisfaction from comforting one's crying infant or witnessing one's preschooler successfully tie her shoe for the first time. In Dr. Laura Schlessinger's book, In Praise of Stay-atHome Moms, ${ }^{298}$ one woman revealed that she "can't compare" being there for her twenty-month-old daughter's "firsts" "to anything in the world."299 Raising her daughter "is what life is all about."300 Should these noneconomic benefits be considered when assessing whether the parents' allocation of work is unfair? Are caregivers not compensated for their income loss by their children's smiles?

The pleasure from a child's smile should not be underestimated, even if the pleasure-like the smile-is only fleeting. Nonetheless, the noneconomic rewards from caregiving should be ignored in assessing the fairness of the parents' arrangement. No one would deny that these bene-

293. See Karen S. Sibert, Don't Quit This Day Job, N.Y. Times (June 11, 2011), http://www.nytimes.com/2011/06/12/opinion/12sibert.html?pagewanted=all.

294. $I d$.

295. For a discussion of economic consequences, see supra notes 54-60 and accompanying text.

296. Melissa A. Milkie et al., Gendered Division of Childrearing: Ideals, Realities, and the Relationship to Parental Well-Being, 47 Sex Roles 21, 21, 36 (2002).

297. Id.

298. Laura Schlessinger, In Praise of Stay-at-Home Moms (2009).

299. Id. at 137.

300. Id. at 138 . 
fits exist, but they are difficult to measure. The difficulty explains why we say it is "priceless" for a parent to witness his or her child's first steps. The term "priceless" acknowledges the subjectivity involved in valuing the experience. We might try to insert some objectivity into the valuation exercise by asking what a "reasonable parent" would say the experience is worth, but it is a lot easier and more comfortable to conclude that the experience is simply "priceless," precisely because the value of the experience is so individualized. Courts that have been asked to monetize the noneconomic benefits of family life have sometimes refused to do so, reasoning that, "While the benefits of family life may be significant . . . the benefits are intangible and too difficult to measure."301

Valuation becomes even more problematic when its purpose is to offset the amount of economic harm that the caregiver experiences. A caregiver would be put in the uncomfortable position of minimizing her emotional benefits from her child in order to reduce the offset effect. More importantly, the emotional benefits of childrearing do not actually diminish the very real monetary sacrifices associated with the activity. A caregiver cannot put food on the table with the joy that she feels from watching her child score a soccer goal. Comparing noneconomic benefits and economic costs is like comparing apples and cars, not even apples and oranges, because they are truly incommensurable.

Moreover, if noneconomic benefits are relevant to a fairness assessment, then so too are the "noneconomic costs" of caring for children. But it is equally difficult to put a dollar value on the unpleasantness involved in cleaning up after a sick child or the aggravation felt from dealing with a disobedient child. Again, that is not to say that these costs are not real, or in some general sense measureable. In fact, author Diane Ehrensaft documented that the day-to-day burdens of caregiving are particularly great for mothers, even when mothers and fathers are equally co-parenting. ${ }^{302}$ Mothers tend to worry more than fathers. ${ }^{303}$ She explained:

[T] he mother will tend to carry the child around in her head, even when the child is not with her. This can be referred to as the psychological "labor" of childrearing. It embodies thoughts, feelings, and even obsessions about how the child is doing.

The father, in contrast, even in the shared parenting family, appears to feel more separate from his child. ${ }^{304}$

301. Lovelace Med. Ctr. v. Mendez, 805 P.2d 603, 620 (N.M. 1991) (Alarid, J., appended New Mexico Court of Appeals' opinion).

302. See, e.g., Diane Ehrensaft, Parenting Together: Men and Women SharING THe CARe of Their Children 57-75 (1987) (using clothing choices, worrying, and psychological management as examples of greater burdens on women, even in equal parenting relationships).

303. See id. at 65-66.

304. Id. at 67 . 
This disparity existed regardless of the mother's and father's professional obligations. ${ }^{305}$ Consequently, men were better at being "off" when at work, whereas women had their children on their mind throughout the day. ${ }^{306}$

Regardless of whether it is mothers or fathers who experience more of the noneconomic burden of childrearing, these noneconomic burdens (just like the noneconomic benefits) are virtually impossible to monetize. In fact, it makes a lot of sense to assume that caregivers experience an equal amount of nonmonetary costs and benefits and that these nonmonetary components balance each other out. This reasonable assumption means that noneconomic considerations can be ignored in an assessment of fairness. That is a good outcome, because no one wants to go swimming in a swamp.

\section{The Living Arrangement of the Couple}

The parents' caregiving arrangement may not be unfair even if they do not split caregiving equally. The primary breadwinner may be sharing his or her income with the caregiver and the parents may be content with the arrangement. When the parents are living together, each parent is likely benefiting from the other's labor regardless of whether they have agreed to their respective roles and regardless of whether these allocations meet both parents' ideal preferences. In these "sharing" relationships, the market worker is sharing his earnings but typically also his companionship and emotional support, and the caregiver is sharing her caregiving and homemaking, as well as her companionship and emotional support.

Couples' sharing behavior is typically influenced by their marital status, cohabitation arrangement, and romantic relationship, although these three factors are imperfect determinants of it. Selfish behavior sometimes exists between cohabiting spouses, ${ }^{307}$ and generous sharing behavior sometimes exists among unmarried, non-cohabiting, non-dating parents. While couples exist that are exceptions to the general patterns, these proxies are convenient and generally accurate indicators of sharing behavior.

Sharing occurs in most marital and marital-like relationships, in part because that is the societal expectation. Unmarried couples share less than married couples, ${ }^{308}$ although unmarried couples that act like married couples, especially if they have children, are more likely to share than other unmarried couples. Law professor Cynthia Bowman reports that "a majority of both cohabitants and married couples do maintain joint fi-

305. See id. at $67-68$.

306. See id. at 99.

307. See, e.g., McGuire v. McGuire, 59 N.W. 2d 336 (Neb. 1953) (describing husband's treatment of wife, which included refusing to install plumbing or working furnace in home).

308. See Catherine Kenney, Cohabiting Couple, Filing Jointly? Resource Pooling and U.S. Poverty Policies, 53 Fam. Rel. 237, 243 (2004). 
nances," 309 and "virtually all" cohabitants with a common child pool their income. ${ }^{310}$ A romantically-involved couple that lives apart is less likely to be sharing resources than is a cohabiting-married or cohabiting-unmarried couple, but more likely to be sharing than non-cohabiting parents with a platonic relationship. ${ }^{311}$

After the romantic relationship ends, voluntary sharing behavior often ends too, regardless of whether the couple was previously married, cohabiting, or romantically-involved but non-cohabiting. People tend to view themselves as individuals and not part of a couple. For most caregivers, it is as if they receive a pay cut after the romantic relationship ends despite the fact that they are doing the same amount, or more, of the caregiving. Whereas the market worker before shared his income (and some of the day-to-day caregiving labor), now he shares none (or less) of his income and provides no (or little) day-to-day help. The task of caregiving going forward continues to disadvantage the caregiver economically while her efforts continue to benefit the market worker. He gets the services of a nanny par excellence at bargain basement prices, if he has to pay anything at all. He can be the ideal worker and see gains in his earning power. He can have a disproportionate amount of leisure time. He can freeload and the law permits it.

Some might dispute the existence of any unfairness after the couple splits, noting that the market worker's employment typically benefits the couple's child and the caregiver after the couple has broken up. After all, the earnings of the primary breadwinner reduce the caregiver's need to contribute economically to their child. Courts typically allocate child support in proportion to the parents' ability to pay. The argument, therefore, is that the market worker's labor benefits the caregiver even after the romantic relationship ends, just as a caregiver's labor benefits the market worker. Both are carrying a disproportionate burden in their respective spheres.

This argument has appeal until numbers are attached to a scenario. Imagine, for example, that the market worker makes $\$ 62,445$ a year $(\$ 5,204$ per month), the average earnings for a full-time male worker in $2009 .^{312}$ The market worker is required to pay approximately $\$ 804$ per month in child support for one child if the caregiver is unemployed and

309. Bowman, supra note 64 , at 23.

310. See id. at 35.

311. See Ariel Kalil \& Rebecca M. Ryan, Mothers'Economic Conditions and Sources of Support in Fragile Families, Future Child.: Fragile Families, Fall 2010, at 44, 55, available at http://www.futureofchildren.org/futureofchildren/publications/journals/article/index.xml?journalid=73\&articleid=530; Hyeyoung Woo \& R. Kelly Raley, A Small Extension to "Costs and Rewards of Children: The Effects of Becoming a Parent on Adults' Lives," 67 J. Marriage \& Fam. 216, 217 (2005).

312. See U.S. Census Bureau, Statistical Abstract of the U.S.: 2012, Income, Expenditures, Poverty, and Wealth 459 tbl.703 (2012). 
expected to contribute nothing. ${ }^{313}$ If the caregiver were also working in the paid work force, and she earned the average earnings of a full-time female worker in 2009 , or $\$ 44,857$ ( $\$ 3,738$ per month), ${ }^{314}$ then her monthly child support obligation would be $\$ 427$ and his would be $\$ 589$. Consequently, his labor (and his higher payment of child support) arguably benefits her either $\$ 427$ per month (if she is out of the labor force entirely) or $\$ 81$ per month (if she is also employed (the difference between $\$ 589$ and $\$ 427$, divided by two)). Yet those amounts are less than the value of her labor to the market worker. Her caregiving is worth more to the market worker than $\$ 81$ per month or even $\$ 427$ per month.

How do we measure the value of her caregiving to him? At a minimum, the value of her care is the cost of purchasing equivalent care in the market. The caregiver is not quite like the average child-care worker, who earns approximately $\$ 9.28$ per hour, ${ }^{315}$ but is more akin to a nanny, because she gives the child one-on-one attention. A full-time live-out nanny earns about $\$ 705$ per week, ${ }^{316}$ or $\$ 2,820$ per month. Stated another way, the market worker provides the caregiver a benefit of $\$ 427$ per month, but the caregiver provides the market worker a benefit of $\$ 1,410$ per month (half the cost of $\$ 2,820$ ). Of course, her caregiving likely has a higher value to the market worker than is reflected in the cost of a live-out nanny. The $\$ 1,410$ per month does not reflect the added value of having a loving parent care for one's child, and the peace of mind that accompanies knowing that such a person is the caregiver. Nor does it reflect the fact that the non-custodial parent is able to enhance his earnings, acquire seniority, earn credit towards social security benefits, and sock away retirement benefits, while the caregiver is getting no such benefits.

If the couple has a more egalitarian relationship with respect to the allocation of their caregiving and market work, the difference in the value of their exchange may diminish, but it does not disappear. Assume both parents are working full-time and earning an average amount, and the caregiver has custody of the child sixty percent of the time while the market worker has custody of the child forty percent of the time. The caregiver will still provide the market worker with child care worth much more than $\$ 81$ per month. Assuming she cares for the child eight hours more each week than he does, or thirty-two hours more a month, and even

313. This number is derived from a highly simplified and generalized application of an income-shares model to the Oregon Child Support Tables. See Or. Dep't of Justice, Oregon Child Support Bench Book 93-111 (2013), available at http://www.oregonchildsupport.gov/publications/docs/oregon_child_support_ bench_book.pdf.

314. See U.S. Census Bureau, supra note 312, at 459 tbl.703.

315. See Bureau of Labor Statistics, U.S. Dep't of Labor, Occupational Outlook Handbook, Childcare Workers (2012), available at http://www.bls .gov/ooh/Personal-Care-and-Service/Childcare-workers.htm (summarizing facts about child-care workers, including 2010 median pay) .

316. See Nanny Salaries, NAnnies Int'L Inc., http://www.nannies4hire.com/ tips/983-nanny-salaries.htm (citing 2012 INA Nanny Salary and Benefits Survey). 
assuming her labor is worth only what a child-care worker is paid $(\$ 9.28$ per hour), she still provides a service worth $\$ 297$ per month. Moreover, the caregiver will probably not receive the full $\$ 81$ benefit from the father's market work because the father's higher level of caregiving should reduce his child support obligation.

The economics of the situation can certainly change depending upon a myriad of factors. Altering the parties' income and the value of the caregiver's labor can affect the calculations. Sometimes these changes will diminish the disparity in the value of their contributions; sometimes these changes will increase the disparity. The point, however, is not to prejudge the likely effects here. Rather, these sorts of factors should be examined to see whether any unfairness exists, and, if it does, the law should provide a remedy.

4. Any Agreement, Explicit or Implicit, Regarding the Allocation of Market and Home Work and the Sharing of Economic Resources

The final factor that influences an assessment of fairness is whether the parties have agreed to their allocation of labor and resources, and whether they are acting consistently with their agreement. Generally, if the parents have agreed to an arrangement and the parties are acting consistently with it, then there is no unfairness between them. This conclusion is consistent with one of the premises of contract law: the parties' freely negotiated agreement is assumed to be the best outcome for the parties, unless the contract is unconscionable. ${ }^{317}$

In fact, most married couples see the division of labor during their ongoing relationship as fair. A study by Paul Amato and his colleagues found that few married men and only about one-fifth of married women thought the allocation of housework and child care between them was unfair. ${ }^{318}$ Others have reported similar results. ${ }^{319}$ Parties' own assessment of fairness is notable because the couples' arrangement often differs from their expectations at an earlier time in their relationship: "Before the arrival of the first child, couples tend to share the housework fairly equally. But something about a baby encourages the resurgence of traditional gender roles." 320 Research on the views of unmarried cohabiting couples is

317. See Williston \& LoRd, supra note 5, § 18:10.

318. See Амато ет AL., supra note 280, at 154.

319. See Catherine E. Ross \& Marieke Van Willigen, Gender, Parenthood, and Anger, 58 J. Marriage \& Fam. 572, 583 (1996) (“[T] he majority of [married] women, even those objectively overburdened by child care, report that it is a fair arrangement." (citing Mary Clare Lennon \& Sarah Rosenfield, Relative Fairness and the Division of Housework: The Importance of Options, 100 Aм. J. Sociology 506 (1994))). 148.

320. Crittenden, supra note 54, at 25; see also Amato et Al., supra note 280, at 
hard to find, but presumably these couples are similarly content with their division of labor. ${ }^{321}$

Not only do many people characterize their division of labor as fair, but their division of labor usually reflects their preferences. Mothers often prefer not to work outside the home full time. ${ }^{322}$ Lower-income women especially express resentment about their paid employment, in part because their jobs are unfulfilling. They would rather be home with their children, but economic circumstances make that impossible. Similarly, fathers are generally happy working in the market: seventy-two percent of fathers thought a full-time job was the ideal situation for them, ${ }^{323}$ although twelve percent would prefer part-time work and sixteen percent would prefer working solely inside the home. ${ }^{324}$ While men are increasingly finding themselves in a work-family bind, ${ }^{325}$ men do not necessarily want to give up their breadwinning role. ${ }^{326}$

Well, what about those men and women who are unhappy with their division of labor? Does one party's dissatisfaction mean that their agreement is unfair? After all, some situations are suboptimal for one of the parents because he or she would prefer a different arrangement. Consider, for example, a woman who prefers to work full time and have her spouse care for their children, despite the fact that this arrangement would bring the family less income than if the roles were reversed. The woman prefers paid employment because she finds adult interaction rewarding. She also wants her husband to stay at home with their children because she strongly believes that one parent should do so. However, her partner is unwilling to agree to her plan. When she ultimately acquiesces

321. Cf. Sabra L. Katz-Wise et al., Gender-Role Attitudes and Behavior Across the Transition to Parenthood, 46 Developmental Psychol. 18, 27 (2010). But see Maureen Waller, How Do Disadvantaged Parents View Tensions in their Relationships? Insights for Relationship Longevity Among At-Risk Couples, 57 FAm. Rels. 128, 132 (2008) (half of respondents from subset of Fragile Families population mentioned tensions over household and child-care responsibilities during first year of child's life).

322. The recession increased the number of married mothers with minor children who preferred full-time work from seventeen percent to twenty-three percent, and had a similar effect on unmarried women (from twenty-six percent to forty-nine percent). See Pew Research Ctr., Modern Parenthood, supra note 264 , at 13 .

323. Pew Research Ctr., Fewer Mothers Prefer Full-time Work: From 1997 то 2007, at 1 (2007), available at http://www.pewsocialtrends.org/2007/07/ 12 /fewer-mothers-prefer-full-time-work/.

324. See id. at 3.

325. See Jessica Baumgardner, The New Daddy Guilt, Redвoок (Feb. 2, 2013), http://www.redbookmag.com/kids-family/advice/working-dad-stories (discussing challenges men face as they balance work and fatherhood).

326. See Brad Harrington et al., The New Dad: Caring, Committed, and Conflicted 14 (Bos. Coll. Ctr. for Work \& Family, 2011), available at http://www .bc.edu/content/dam/files/centers/cwf/pdf/FH-Study-Web-2.pdf (discussing survey finding that new fathers reportedly rarely took more than two weeks off for paternity leave and ranked "provide financial security" as important factor for being "good father"). 
to an arrangement in which she stays at home with the children and her partner works full time in the market, is that unfair? Is her frustrated preference relevant to an assessment of fairness?

Probably not. While we certainly should have some sympathy for this woman, she probably deserves no more sympathy than any other person who finds their choices constrained by life's circumstances. We may fault her for inadequately vetting her partner before conception, but perhaps she did so and her partner later changed his formerly egalitarian orientation. Or, perhaps, her own views about the importance of market work only crystalized once she had children. Going forward, she is not without options. No one can stop her from taking a full-time job and enrolling her children in day care, not even her partner. Nor can anyone stop her from leaving the relationship and requesting visitation instead of custody. Of course, neither of these options is a great solution, nor even a good solution. Nonetheless, her decision to stay home with her children-if freely made-is not the sort of decision that the law should be concerned about just because it does not reflect her ideal preferences. Most people's lives have been influenced and constrained by reality. ${ }^{327}$ The law should only be concerned if her partner does not fairly compensate her for that caregiving.

Not everyone would agree. Reporter Ann Crittenden would argue, for example, that women do not bargain from a point of equality after the first child arrives. At that point, the woman's bargaining power decreases because she is less likely to leave the relationship. "If he refuses to clean up after dinner, what is she going to do? Threaten to leave with the baby? Not likely." 328 While a woman has less bargaining power the more she becomes dependent upon her partner for money, ${ }^{329}$ similar pressures exist for the market worker after the child's birth. A market worker may have the money to leave the relationship, but he may remain in a relationship because he fears losing contact with his child, or losing the other parent's ability to caregive (especially if maintaining two households would require her to work more in the labor market). To put it another way, if she refuses to clean up after dinner, what is he going to do? The child probably constrains both parties' ability to bargain about their respective roles, but it certainly does not eliminate their ability to bargain, or even to leave. In fact, women with children initiate more divorces than men with children. ${ }^{330}$

327. The fairness of their arrangement is not affected by the economic rationality of the decision. The same conclusion could be drawn even if she would have made more money than her spouse.

328. See Crittenden, supra note 54, at 113.

329. See id.

330. See Margaret F. Brinig \& Douglas W. Allen, "These Boots Are Made for Walking”: Why Most Divorce Filers Are Women, 2 Amer. L. \& Econ. Rev. 126, 126-27 (2000). 
The parties' agreement is an important component of assessing fairness because it also provides a standard against which to measure the adequacy of the parties' sharing behavior. Breaches of an agreement are generally an indication of unfairness. Breaches can occur during the romantic relationship or at its conclusion. A breach is essentially when one parent alone decides to change the arrangement so that it solely or predominantly benefits him or her. The parents can certainly change their agreements as their circumstances change, but the beauty of an agreement is that both people must decide together what is a fair arrangement for the new normal.

Assuming the parties' have an agreement, the agreement by itself should not be the sole measure of whether unfairness exists. Otherwise, the adjudication would be akin to a contract-based claim. As Professor Ira Ellman explained in his important article, A Theory of Alimony, certain limits exist to a contract-based approach to alimony. Similar limits exist to a contract-based approach to caregiver payments. While some of his concerns might be obviated by a requirement that a written agreement exist, ${ }^{331}$ others remain. For example, a contractual approach necessitates an assessment of who was at fault for breaching the agreement, ${ }^{332}$ and assessing fault is now passé in the divorce context in many locations. Also, a contractual approach suggests that a market worker should be entitled to a remedy if the caregiver ceases or reduces her caregiving in a way that is contrary to their agreement, and that seems misguided. A purely contractual remedy would also work only for unmarried caregivers, ${ }^{333}$ as spouses cannot enforce a contract about compensation for household labor under existing family law. ${ }^{334}$ If the agreement were an important component of any fairness analysis, instead of an enforceable contract, then the law could treat all parents similarly. Although all parents could also be treated similarly if all contracts were enforceable, this approach is inferior because the level of compensation has sufficient public importance that the parties' determination should not be definitive. Family circumstances can change overtime, including the parents' romantic and legal relationship to each other, and a contract can become unfair.

Although an agreement is an important component of assessing fairness, making the parties' agreement relevant to a legal action is not without its downsides. If the agreement was oral, there may be disagreement about its existence, its terms, and its subsequent modification, and assessing credibility in this context might be difficult and time consuming. For this reason, judges may limit relevant agreements to those that are written.

331. Among other things, he argues that the parties' understanding is rarely known and too vague if known. See Ellman, supra note 125, at 20.

332. A remedy requires a material breach of the agreement even if the dissolution will cause her disproportionate hardship. See id. at 19.

333. See id. at 11, 23.

334. For a discussion of the unenforceability of household labor compensation contracts under current law, see supra notes 8-9 and accompanying text. 
Another concern is whether parents might start "bean counting" during the relationship if an agreement is an important component of the fairness assessment. That is, will parents undertake elaborate record keeping to track who is doing what and their sharing behavior? Such recordkeeping might be burdensome and foster distrust. This concern should not be discounted, but its importance should not be overstated either. Certainly a party will need to prove who does what type of work, in what proportion, and for what type of remuneration, in order to prevail in court on a claim for disproportionate and unfair caregiving. However, bean counting is triggered by both the availability of a remedy and a party's feeling that the arrangement has become unfair. It seems misguided for society to ignore the potential injustice just because addressing it requires the aggrieved party to document it. Moreover, bean counting is not something to be feared. Recording actual patterns of behavior can help the parties resolve their dispute without court intervention. A recording helps parents visualize what is actually happening, thereby allowing them to better understand it and change it.

Finally, courts will eventually need to resolve many subsidiary issues if agreements matter to an assessment of unfairness, and this takes time and energy. In the absence of an actual agreement, should the law infer an agreement for certain categories of couples? If so, what would that agreement look like? For example, should a court presume that the parties agreed to the existing allocation of labor and an equal sharing of income in any marital or marital-like relationship until the child reaches eighteen, even after the romantic relationship ends, absent a written contract suggesting otherwise? Should a court presume that a non-cohabiting, unmarried couple did not agree to an equal sharing of income as compensation for disproportionate caregiving, absent a written contract suggesting otherwise? While these questions are important, they do not detract from a court's ability to use the parties' actual agreement to inform a determination of fairness when such an agreement exists. Moreover, some of these questions should be answered in the context of determining the appropriate alimony theory to apply to the situation, as discussed below.

In the end, the four factors set forth above should help a decisionmaker decide whether the disproportionate allocation of caregiving is unfair. The next question is, "so what?" Judges will then need to canvas the available theoretical approaches to compensation and choose the most appropriate one in light of the parties' circumstances.

\section{Theoretical Tools That Will Help Determine the Remedy}

The hardest part of the court's task will be to craft the remedy for disproportionate and unfair caregiving in a particular case. ${ }^{335}$ The judge

335. The caregiver should have access to the remedy when she no longer cohabits with the other parent, or at any time if the couple never cohabited. This approach to the timing of the remedy best comports with family law doctrine. It 
should award an amount to compensate the caregiver as opposed to remedy her needs, for reasons explained below. The judge should draw upon the existing theoretical work on alimony, as appropriate, to determine fair compensation. The most compelling theory will depend upon case-specific factors, such as the nature of the couple's broader relationship, the contours of property and alimony law in that jurisdiction, and the difficulty of the fact-finding task at the time of the adjudication. The court must coordinate the new remedy with the existing remedies, such as alimony and property division. ${ }^{336}$ The new caregiver remedy must not harm divorcing caregivers by lowering the total amount of money they receive upon divorce, nor should it subject a divorcing obligor to pay for something twice.

Although courts should draw upon the existing theoretical work on alimony to fashion a remedy, two caveats are necessary. First, judges must not allow existing alimony theory to stymie their ingenuity. Alimony and its theoretical underpinnings are tied to the marital context. Equating caregiver payments to alimony, or embedding caregiver payments within alimony for married couples, may import a lot of unnecessary and inappropriate doctrinal baggage, such as a requirement of "need," 337 or the award's termination upon remarriage of the recipient. ${ }^{338}$ It may also in-

will also make it easier for a court to coordinate this remedy with other remedies, and to ensure that a party is not receiving a double recovery. The caregiver payment fills the gaps for couples that are eligible for alimony and property division, and a court needs to consider all three remedies together. In addition, limiting the remedy's availability to the end of the cohabiting relationship allows a claimant to reassess fairness in light of the entire relationship.

Perhaps the biggest disadvantage of this approach is that parents may be encouraged to end their cohabiting relationships in order to access the remedy. See generally Carl E. Schneider, Rethinking Alimony: Marital Decisions and Moral Discourse, 1991 BYU L. Rev. 197. There are several responses. First, not all parents should cohabit. Some parents should not live together or should separate, and it would be beneficial if the remedy incentivized this behavior for that group. See Ellman, supra note 125 , at 56 . Second, for most couples with a healthy relationship, one remedy alone will probably not affect the couple's willingness to cohabit or marry. Third, the remedy will incentivize the acts of the likely obligor just as much as it incentivizes the acts of the likely recipient, and it is anyone's guess how these dynamics will play out for a particular couple. If anything, the remedy may encourage cohabitation because the obligor has more to gain from successful cohabitation than the recipient has to lose from unsuccessful cohabitation. After all, the caregiver's remedy does not disappear upon cohabitation, but is only delayed until cohabitation ceases.

336. Courts already coordinate alimony and property awards. See, e.g., June R. Carbone \& Margaret F. Brinig, Rethinking Marriage: Feminist Ideology, Economic Change, and Divorce Reform, 65 Tul. L. Rev. 953, 999 \& n.202 (1991); Laura Morgan, "Double Dipping": A Good Theory Gone Bad, 25 J. Am. Acad. Matrimonial L. 133 (2012).

337. See Unif. Marriage \& Divorce Act $§ 308$ (amended 1973), 9A U.L.A. 446 (1998).

338. See Carbone, supra note 1, at 70-71 (explaining remarriage would affect expectancy measure but not unjust enrichment measure based upon ideas of mitigation of damages); $c f$. Perry, supra note 9, at 29 (noting that when alimony is 
hibit the development of totally new approaches to remedying this type of injustice.

Second, the focus here on alimony as a source of inspiration is not meant to suggest that the law of property should be ignored. Rather, alimony is discussed here because of the historic differentiation between property division and alimony, and because of the current legal gaps for remedying unfair, non-marital and post-marital caregiving. Professor Krauskopf explained that divorce law differentiates between assets and obligations on the one hand, and personal gains and losses on the other hand. ${ }^{339}$ The theory that justifies splitting a couple's assets and obligations upon divorce is the idea that the marriage is a partnership to which both parties contribute time and effort for the benefit of the entire family and from which both expect to share any gains. ${ }^{340}$ In contrast, alimony is awarded to "fairly share gains and losses in personal earning capacity" 341 in order to prevent unjust enrichment. ${ }^{342}$ Admittedly, Professor Krauskopf's explanation is a little dated today, ${ }^{343}$ but it is still useful because it emphasizes that marriage involves an expectation that the parties will share the accumulated property. Co-parenthood, without more, does not have that same social meaning, although sometimes it might for a particular couple. Since the law's present gaps mostly affect unmarried and divorced caregivers, and since these caregivers are much less likely than married caregivers to have a broader economic partnership or expectations about sharing all of their property, property doctrine seems less helpful. In contrast, alimony doctrine, which includes compensation for unjust enrichment, seems useful for a wide array of caregivers.

Alimony is also a good analogy for caregiver payments for another reason. Any new remedy needs to draw from a market worker's future income if it is to be meaningful. A property award typically relies upon property in existence at the time of the award, whereas an alimony award typically relies upon the obligor's future income. Most couples have too little property at the time of breakup to compensate for both past and future caregiving. ${ }^{344}$ As law professor Cynthia Starnes starkly noted,

conceived of as compensation for work done, it makes no sense to terminate it upon remarriage or cohabitation).

339. See Krauskopf, supra note 88 , at $257-58$.

340. See id. at 258-59.

341. Id. at 266. There are other purposes, including compensation for loss of marriage prospects and for physical or mental injury. See id. at 266-67.

342. See id. at 260.

343. The lines demarcating alimony and property awards have become blurred over the years. Most courts draw on some of the same considerations to award both property and alimony according to "their own notions of fairness." See Ellman, supra note 125, at 12.

344. See Starnes, supra note 93, at 211 (noting that average divorcing couple only owns property worth approximately $\$ 25,000$ when home equity is excluded). 
“[n] othing from [n] othing [1] eaves [n] othing." 345 Since the breadwinner will typically have a lifetime of earnings, that stream of income should be accessible to compensate the caregiver.

Although alimony is the better analogy for the new caregiver payment, nothing in this article is meant to prohibit a court from awarding property to compensate caregiving efforts, especially when courts already do so. A property award might even be an appropriate option to compensate future caregiving if a moocher has tremendous assets but no anticipated future income. It might also be appropriate when the parties agreed to share property as fair compensation for caregiving. The point is not to foreclose further legal developments or to limit courts' discretion, but rather to point out those tools that are most likely to help courts remedy the situations that are most in need of a remedy.

\section{Need Versus Compensation}

While meeting economic "need" and affording "compensation" are both goals of alimony, and while both can justify an award to a parent for disproportionate and unfair caregiving, compensation is preferable to need as an objective. After all, not all caregivers are needy. A compensatory rationale is broader than a need rationale.

A compensatory rationale is also a preferable theory even for needy caregivers. First, a caregiver's financial need may be unrelated to her caregiving. The caregiver may have needed public assistance regardless of whether she ever had a child. If so, there is scant reason that her coparent should be responsible for her needs as opposed to the public, especially if they are unmarried. While caregiving may exacerbate the caregiver's financial need, it would be a very complicated task to try to figure out how much her caregiving contributed to her need. The slipperiness of the need concept will also contribute to the challenges associated with a determination of need. ${ }^{346}$

Second, even if caregiving causes the caregiver's dependency or need, most caregivers would probably prefer to receive compensation for a benefit conferred rather than support for their dependency, assuming the amounts were similar. Appropriate messaging is one of the reasons that the authors of the ALI Principles, discussed above, re-characterized the purpose of alimony from satisfying needs to affording compensation: it "transforms the claimant's petition from a plea for help to a claim of entitlement." 347

Third, a compensatory rationale would probably attract less political opposition than a need rationale in light of the fact that the caregiver

345. Id. at 209 (quoting Billy Preston, Nothing from Nothing, on Nothing FROM Nothing (A\&M Records 1974)). at 4 .

346. See Principles $§ 5.05$ reporter's note, cmts. a \& f; Ellman, supra note 125,

347. Principles $§ 5.02 \mathrm{cmt}$. a. 
remedy will extend to unwed parents. Those who want to protect the institution of marriage may think that requiring an income transfer for need blurs the line between marriage and unwed co-parenthood too much. One of marriage's hallmarks is that a spouse is required to support his or her partner when that partner is in need. Compensation, however, is a concept that is not tied to marriage. It currently justifies payments between all sorts of people, including strangers. In fact, the law regulating business partnerships embodies a compensatory concept, akin to restitution. A partner who contributed a disproportionate share of labor to the business partnership may be entitled to compensation after the partnership ends; ${ }^{348}$ it is an exception to the rule that partners have no ongoing obligations to each other after liquidation. ${ }^{349}$

A study by Ira Ellman and Stanford Braver arguably challenges the assumption that a compensatory rationale will have more popular appeal then a need rationale. Their study indicated that people would rather see the law award alimony for current caregiving than as compensation for the loss in earning potential associated with past caregiving. ${ }^{350}$ In their study, subjects preferred to award alimony to a woman with adult children slightly more than a woman who was childless (forty-eight percent to fortyfive percent), but subjects were most willing to award alimony to a woman with young children (fifty-eight percent received alimony). ${ }^{351}$ The authors concluded that the subjects "care most of all about the claimant's responsibility as primary caretaker of the couple's minor children, to some extent but noticeably less about the partner's marital status and their relational duration, and very little at all about the claimant's history of having cared for the couple's now-grown children." 352 In fact, their survey may have even undercounted the full number of respondents who would favor an award for current caregiving because the respondents were told that the caregiver would receive child support; the respondents may have assumed that the child support was also meant for the caregiver. ${ }^{353}$

The study's results are certainly open to interpretation and may suggest little about the political feasibility of a compensatory rationale. After

348. See Ellman, supra note 125 , at 37.

349. See id. at 35.

350. See Ellman \& Braver, supra note 31, at 239-40.

351. See id. at 224 .

352. Id. at 239-40.

353. Survey respondents may have assumed that caregivers already received something equivalent to alimony (whether for need or compensation) through child support, and this assumption may have repressed their willingness to award additional amounts. Respondents were told that child support was being awarded and they may have inferred from the numbers that the child support award was also to benefit the caregiver. In fact, amounts were higher than what the child support guidelines required and had built in premiums for marriage and maritallike relationships, at least when the noncustodial parent had sufficient resources. See id. at 226-27. Survey respondents did award lower amounts of alimony for married couples when the child support amount was higher, although the effect was less evident for unmarried couples. See id. at 227. 
all, almost half the respondents did want to award alimony to a woman with adult children for her past caregiving. If anything, the results may suggest that the survey respondents were expressing a preference about the timing of the remedy more than rejecting a "compensatory rationale" in favor of a "need rationale." Respondents might have shown great support for a compensatory rationale if the award were given to the caregiver as she did the work. Caregiver compensation, as proposed in this article, would be available for many unmarried and all divorced caregivers as they did the caregiving work.

The discussion now turns to compensation, because a compensatory rationale often seems superior for the reasons specified above.

\section{The Possible Theories Behind the Remedy If the Goal Is Compensation}

The decision to compensate a caregiver instead of provide for her need does not end a judge's task. What does it mean to compensate a caregiver? No single answer exists in the context of alimony, although scholars have successfully identified several theoretical approaches. Professor Cynthia Starnes has catalogued well the three basic approaches, ${ }^{354}$ noting that they correspond loosely to expectation, reliance, and restitution damages under contract law. ${ }^{355}$ The usefulness of these compensatory theories differs depending upon the particular caregiving fact pattern. As will become obvious, all three theories make some sense, some of the time, for some disproportionate and unfair caregiving. The inability to find one all-encompassing theory makes it essential that decision makers have access to all of the theories and match the best theory to the circumstances.

\section{a. Gain Theory}

Gain theory is the first possible approach to compensation. In the marriage context, this theory means that alimony should reflect the gain that the claimant would have obtained had she remained married. The amount would include a share of her husband's post-divorce income to the extent that her efforts during the marriage contributed to his ability to earn this future income. Gain theorists recommend a remedy that is an amount either to "equalize income or household standards-of-living or . . . [that reflects] a percentage of income disparity based on the duration of the marriage." 356

Gain theory makes a lot of sense for parents who were in a marital or marital-like relationship and are seeking a remedy at the end of that rela-

354. See Starnes, supra note 20, at 278-79.

355. See id. at 278. Although the contract law analogy is helpful, at least one of the theories-loss theory-is also justified on functional grounds unrelated to contract concepts. See Ellman, supra note 125 (arguing that contract and partnership concepts are futile and proposing functional understanding of alimony).

356. Starnes, supra note 20, at 290. 
tionship. The remedy is appropriate because the parties' marriage involved an implicit agreement that both would contribute to maximize the couple's collective well-being and both would share in the bounty, including the couple's economic prosperity. As mentioned, this theory already guides courts and legislatures in their approach to property division on divorce. Cynthia Starnes explains that this theory justifies awarding the caregiver a share of the market worker's enhanced earning capacity since it is the "spouses' combined efforts" that created it, and the market worker will continue to enjoy it. ${ }^{357}$ Professor Starnes herself recommends this remedy for married couples with children based on the parenting enterprise. ${ }^{358}$

While gain theory is an attractive approach to remedy the effects of marital caregiving for divorcing parents (and perhaps also to remedy the effects of post-marital caregiving, see below), it seems like the wrong approach for some other parents, such as parents who only had a short dating relationship. In part, the measure helps compensate for a married individual's foregone opportunity to marry another person who would have an obligation of support, ${ }^{359}$ but an unmarried caregiver does not lose that opportunity (although the child may diminish it). Moreover, gain theory rests on the idea that the caregiver had legitimate expectations to share the market worker's income over the long term. Marriage involves a broad agreement between the parties. Professor Katharine Baker once noted: "Marriage involves an agreement to share profits and liabilities in all enterprises forever." ${ }^{600}$ Nothing like that necessarily exists in a parenting relationship created by a one-night stand. Neither the caregiver nor the market worker is likely to expect long-term income sharing without a broader partnership akin to marriage. Marriage is the relationship that gives rise to such expectations, although certain marriage-like arrangements can do so also. If gain theory were always used to remedy disproportionate and unfair caregiving, regardless of the parties' broader relationship, then the remedy would turn all parental relationships into something that felt like marriage, contrary to the parties' expectations.

Relatedly, gain theory seems inappropriate when the parents lack a marital-like relationship because the market worker's prosperity is less likely to be attributable to the caregiver's efforts. A market worker's enhanced earning capacity is likely attributable to his spouse's caregiving, but also to her emotional support, companionship, general housekeeping, and perhaps activities like the hosting of business dinners. Gain theory seems to make the most sense when the parties are married or in a maritallike relationship, because the couple probably had a broad partnership that involved these other types of contributions too.

357. Starnes, supra note 55, at 1543-44. Starnes recommends, "[s]uch a husband should therefore buy out the interest of his wife at divorce." Id. at 1544 .

358. See Starnes, supra note 93, at 201.

359. See Brinig \& Carbone, supra note 1, at 878.

360. Baker, supra note 82, at 1198 . 
Gain theory also seems the more appropriate for caregiving in marital relationships because the marital caregiver is more likely than other caregivers to share the market worker's liabilities at break-up. It is questionable whether the caregiver should get to share in the market worker's gains if the caregiver has no potential exposure for any of the market worker's debts.

Finally, gain theory also has limited appeal for unmarried couples in some specific contexts. For example, it would be difficult to apply during an ongoing romantic (but non-cohabiting) relationship because the caregiver's expectations of sharing in the gain may not have been conclusively frustrated, but only delayed.

Gain theory could also be used to compensate a caregiver for her post-divorce caregiving by awarding her the market worker's enhanced earning capacity that is attributable, at least in part, to her efforts. This would rest on the idea that a marital couple expected to share the market worker's future income in exchange for caregiving, that this expectation extended to the child's entire minority, and that the caregiver's post-divorce efforts will help the market worker enhance his earnings. On the other hand, gain theory may be an unappealing measure for post-divorce caregiving. After all, the caregiver can now remarry, and her post-divorce caregiving may contribute much less to the market worker's enhanced earning capacity than the combination of caregiving, homemaking, companionship, and emotional support that she provided during the marriage. Additionally, after the marriage ends, the caregiver has no responsibility for the market worker's financial failures. The market worker might also question whether the parties expected to share his postdivorce enhanced earning capacity in a world of prevalent divorce shaped by a "clean break" ideology.

Arguably, gain theory is inappropriate when the caregiver is to blame for the romantic relationship's end. Imagine a married caregiver who walks away from the relationship and the sharing that the market worker was willing to do in order to be with her new boyfriend. To some, it will seem unjust to the market worker to award the caregiver the amount she would have received had she stayed in their relationship. Even assuming gain theory should be used as a basis for remedying her disproportionate and unfair marital caregiving (because the caregiving labor occurred before her blameworthy behavior caused the breakup of the marital relationship), it certainly seems problematic to give the adulterer a share of the other parent's enhanced earning capacity accrued after the relationship ends, even if her post-marital caregiving contributes to his enhanced earning capacity. In fact, in some states, adultery and desertion could disqualify the caregiver from receiving alimony altogether, ${ }^{361}$ and in others it

361. Twenty-two statutes consider fault in determining support. See Carbone, supra note 1, at 55 (citing Principles). 
could affect the application of a gain theory measure. ${ }^{362}$ If the parents never married, the philandering caregiver would not technically be an adulterer or deserter. Although no legal concept of fault is applicable, the caregiver's behavior is still arguably condemnable. Without a clear definition of fault in the context of the unmarried co-parenting relationship, gain theory may always be inappropriate, or at least inappropriate for remedying disproportionate and unfair caregiving provided after the relationship's end. On the other hand, if a no-fault state deems fault irrelevant to alimony determinations, ${ }^{363}$ then gain theory should be available both to married and unmarried couples regardless of fault (although other reasons might justify distinguishing between divorcing and unmarried couples for purposes of the theory's availability).

\section{b. Loss Theory}

Loss theory is another approach to alimony. Under this theory, alimony compensates the claimant for her losses attributable to her marriage. Historically, the "most important loss was the opportunity to have married another" and receive support from that person. ${ }^{364}$ The availability of no-fault divorce makes the expectation of life-long marriage and support debatable, ${ }^{365}$ so losses are now identified as the lost economic opportunities from caregiving during the marriage. The remedy seeks to "put the injured spouse 'in as good a position as he [or she] would have been in had the [marriage] not [occurred]." "366 The caregiver's losses are shared because they will continue after divorce, and are not offset by the sharing that occurred during marital cohabitation. The measure of the loss is generally the claimant's lost earning capacity (i.e., the difference between the claimant's current earning capacity and that which she would have had if she had never married), ${ }^{367}$ so long as her efforts resulted in a financial gain to her spouse. ${ }^{368}$

Loss theory rests on the idea that the caregiving spouse made her decision to caregive with the expectation that her relationship and the sharing behavior would continue, at least long enough to get "a return" on her investment in the relationship. ${ }^{369}$ When the romantic relationship

362. See Carbone, supra note 1, at 44, 53 (explaining that expectation measure embodied in gain theory has historically been tied to fault, and measure may make most sense only for innocent recipients).

363. See generally Principles ch. 1 intro., topic 2, pt. III (giving reasons to exclude consideration of fault); see also Carbone, supra note 1, at 72-73 (describing why determination of who "breached" may not be relevant); Ellman, supra note 125 , at 66 (arguing fault is not relevant under his proposal).

364. Brinig \& Carbone, supra note 1 , at 873.

365. See Rogerson, supra note 230 , at 72.

366. Starnes, supra note 20, at 284 (footnote omitted).

367. See id. (citing Ellman, supra note 125, at 49).

368. See Ellman, supra note 125, at 67.

369. See Brinig \& Carbone, supra note 1, at 894; see also Principles $§ 5.05 \mathrm{cmt}$. a. 
ends, the caregiver should be compensated with an amount that would put her back in the position that she would have been in had she never married.

Loss theory has also been justified functionally: loss theory "encourage[s] socially beneficial sharing behavior in marriage." 370 Proponents claim that it allows the couple to arrange the allocation of market work and caregiving between them according to their preferences because the caregiver's investment is protected. ${ }^{371}$ Most couples will probably choose to have the higher-income individual engage in more of the paid work because that arrangement provides the couple with the most economic resources. ${ }^{372}$

The loss measure has some distinct advantages over gain theory. Fault, or any other reason for a break up, appears irrelevant to an award predicated on loss theory, unlike with an expectation measure. ${ }^{373}$ Even a blameworthy caregiver deserves compensation for her past caregiving to the extent that it causes her enduring losses and the other parent benefited from her work. Fault, however, is probably not completely irrelevant. For example, courts would likely disallow this remedy for a claimant who wrongfully abducted the children and thereafter claimed that she was owed compensation for her lost earning capacity. Perhaps some types of fault are relevant because the blameworthy behavior undermines the functional rationale for the measure; the behavior makes impossible an agreement about the best allocation of market and caregiving work.

Just like the expectation measure, the loss measure seems consistent with the norms of some co-parenting relationships, but not others. Many couples enter the co-parenting relationship expecting to share the breadwinner's income, although unmarried caregivers may have a more modest expectation about sharing than married couples. The unmarried caregiver's expectation, however, may still be significant enough to cause her harm when the sharing stops. Other couples have no expectation of sharing anything, and, therefore, the measure seems misplaced for those couples. To the extent that the measure rests on a functional rationale (to encourage the best allocation of market and home work for the couple), ${ }^{374}$ then a loss measure seems appropriate for parents that make decisions together about the allocation of caregiving work and the sharing of resources, regardless of their marital and romantic status.

Even if loss theory seems applicable, it is not always the best compensatory measure. It can pose real challenges for a claimant in certain situations. Loss theory-to the extent that it addresses opportunity costs-

370. Ellman, supra note 125, at 12.

371. See, e.g., id. at 50-51.

372. See id. at $46-47$.

373. See id. at 66; Brinig \& Carbone, supra note 1, at 879, 895-96, 901-02.

374 . For a discussion of a functional rationale where spouses allocate market work depending on income capacity, see supra notes 356-59 and accompanying text. 
requires an assessment of losses actually experienced that were not offset by past sharing in a partner's prosperity. Trying to assess whether a party has received the "full value during the marriage [or relationship] is impossible," 375 and determining precisely how much value a caregiver received may be even more difficult for unmarried couples that share. In addition, determining the caregiver's actual losses attributable to caregiving can also be problematic. The caregiver's current earning capacity may reflect factors like her ability and ambition, rather than factors related to her caregiving, at least in part. ${ }^{376}$ In addition, calculating actual earning capacity loss can be "costly to the extent it requires expert evidence." 377 Loss theory also undercompensates those who are "market challenged," i.e., people with low education or ability. These individuals may have little, if any, real income loss from caregiving, although they provide a useful service to the other parent. ${ }^{378}$

The ALI Principles use loss theory as a basis for spousal compensation, but they do not try to compensate opportunity costs in a strict fashion. Among other adjustments, the ALI Principles get around some of these valuation problems with a unique formula for calculating loss, but this solution does not work so well for unmarried parents. Judges are supposed to subtract the caregiver's current income from her partner's income and then multiply the difference by a number that represents the number of years of caregiving. Her partner's income supposedly reflects the level of income that she could have earned, and therefore likely lost, because people tend to marry someone from the same socio-economic background. Unmarried parents, however, are not married to each other, and it may be wrong to assume that they come from the same socio-economic background, at least without particular evidence establishing that fact.

Professor Starnes reports that the difficulties of calculating loss have led some proponents of loss theory to fall back on the remedies proposed by gain theorists. ${ }^{379}$ This solution seems particularly inappropriate if the parents lacked a broader partnership like marriage or lacked an expectation of sharing economic gains, or if the measure is applied to post-relationship caregiving in a jurisdiction where fault is relevant and the claimant's wrongful behavior caused the relationship's end.

\section{c. Contribution Theory}

Some courts rely on contribution theory, also known as "unjust enrichment," in order to award a spouse the amount he or she has contributed to the other spouse's prosperity. The remedy tries to address the

375. Ellman, supra note 125 , at 55 .

376. See Schneider, supra note 335, at 230.

377. See Rogerson, supra note 230 , at 84 .

378. See Singer, supra note 6 , at 2443.

379. See Starnes, supra note 20, at 285. 
situation in which one parent unjustly benefits at the expense of another. The focus is on the value of what the non-market spouse gave to the market spouse, measured either by the caregiver's actual uncompensated monetary and nonmonetary contributions, or by the effect that these contributions had on the market worker's earnings. This measure is typically used when one spouse contributes financially to the other spouse's education, but then receives none of the benefits from the spouse's degree because the parties divorce shortly after the degree is conferred. ${ }^{380}$ The claim disappears if the contribution conferred was conferred as a gift.

The rationale behind contribution theory makes sense for all parents regardless of marital status. It does not require that a party have any expectation about long-term sharing or an agreement to engage in any sharing at all; nor does it require a broader relationship that typically gives rise to expectations of sharing. A caregiver need not suffer a measurable loss to her income from caregiving in order to recover. Contribution theory is generally unaffected by whether the claimant is at fault. ${ }^{381}$

Contribution theory is not a panacea, however. Contribution theory will not always be the best measure to remedy disproportionate and unfair caregiving because it sometimes does not comport with the parties' legitimate expectations. Caregivers in a long-term committed relationship would be disappointed if they only received reimbursement for their efforts when they legitimately expected to share in the fruits of their partners' prosperity. ${ }^{382}$ Also, valuing the contribution for purposes of reimbursement is fraught with difficulty. The market typically values caregiving at a very low rate. ${ }^{383}$ If a court only uses the actual market value of the care to determine the dollar value of the remedy, then higherincome individuals will be discouraged from caregiving. ${ }^{384}$ Perhaps a better measure of the care's value is the true cost to the caregiver to provide the care; but that measure then requires one to calculate lost opportunities, with all of its difficulties.

Measuring the effect of the caregiving on the market worker's earnings also poses problems. Earnings may not capture the true value of the service provided because parental caregiving confers unique benefits that defy monetization. The market worker receives important nonfinancial benefits, such as having his children "raised in accordance" with his "preference[ ] for direct parental care." 385 The market worker also gets to structure his time with fewer constraints, and this flexibility can produce a sense of personal freedom in addition to the job-related financial benefits

380. See, e.g., Mahoney v. Mahoney, 453 A.2d 527, 533-34 (N.J. 1982).

381. See Carbone, supra note 1, at 44 ("[P] ortions of the divorce award, most notably those that approximate restitution principles, are independent of the reasons for the breakup of the marriage.").

382. See Starnes, supra note 20, at 286.

383. See Baker, supra note 222, at 337.

384. See Ellman, supra note 125 , at 72.

385. Carbone, supra note 1, at 68. 
(from longer and more uninterrupted work hours). While some scholars and judges have called upon courts to capture these types of gains, ${ }^{386}$ courts generally do not do so because it is a complicated task, ${ }^{387}$ so they instead focus on what was given. ${ }^{388}$

Some scholars dismiss unjust enrichment as a remedy for disproportionate caregiving for other reasons. Professor Starnes, for example, dislikes this compensatory remedy, in part, because it would require courts to "'total up and compare [the spouses'] individual contributions'" instead of working off a presumption that both contribute equally to the marriage. ${ }^{389}$ This concern has merit for marital couples (and Professor Starnes focuses on those couples), but it has no merit for non-marital couples, because no presumption is currently operating or should necessarily operate for them. Totaling up contributions is arguably a better approach than no remedy at all for unmarried couples, which is the position at present. Moreover, courts could develop tools to minimize the accounting involved, such as a rebuttable presumption that the caregiver's contribution is as valuable as the market worker's earnings during the relevant period, or that members of a cohabiting couple shared the breadwinner's income fairly between themselves. The real question is whether such presumptions are warranted at all given the value of the activities and the absence of a broader economic partnership between the parents.

Professor Ira Ellman dislikes the restitution analogy for the marital context because any claim for excessive contributions requires the court to know a typical spouse's contribution, and such a yardstick does not exist. ${ }^{390}$ Again, however, courts and legislatures could create a yardstick in the caregiver compensation context: the default rule could be one of equal caregiving effort during the parenting enterprise. Whether any disproportionate caregiving rose to the level of "unfair" would be the next question, and the answer would depend upon the factors identified above. As to whether their sharing behavior was adequate, the law could presume that a caregiver is entitled to the greater of either 1) half of the amount of the market worker's income attributable to the time during which the caregiver did excessive work or 2) the market value of the caregiving. That measure would be the yardstick. If a caregiver did seventy percent of

386. See Robert Kirkman Collins, The Theory of Marital Residuals: Applying an Income Adjustment Calculus to the Enigma of Alimony, 24 Harv. Women's L.J. 23, 49-50 (2001); Rogerson, supra note 230, at 86 (mentioning Canadian case law); Singer, supra note 6 , at 2445-47, 2454-55 (proposing post-marital income sharing).

387. Cf. Witmer \& Warner, supra note 14, $\$ 9.4$ (noting practitioner's difficulty putting on evidence for reimbursement alimony).

388. See Starnes, supra note 20, at 286-87; see also Cox v. Cox, 762 A.2d 1040, 1046 (N.J. Super. Ct. App. Div. 2000).

389. Starnes, supra note 20, at 287 (citing June Carbone, Economics, Feminism, and the Reinvention of Alimony: A Reply to Ira Ellman, 43 Vand. L. Rev. 1463, 1483 n.87 (1990)).

390. See Ellman, supra note 125 , at 39. 
the caregiving, then the market worker should owe the caregiver half of his income earned during the twenty percent of the caregiver's time that covered his responsibility or an hourly wage based on the hours of care she provided, whichever is greater. If she received less than that amount from him, then she should be compensated for her disproportionate and unfair caregiving, absent an agreement or other facts that make their arrangement fair.

The discussion above illustrates the difficulty of choosing one measure to address all situations. ${ }^{391}$ Courts need access to all of the measures in order to do justice in the cases before them. It is not science, but arriving at a remedy is not unprincipled either.

\section{Disadvantages to the Proposal: The Fear and the Sneer}

Giving all caregivers access to justice would be the main benefit of a new obligation to give care or share. In addition, a new obligation to give care or share would send a stronger normative message than any message that may currently exist from divorce remedies for marital caregiving (i.e., the message would be to give care or share). Do these benefits outweigh the potential disadvantages? Apart from process concerns related to judicial discretion, do other potential disadvantages outweigh the benefits from such a proposal?

One potential disadvantage is that an award for disproportionate and unfair caregiving may encourage caregivers to perform an economically inefficient amount of caregiving, that is, to become freeloaders themselves by engaging in excessive caregiving. The temptation may be especially great for caregivers who could get a caregiver payment as great or greater than what they could earn in the market.

Assuming for purposes of this analysis that caregiving can be "excessive," this risk seems relatively minor, especially in light of the systemic freeloading done presently by market workers. After all, the caregiver payment may have little or no effect on the absolute level of caregiving performed by caregivers because people partake in paid labor for lots of reasons-including self-esteem, economic need, retirement benefits, and a Protestant work ethic. In addition, excessive caregiving would undermine a claim that the level of sharing is unfair. A court would probably consider any agreement the parties had about the appropriate level of caregiving, or, absent an agreement, use other tools to assess the argument's merit, such as the work requirements found in Temporary Assis-

391. This discussion has avoided arguments that challenge the assumptions of the existing alimony theories, such as the fact that the parties' expectations guide a decision about the appropriate theory. Arguably, the parties' expectations should be irrelevant since the law heretofore has shaped those expectations, perhaps in an unfair way. Advocates, of course, could make these types of arguments when asking for a particular remedy, and it would be up to judges to determine what seems "just" given the circumstances. 
tance to Needy Families (TANF) ${ }^{392}$ or demographic data that specifies the average amount of parental caregiving children receive in a particular socio-economic class. Courts could also look to information about the availability of safe and affordable child care in an area. In short, courts have ways to determine if caregivers are freeloading, assuming that the concept of excessive caregiving does not violate public policy.

Second, critics might claim that the remedy is unfair to market workers. Various arguments fall under this "unfairness" umbrella, including the concern that the proposal lacks a remedy for the market worker who does a disproportionate and unfair amount of market labor that benefits the child. Perhaps an assessment of fairness should not be limited to disproportionate caregiving but should encompass disproportionate effort generally that benefits the child? If so, then not only should some caregivers not receive a remedy, but some market workers should get a remedy instead.

This criticism has appeal only if it is considered at the highest level of generality. There are two important differences between a caregiver who performs a disproportionate amount of caregiving and a market worker who performs a disproportionate amount of market labor. First, the effect of the other parent's freeloading is much more detrimental to a caregiver than a market worker. The market worker's excessive efforts will produce its own reward in terms of benefits associated with market employment. The market worker captures these gains under the status quo. If he is unmarried, the gains are his alone. If he is married, the law likely gives him control over the use and disposal of the property he earns during the marriage. ${ }^{393}$ Even at divorce, the market worker may get a larger share of the financial pie due to his excessive contributions. Some of these benefits have no comparable counterpart for the caregiver.

Second, the likely income disparity between the caregiver and market worker makes it unwise to award the market worker a financial remedy from the caregiver, even assuming the correct focus is on parental effort and not parental caregiving. Requiring the caregiver to pay the market worker money would potentially harm the child because the child and the caregiver constitute one economic unit. Assuming the market worker deserves a remedy, an appropriate remedy may be a declaratory judgment acknowledging the disproportionate and unfair parental labor benefiting the child. However, the limited usefulness of this type of remedy may sug-

392. See generally Heather Hahn et al., Urb. Inst., Research Synthesis Brief No. 5, TanF Work Reguirements and State Strategies to Fulfill Them 6 (2012), available at http://www.urban.org/UploadedPDF/412563-TANF-Work-Requirements-and-State-Strategies-to-Fulfill-Them.pdf.

393. Most states have a common law (or "separate") property regime, and not a community property regime. Even some states with a community property regime, however, allocate the control of assets (such as earnings) solely to the party that earned it. See, e.g., Leslie J. Harris, Lee E. Teitelbaum \& June R. Carbone, FAMiLY Law (4th ed. 2010). 
gest the claim itself is not a good idea, both because the market worker would have to impugn the caregiver's efforts in a way that could corrode the parents' relationship, and because there are public costs associated with resolving the claim.

Those critics who are willing to concede that a remedy should exist only for disproportionate and unfair caregiving might still argue that any financial sacrifices made by the market worker related to caregiving are relevant to an assessment of unfairness. For example, shouldn't a court consider the financial sacrifices made by a divorced father who decides to relocate with the mother and child to be closer to them so that he can participate more in childrearing? ${ }^{394}$ If courts had to consider these types of economic sacrifices, then the adjudicatory task would increase in complexity. In addition, since caregivers also make financial sacrifices to benefit their children (like living in a safer but more expensive neighborhood), it is probably fair (and best) to ignore all such contributions. Nonetheless, valuing these types of sacrifices and offsetting the caregiver's claim with their value may make sense in some cases. Acknowledging this fact does not negate the need for a caregiver remedy; it only affects its value in some cases.

Critics might also question the appropriateness of a remedy when the caregiver makes more money than the market worker. Should the other parent owe money to such a caregiver? ${ }^{395}$ There is no theoretical reason why a financially advantaged caregiver should be denied a remedy for the other parent's mooching, although the caregiver may not collect much, if anything, given the market worker's financial situation. ${ }^{396}$

Third, and finally, critics might claim that a caregiver remedy will further entrench gendered patterns of caregiving. ${ }^{397}$ Because caregivers will be entitled to an award for disproportionate and unfair caregiving, women may opt into these arrangements more, guided by cultural expectations that they are ultimately responsible for this caregiving work anyway. The caregiver remedy may also reinforce female caregiving because the higherearning party (most likely, but not always, a man) will probably want to compensate the lower-earning party to do the caregiving rather than do it himself. In contrast, the lower-earning parent may not earn enough to afford the other parent's labor, depending upon the way the caregiver remedy is calculated. In short, the remedy might contribute to the gendered patterns of caregiving labor. If so, the remedy will also reinforce

394. See Schneider, supra note 335, at 225-26.

395. Professor Ellman is not bothered by the higher-earning spouse making a claim, so long as the other party financially benefited from the higher-earning spouse's foregone opportunity. See Ellman, supra note 125, at 59.

396. Alternatively, a court may find that the appropriate remedy is simply a declaratory judgment recognizing the disproportionate and unfair labor. This is Ellman's proposal. See id. at 60-61.

397. Caregiver support payments might "foster traditional family roles, economic dependence, and the corresponding gender roles that many men and women find oppressive." Estin, supra note 85, at 799-800. 
gender inequality in the market, including the wage gap between men and women. ${ }^{398}$

The dollar value of the remedy should affect who does the caregiving, but it is hard to predict what patterns, if any, will emerge. On the one hand, if the remedy for disproportionate and unfair caregiving requires that a wage earner split with the caregiver his income earned during the period of disproportionate caregiving, then the remedy would provide a strong incentive for the higher-earning parent to caregive. Imagine a person who earns $\$ 100$ per day and has to give $\$ 50$ per day to the caregiver if he does none of the caregiving. If he instead splits the caregiving labor with her, he would not have to pay her anything, although he may earn only $\$ 50$ per day because he cannot work the same amount of hours. The cost to the market worker is the same whether he pays for caregiving or does it himself. Consequently his interest in the type of work, rather than his interest in money, should dictate his behavior. ${ }^{399}$ On the other hand, if the court only requires him to pay $\$ 20$ a day for the caregiving, he would get an economic advantage by continuing the same level of market work.

The financial incentives will also affect the caregiver's willingness to do the work. A low caregiver payment may cause caregivers to reassess their willingness to do a disproportionate share of the caregiving, and they may decide to engage in more market work instead. A lower level of compensation may also make it more likely, however, that a lower-income parent could afford to pay a higher-income parent to do a disproportionate share of the caregiving, ${ }^{400}$ although the higher-income parent may find the compensation insufficient to take the caregiving. Depending upon how the remedy is calculated, the remedy may affect the parents' choices, but the gender implications are unpredictable.

The fact that gender roles are currently in flux makes the concern about gender entrenchment less weighty. Undeniably, gender roles are changing. Women's educational progress has been steady and now their educational achievement surpasses men's. ${ }^{401}$ In 2011, seventy-one percent of mothers with children under eighteen years old were in the labor market, compared to forty-seven percent in $1975 .{ }^{402}$ More and more wo-

398. See Singer, supra note 6, at 2441 (citing Gillian K. Hadfield, Households at Work: Beyond Labor Market Policies to Remedy the Gender Gap, 82 GEO. L.J. 89, 95-96 (1993)).

399. See id. at 2454-55 (arguing that income sharing for period of time after divorce would encourage more caregiving by men).

400. The lower level of compensation could occur either from splitting the lower-paid parent's employment income or using the market value of caregiving.

401. See generally Women in America: Indicators of Social and Economic Well-Being, White House Council on Women \& GiRLs, http://www.whitehouse.gov/administration/eop/cwg/data-on-women (last visited Dec. 27, 2013).

402. Bureau of Labor Statistics, U.S. Dep't of Labor, Report 1040, WoMEN in the LABOr Force: A DATABOOK 19 tbl.7 (2013), available at http://www.bls .gov/cps/wlf-databook-2012.pdf. 
men are earning the majority of a couple's income, and these results are particularly pronounced in many African American families. ${ }^{403}$

Men are becoming more involved in the home than ever before. Fathers today spend three times as much time with children each week and twice as much time on housework as fathers did fifty years ago. ${ }^{404}$ Young fathers are also spending much more time with children than in the past. ${ }^{405}$ Men are valuing family involvement more than ever before, too. ${ }^{406}$ In one survey, only twenty-nine percent of men surveyed were "work-centric," i.e., someone who prioritized work; thirty-six percent of the men were family-centric; and thirty-five percent were dual-centric. ${ }^{407} \mathrm{~A}$ Pew Research Center survey confirms that men, ages eighteen to thirtyfour, are more focused on parenting than in the past: forty-seven percent of the men said that being a good parent is one of the most important things in their life, up from thirty-nine percent in 1997.408 Quite amazingly, a recent study of approximately 1000 fathers with white-collar jobs found that fifty-three percent agreed or strongly agreed with the statement, "If my spouse/partner made enough money for our family to live on comfortably, I would feel okay if I didn't work outside the home."409

The younger generations hold particularly strong views about the desirability of gender equality in the allocation of nonmarket work. ${ }^{410} \mathrm{Sev}$ -

403. See Sarah Jane Glynn, Citr. for Am. Progress, The New Breadwinners: 2010 UPDATE 3 (2012), available at http:///www.americanprogress.org/wp-content/uploads/issues/2012/04/pdf/breadwinners.pdf ("Among African American families, more than half (53.3 percent) of working wives earned as much or more than their husbands in 2010 . . marking a dramatic increase from 1975 when 28.7 percent were breadwinners.”). Approximately thirty-seven percent of women up to age 44 earn as much as, or more than, their husbands, and that number increases to forty-three percent for women 45 and over. Id. at 4 \& fig. 4 .

404. See Pew Research Ctr., Modern Parenthood, supra note 264, at 6, 27 (noting child care performed by fathers has increased from 2.5 hours per week in 1965 to 7.3 hours per week in 2011, while fathers also spend "more than twice as much time doing housework as they did in the 1960s"); see also Ellen GALINSKY ET al., Families \& Work Inst., Times Are Changing: Gender and Generation at Work And AT Home 14 (rev. Aug. 2011), available at http://familiesandwork.org/ site/research/reports/Times_Are_Changing.pdf (finding that fathers with paid employment spend over one hour more time with their children on daily basis than they did thirty years ago).

405. See GALINSKY ET AL., supra note 404, at 15 (reporting fathers under twenty-nine years old spend average of 4.1 hours per workday with their children in 2008 compared to 2.4 hours per workday in 1977).

406. See Kerstin Aumann et al., Families \& Work Inst., The New Male MysTIQUE 1 (2011), available at http://familiesandwork.org/site/research/reports/ newmalemystique.pdf.

407. Id. at 7 .

408. Eileen Patten \& Kim Parker, Pew Research Ctr., A Gender Reversal on Career Aspirations: Young Women Now Top Young Men in Valuing a HighPAying CAReer 5 (2012), available at http://www.pewsocialtrends.org/2012/04/ 19/a-gender-reversal-on-career-aspirations/.

409. HARrington et AL., supra note 326, at 17.

410. See id. at 11; see also Matthew N. Weinshenker, Imagining Family Roles: Parental Influences on the Expectations of Adolescents in Dual-Earner Families, in BEING TO- 
enty percent of boys and sixty-eight percent of girls expect to share housework equally, and seventy-eight percent of boys and sixty-six percent of girls expect to share caregiving equally. ${ }^{411}$ On the job front, equal numbers of both male and female millennials want jobs with great responsibility, and young women's views do not vary depending upon whether they are mothers. ${ }^{412}$ Another survey found that sixty-six percent of women ages eighteen to thirty-four rate having a career high on their list of life priorities, while only fifty-nine percent of men do. ${ }^{413}$

Society is increasingly tolerant of departures from classic gender roles. ${ }^{414}$ In 2010, seventy-one percent of Americans surveyed thought that a marriage was more satisfying if both spouses had labor-market jobs, as opposed to a marriage in which the couple had traditional gender rolesup from fifty-eight percent in 2002. ${ }^{415}$ Most people favor gender equality, including the ability of women to work outside the home. ${ }^{416}$ Most men and women believe that equal participation in childrearing is important. ${ }^{417}$

Of course, there is still much work to be done to eliminate gender roles in the market and home spheres. Children accept a woman's labor market participation much easier than they accept a father's role as the caregiver. ${ }^{418}$ High school students differ by gender regarding their expectations of who will take time off from work when they get older, marry, and have children, with boys and girls both pointing to the girls. ${ }^{419}$ Even chil-

gether, Working Apart: Dual-Career Families and the Work-Life Balance 365, 374 tbl.14.1 (Barbara Schneider \& Linda J. Waite eds., 2005).

411. Weinshenker, supra note 410, at 374 tbl.14.1.

412. See Galinsky et Al., supra note 404, at 1-2.

413. Patten \& Parker, supra note 408, at 1-2.

414. See, e.g., Scott Coltrane, Family Man: Fatherhood, Housework, and Gender EQuity 201-06 (1996).

415. Pew Research Ctr., Global Attitudes Project, Gender Equality Universally Embraced, but Inequalities Acknowledged: Men's Lives Often Seen as BetTer 8 (2010), available at http://www.pewglobal.org/2010/07/01/genderequality/.

416. Id. at 1-2.

417. See Harrington Et Al., supra note 326, at 2, 23; Milkie et al., supra note 296, at 36 .

418. See Stefanie M. Sinno \& Melanie Killen, Moms at Work and Dads at Home: Children's Evaluations of Parental Roles, 13 Applied Develop. Sci. 16, 22, 25 (2009); cf. Christine Schuette \& Melanie Killen, Children's Evaluations of Gender-Stereotypic Household Activities in the Family Context, 20 Early Educ. \& Develop. 693, 707 (2009) (“[C]hildren were more stereotypic and inflexible about male-stereotypic activities than about female stereotypic activities."); see also Ellen A. Greever, Patricia Austin \& Karyn Welhousen, William's Doll Revisited, 77 Language Arts 324, 326-27 (2000) ("Children who are influenced by adults to challenge gender stereotypes are more likely to be aware of that influence than those who are influenced by adults to accept gender stereotypes.").

419. See generally Ellen Galinsky et al., Families \& Work Inst., Youth And Employment: Today's Students Tomorrow's Workforce: Summary and DiscusSION GuIDE (2003), available at http://familiesandwork.org/site/research/summa ry/yande.pdf. 
dren's letters to Santa still show that girls, but not boys, want the toys that are related to domestic work. ${ }^{420}$ This is not surprising given that gender stereotypes still permeate the media. ${ }^{421}$ Nonetheless, society is headed in the right direction, and this fact makes any concern about entrenching gender roles less pressing because the gender roles today are more fluid.

It is impossible to predict accurately whether a new gender-neutral caregiver remedy would accelerate this change. ${ }^{422}$ Since a caregiver remedy would make caregiving costs a joint responsibility of both parents, it is possible that the gender-linked roles of caregiver and market worker would further weaken. As Ann Crittenden stated: " $[\mathrm{M}]$ en are more likely to share the increasing responsibilities involved in raising children if mothers have more leverage to convince fathers that the children come first." 423

More predictable is the remedy's likely effect on freeloading, which is largely done by men to women. It should reduce freeloading, regardless of which parent does a disproportionate amount of the caregiving. For this effect, this end-of-the-relationship remedy would have to affect behavior during the relationship. Scholars have raised legitimate questions about the efficacy of an end-of-the-relationship remedy on relationship behavior. Professor Carl Schneider once explained that the law of alimony was not an effective hortatory tool-i.e., to exhort couples to act fairly in their allocation and remuneration of child-related work-because people often "don't know what the law's incentives are," or if they know, they never think it will apply to them because they do not imagine getting divorced. ${ }^{424}$ Nor do people investigate the law of divorce before marriage because that suggests they are not confident in the success of their own marriage. ${ }^{425}$ Professor Schneider also suggested that if a remedy were to have any possible effect on marital behavior, then a simple remedy was

420. See Carol J. Auster \& Claire S. Mansbach, The Gender Marketing of Toys: An Analysis of Color and Type of Toy on the Disney Store Website, 67 SEx RoLEs 375, 377 (2012).

421. See id. at 386 (finding that online Disney Store perpetuates gender stereotypes regarding domestic work); James Gentry \& Robert Harrison, Is Advertising a Barrier to Male Movement Toward Gender Change?, 10 Marketing Theory 74, 89 (2010) (finding commercials aimed at children perpetuate gender stereotypes; specifically, only 7 of 225 commercials in one study showed father and no commercial showed father in nurturing role); Kimberly A. Powell \& Lori Abels, Sex-Role Stereotypes in TV Programs Aimed at the Preschool Audience: An Analysis of Teletubbies and Barney \& Friends, 25 Women \& Language 14 (2002) (finding gender stereotypes infiltrate children's television shows, such as Barney $\mathcal{E}$ Friends and Teletubbies).

422. Susan Okin argued, "[A]ny just and fair solution to the urgent problem of women's and children's vulnerability must encourage and facilitate the equal sharing by men and women of paid and unpaid work, of productive and reproductive labor." Okin, supra note 179, at 171.

423. Crittenden, supra note 54, at 130.

424. Schneider, supra note 335, at 205-06.

425. See id. at 207. 
required, so that people could understand exactly what the remedy might be. ${ }^{426}$

Now Professor Schneider's admonition has less force for the caregiver payments proposed here: this remedy should actually minimize the freeloading that occurs because the proposed remedy is simple. "Give care or share, or else the judge will make it fair," is an easy slogan to popularize. This remedy, therefore, might assuage Professor Schneider's concerns, assuming of course that individuals do not need to know the precise amount of the remedy, or understand the way it would be calculated. In addition, the remedy's universality will make it common. The caregiver remedy will be like child support in its familiarity. Since most parents, regardless of marital status, experience difficulty in their romantic relationship upon the transition to parenthood, ${ }^{427}$ the potential applicability of an end-ofthe-relationship caregiver remedy will be salient almost immediately; the remedy, therefore, should affect the parties' behavior during their parenting relationship.

In the end, it is hard to believe that providing a remedy for the current situation-a situation in which many parents (mostly men) freeload off of the other parent (mostly women)-is worse for women than the status quo. Of course, there is nothing inherently wrong with a commitment to caregiving or even to more women caregiving than men. It is only the social ramifications of the gender imbalance that are problematic. It seems misguided to blame a caregiver payment for the broader social inequalities between men and women. Nothing about a caregiver payment would stop simultaneous work on other social policies that might equalize caregiving by men and women or further reduce the disadvantages associated with caregiving. Scholars have noted the need for such things as equal pay, an end to job segregation, a flexible workday, paid maternity leave, affordable and safe child care, and paid family leave to care for sick family members. ${ }^{428}$ Improvements in all of these areas are necessary to see true and sustained social change around gender roles. The caregiver payment has the advantage of making all parents invested enough in the act of caregiving that more parents might encourage employers and the government to accommodate families' real needs.

426. See id. at 208. He believed Professor Ellman's complex remedy did not qualify. See id.

427. See Erika Lawrence et al., Marital Satisfaction Across the Transition to Parenthood, 22 J. Fam. Psych. 41, 47 (2008); Philip A. Cowan \& Carolyn Pape Cowan, Changes in Marriage During the Transition to Parenthood: Must We Blame the Baby?, in The Transition to Parenthood: Current Theory and Research 118-19 (Gerlad Y. Michaels \& Wendy A. Goldberg eds., 1988).

428. See Joan C. Williams, Reshaping the Work-Family Debate: Why Men and Class Matter 35-36, 42 (2010); Maxine Eichner, Families, Human Dignity, and State Support for Caretaking: Why the United States' Failure to Ameliorate the Work-Family Conflict Is a Dereliction of the Government's Basic Responsibilities, 88 N.C. L. Rev. 1593, 1624-25 (2010). 


\section{Conclusion}

The law should have a remedy to redress disproportionate and unfair caregiving. The law should recognize that freeloading off of a caregiver is not acceptable, regardless of whether the caregiver is married, unmarried, or divorced. The judge hearing the claim should assess unfairness by examining such issues as the amount of leisure time each parent enjoys, the allocation of market and non-market work between the parents, the extent to which the caregiver shares the market worker's financial resources, and the parents' agreement, if any, about caregiving and sharing. If a court determines that a caregiver has borne a disproportionate and unfair allocation of the caregiving, the court should provide compensation. The amount awarded should depend upon the most appropriate compensatory alimony theory (gain, loss, or contribution), which in turn should be influenced by the facts: the parties' broader relationship, the parties' agreement, the ability to prove damages under a particular theory, and the relevance of fault in the jurisdiction. The complexity and highly fact-specific nature of the task suggest judicial discretion is essential to afford caregivers justice. Practically, affording all caregivers access to a remedy for their disproportionate and unfair caregiving requires the adoption of a standard: courts should award a just amount in light of the obligation to give care or share. Adjudication under such a standard is also the best way to obtain empirical information about fair outcomes so that the law can continue to move forward. 